Environmental Management Assessment of the

National Institute for Petroleum and Energy Research

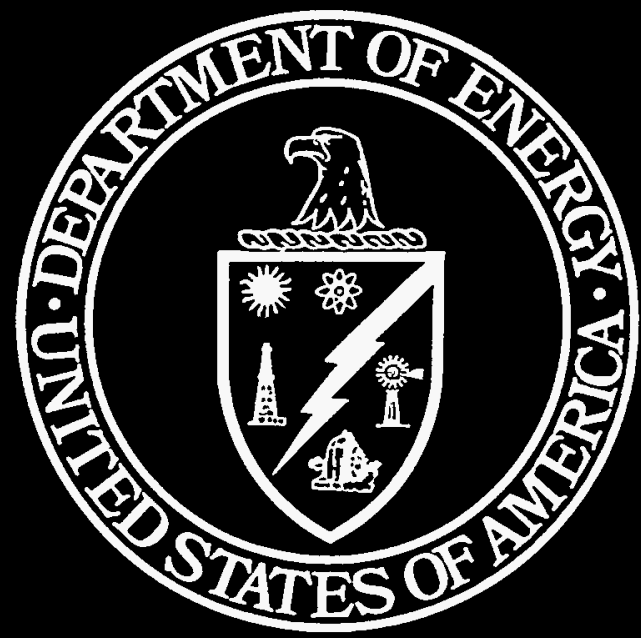

U.S. Department of Energy Office of Environmental Audit

August 1994 
This report has been reproduced directly from the best available copy.

Available to DOE and DOE contractors from the Office of Scientific and Technical Information, P.O. Box 62, Oak Ridge, TN 37831: prices available from (615) 576-8401.

Available to the public from the U.S. Department of Commerce, Technology Administration, National Technical Information Service, Springfield, VA 22161 (703) $487-4650$.

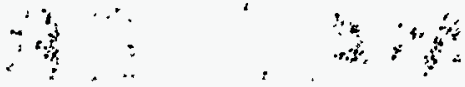

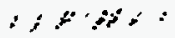

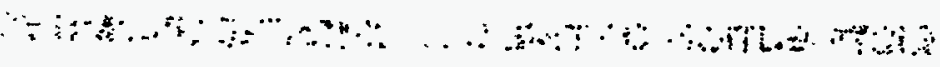




\section{Environmental Management Assessment of the \\ National Institute for Petroleum and Energy Research}

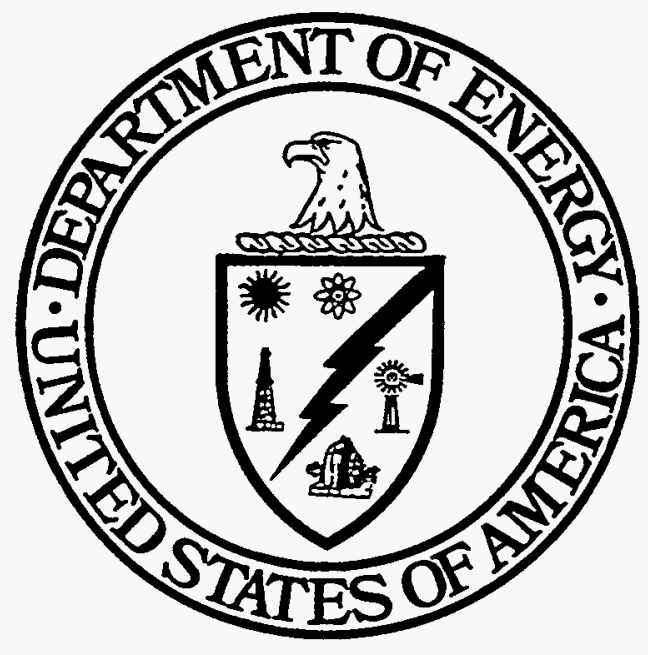

\section{U.S. Department of Energy}

Office of Environmental Audit

Washington; DC 20585

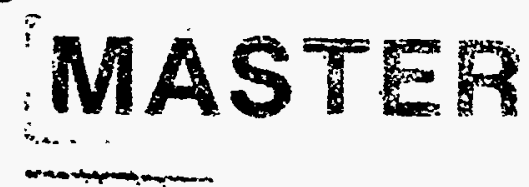

August 1994

DISTRIBUTION OF THIS DOCUMENT IS UNLIMITED 



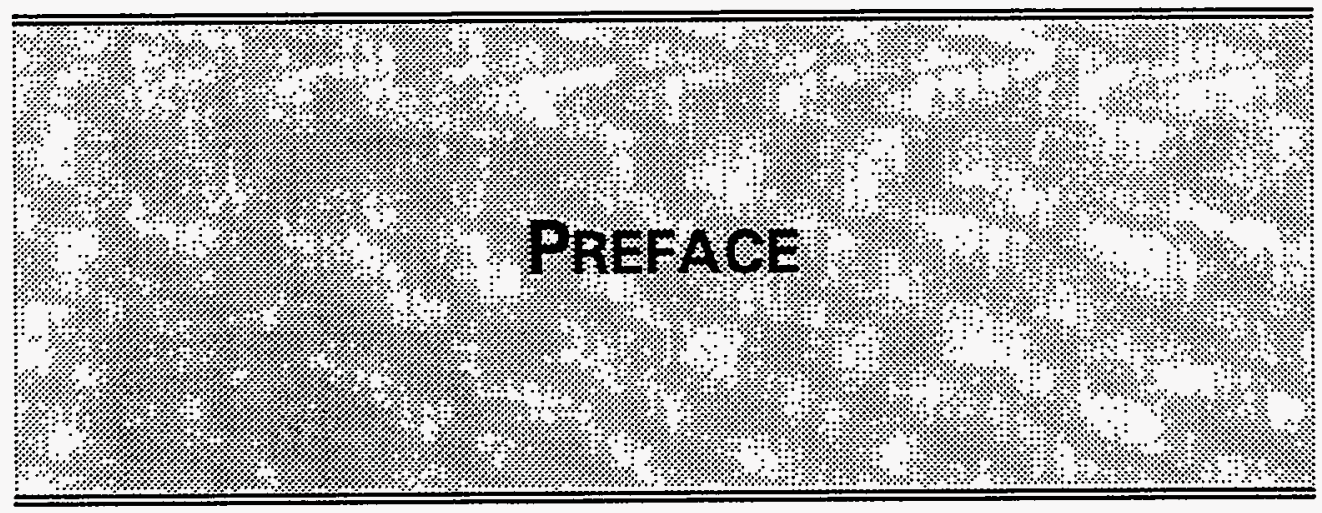


Page intentionally blank 


\title{
Preface
}

\section{U.S. Department of Energy}

\author{
Environmental Management Assessment \\ of the National Institute for Petroleum and Energy Research
}

The Secretary of Energy's July 20, 1993, Environment, Safety and Health Policy establishes daily excellence in protection of the worker, the public, and the environment as the hallmark and highest priority of all DOE activities. That policy also calls for a proactive program of continuous improvement to move the Department beyond minimal compliance with laws and regulations. To further that policy the Office of Environment, Safety and Health (EH) has established a program to conduct environmental assessments of DOE programs and operating facilities. This program, which is within the Office of Environmental Audit (EH-24), is part of the oversight responsibilities within DOE. The ultimate goal of this program is enhancement of environmental protection and minimization of risk to public health and the environment through systematic and periodic evaluations of the Department's environmental programs within line organizations.

Through its environmental evaluation program, which results in measurable goals with milestones, EH-24 is committed to helping establish DOE as a model of responsible environmental stewardship. In addition, this program will serve to reinforce the Secretary's goal of building on the ongoing efforts to attain and maintain compliance in cooperation with regulatory authorities and other stakeholders.

This document contains the findings identified during the environmental management assessment of the National Institute for Petroleum and Energy Research, conducted August 15-26, 1994. The objective of the assessment was to advise the Secretary of Energy through the Assistant Secretary for Environment, Safety and Health of the adequacy of management systems to ensure compliance with Federal, state, local, and DOE environmental requirements, and to evaluate application of proactive management practices. The scope of the assessment was comprehensive and covered all areas of environmental management.

August 1994

Washington, DC 
Page intentionally blank 


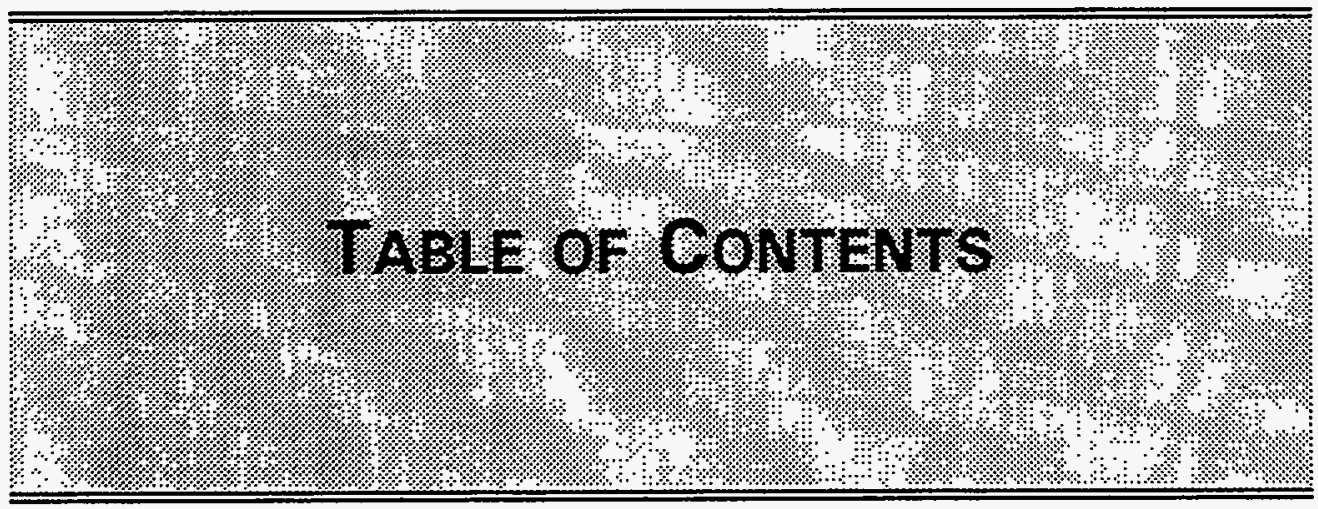


Page intentionally blank 
PREFACE $\ldots \ldots \ldots \ldots \ldots \ldots \ldots \ldots \ldots \ldots \ldots \ldots \ldots \ldots \ldots \ldots \ldots \ldots \ldots$

EXECUTIVE SUMMARY $\ldots \ldots \ldots \ldots \ldots \ldots \ldots \ldots \ldots \ldots \ldots \ldots \ldots \ldots$

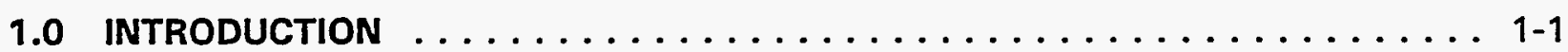

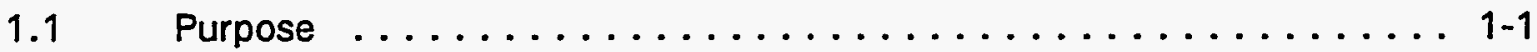

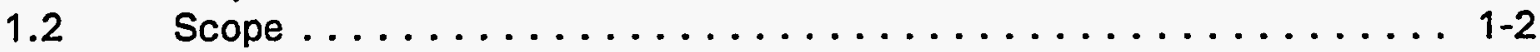

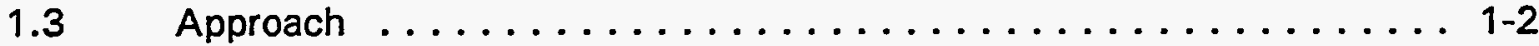

1.4 Background and Project Description . . . . . . . . . . . . . 1-4

1.5 Environmental Management Programs and Organizations . . . . . . . 1-4

2.0 SUMMARY OF ENVIRONMENTAL MANAGEMENT ASSESSMENT RESULTS . . . 2-1

2.1 Findings Summary $\ldots \ldots \ldots \ldots \ldots \ldots \ldots \ldots \ldots \ldots \ldots \ldots \ldots \ldots$

$2.2 \quad$ Key Findings $\ldots \ldots \ldots \ldots \ldots \ldots \ldots \ldots \ldots \ldots \ldots \ldots \ldots \ldots$

3.0 ENVIRONMENTAL OVERVIEWS AND ASSESSMENT FINDINGS $\ldots \ldots \ldots$

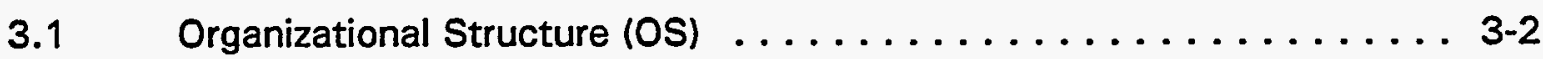

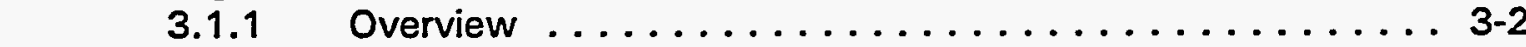

3.2 Environmental Commitment (EC) $\ldots \ldots \ldots \ldots \ldots \ldots \ldots \ldots \ldots \ldots$

3.2.1 Overview ........

3.3 Environmental Protection Programs (EP) $\ldots \ldots \ldots \ldots \ldots \ldots \ldots \ldots$. . . . .

3.3.1 Overview ......................... 3-7

3.4 Formality of Environmental Programs (FP) $\ldots \ldots \ldots \ldots \ldots \ldots \ldots$

3.4 .1 Overview ....................... 3-13

3.4 .2 Finding $\ldots \ldots \ldots \ldots \ldots \ldots \ldots \ldots \ldots \ldots \ldots \ldots \ldots$

3.5 Internal and External Communication (IC) $\ldots \ldots \ldots \ldots \ldots \ldots \ldots$

3.5 .1 Overview ......................... 3-19

3.6 Staff Resources, Training, and Development (SR) . . . . . . . . . 3-22

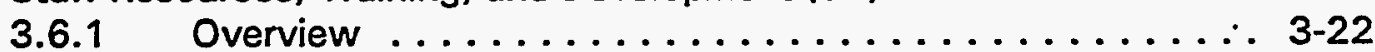

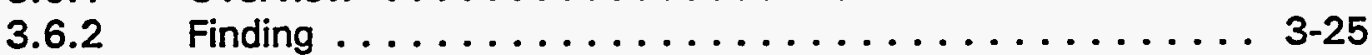

3.7 Program Evaluation, Reporting, and Corrective Action (PE) . . . . . 3-26

3.7.1 Overview ......................... 3-26

3.7 .2 Finding ...................... 3 .30

3.8 Environmental Planning and Risk Management (RM) . . . . . . . 3-32

3.8 .1 Overview ........................ 3 .32

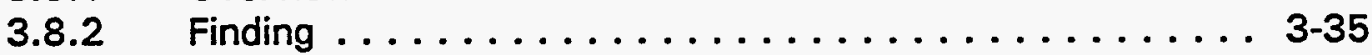

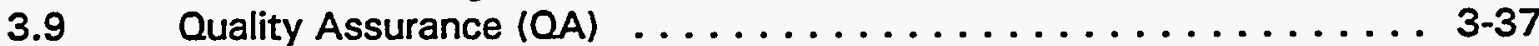

3.9 .1 Overview .......................... 37 


\section{LIST OF FIGURES}

Figure $1-1 \quad$ NIPER Location Map $\ldots \ldots \ldots \ldots \ldots \ldots \ldots \ldots \ldots \ldots$

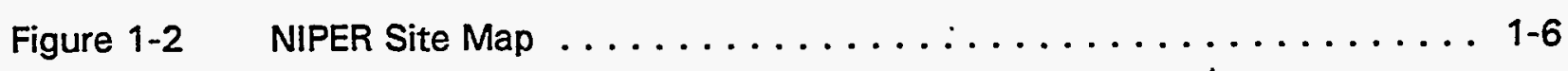

Figure $1-3 \quad$ Office of Fossil Energy $\ldots \ldots \ldots \ldots \ldots \ldots \ldots \ldots \ldots$

Figure 1-4 Bartlesville Project Office $\ldots \ldots \ldots \ldots \ldots \ldots \ldots \ldots \ldots$

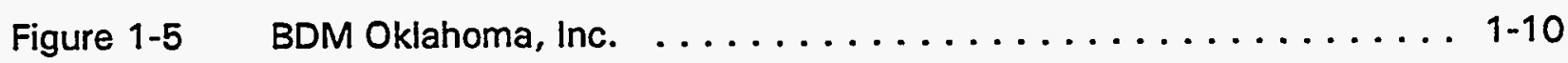

Figure 1-6 BDM Oklahoma, Inc., Environmental, Safety \&

Health Department $\ldots \ldots \ldots \ldots \ldots \ldots \ldots$ 1-11

\section{LIST OF APPENDICES}

Appendix A Biographical Sketches of the Assessment Team $\ldots \ldots \ldots \ldots \ldots$. . .

Appendix B Assessment Plan ....................... B-1

Appendix $\mathrm{C} \quad$ Schedule of Onsite Activities . . . . . . . . . . . . . . C-1

Appendix D Site Documents the Assessment Team Reviewed ........... D-1

Appendix E Contacts/interviews the Assessment Team Conducted . . . . . . . . E-1

Appendix $F \quad$ Environmental Management Requirements
and Guidelines $\ldots \ldots \ldots \ldots \ldots \ldots \ldots \ldots \ldots \ldots \ldots$

Appendix $\mathrm{G} \quad$ Glossary of Acronyms and Abbreviations $\ldots \ldots \ldots \ldots \ldots \ldots$ 


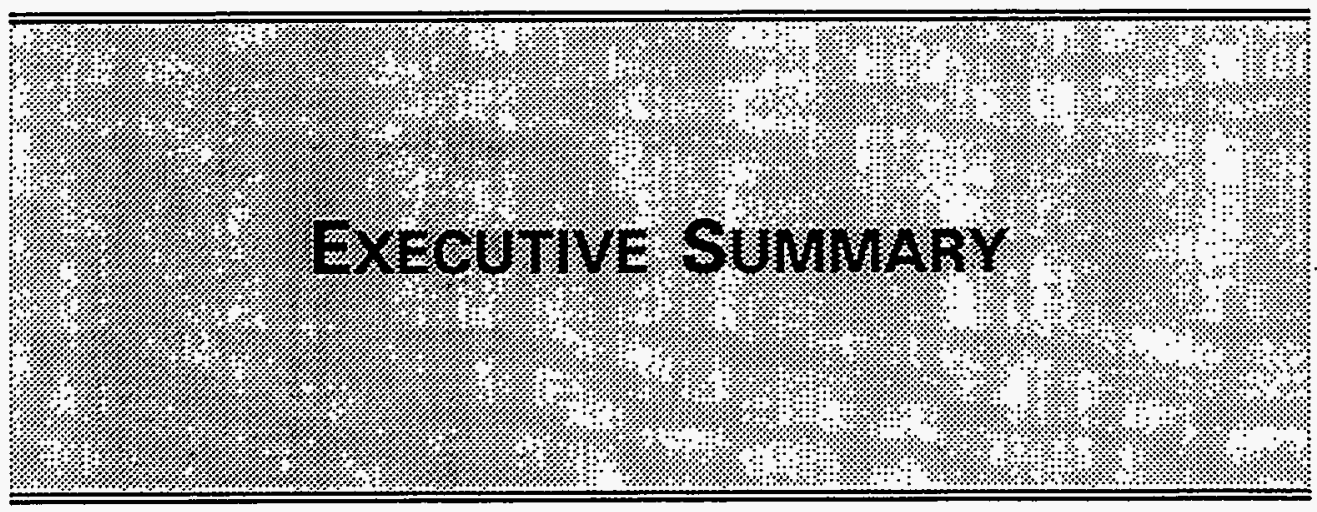


Page intentionally blank

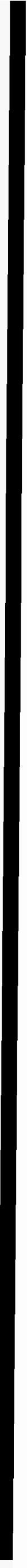




\section{EXECUTIVE SUMMARY}

This report documents the results of the environmental management assessment of the National Institute for Petroleum and Energy Research (NIPER), located in Bartlesville, Oklahoma. The assessment was conducted August 15-26,1994, by the DOE Office of Environmental Audit (EH-24), located within the Office of Environment, Safety and Health.

The assessment included reviews of documents and reports, as well as inspections and observations of selected facilities and operations. Further, the team conducted interviews with management and staff from the Bartlesville Project Office (BPO), the Office of Fossil Energy (FE), the Pittsburgh Energy Technology Center (PETC), state and local regulatory agencies, and BDM Oklahoma (BDM-OK), which is the management and operating (M\&O) contractor for NIPER.

Because of the transition from a cooperative agreement to an M\&O contract in January 1994, the scope of the assessment was to evaluate (1) the effectiveness of BDM-OK management systems being developed and BPO systems in place and under development to address environmental requirements; (2) the status of compliance with DOE Orders, guidance, and directives; and (3) conformance with accepted industry management practices. An environmental management assessment was deemed appropriate at this time in order to identify any systems modifications that would provide enhanced effectiveness of the management systems currently under development.

The assessment team identified four findings. Although no key findings were identified, the team finds that there is one significant observation regarding weakness in BPO environmental oversight. BPO currently conducts most of its environmental oversight activities informally. There is a lack of formality associated with the planning and implementation of BPO environmental management systems that does not permit proper analysis of pertinent environmental information. Formality is an essential component of effective environmental management systems that will promote sustained excellence and continuous improvement in environmental operations. This situation, however, has not currently resulted in the manifestation of new environmental compliance issues because of $\mathrm{BPO}$ and BDM-OK's effective relationship, which is providing momentum toward the accomplishment of environmental goals.

The assessment team also identified two strengths in the site's environmental management programs. For the purposes of this report, strengths are attributes that have promoted environmental management systems' effectiveness within the facility. The strengths are discussed below.

\section{Strength}

- BDM-OK Environmental Personnel Dedication. BDM-OK environmental management and staff have demonstrated outstanding dedication to the accomplishment of onsite environmental protection. The high level of commitment to achieving environmental excellence is a key component to the development of successful environmental operations at NIPER.

Overall, NIPER has been exerting extensive effort during the past year toward the establishment of effective management systems to support its environmental programs. 
FE and BPO's oversight of the former operator did not result in effective management of NIPER environmental operations, as evidenced by the more than 150 environmental issues identified during the commencement of the new M\&O operations. These issues, however, are currently being addressed through the cooperative efforts of BPO and BDM-OK concurrently with the development of appropriate environmental management systems.

Increased formality of BPO's environmental oversight would be expected to enhance the overall effectiveness of the management systems being developed and now in place. BDM-OK has demonstrated a work ethic that embraces the concepts of environmental excellence discussed in the Secretary's ES\&H policy statement. Further, BPO and BDM-OK personnel have been cooperative and responsive in their approach to address findings that can be quickly corrected. They have also indicated their intention to plan for longer-term corrective action in response to the findings contained herein. These findings represent environmental issues, which, if appropriately addressed, will reduce the potential for liabilities associated with ongoing environmental activities at NIPER. 


\section{Section 1.0}

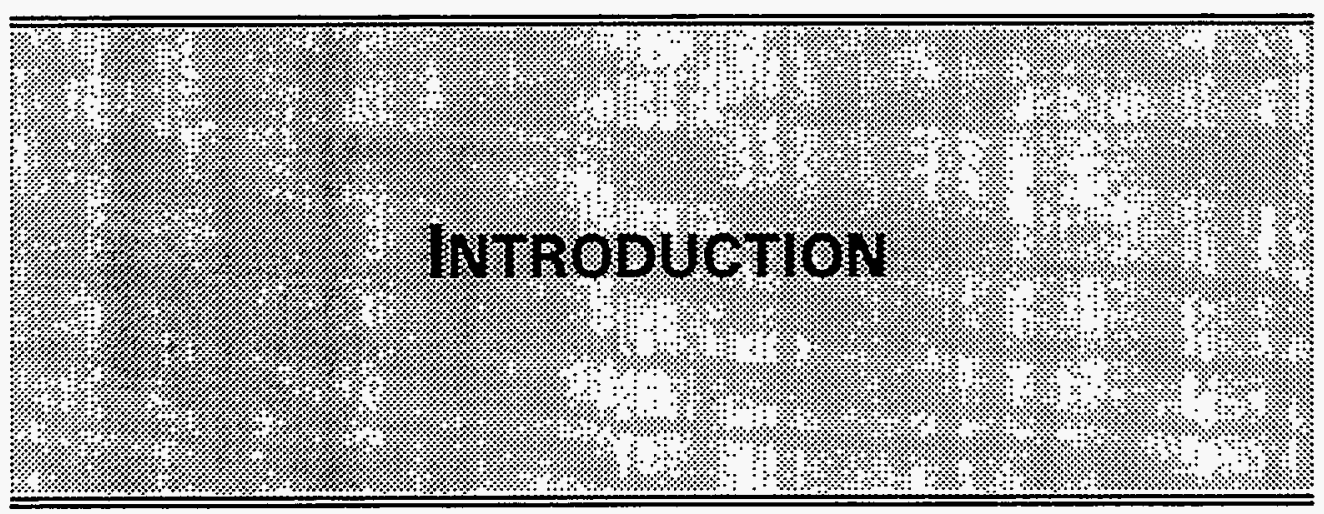


Page intentionally blank 
This report documents the results of the environmental management assessment of the National Institute for Petroleum and Energy Research (NIPER), located in Bartlesville, Oklahoma. The onsite portion of the assessment was conducted August 15-26, 1994, by the Office of Environmental Audit (EH-24).

DOE 5482.1B, "Environment, Safety and Health Appraisal Program," establishes the mission of EH-24, which is to provide comprehensive, independent oversight of DOE complex-wide environmental programs on behalf of the Secretary of Energy. The ultimate goal of EH-24 is to enhance environmental protection and minimize risk to public health and the environment. EH-24 accomplishes its mission by conducting systematic and periodic evaluations of the Department's environmental programs within line organizations and by using supplemental activities that strengthen self-assessment and oversight functions within program, field, and contractor organizations.

These evaluations function as a vehicle to apprise the Secretary and program managers of the current status and vulnerabilities of Departmental environmental activities and environmental management systems. Several types of evaluations are conducted, including the following:

- environmental management assessments;

- comprehensive baseline environmental audits;

- routine environmental audits; and

- $\quad$ special issue reviews.

The purpose, scope, and approach of the assessment are described below.

\section{$1.1 \quad$ PURPOSE}

The purpose of this assessment is to provide the Secretary of Energy, through the Assistant Secretary for Environment, Safety and Health, with concise information pertaining to the following areas:

- adequacy of environmental management programs and organizations;

- compliance with DOE Orders and DOE environmental policies that address environmental management programs;

- DOE vulnerabilities and liabilities associated with environmental management practices;

- $\quad$ adherence to best management and accepted industry practices pertaining to environmental management programs; 
- progress and effectiveness of environmental corrective actions resulting from the 1992 Tiger Team Assessment; and

- noteworthy environmental management practices.

The information gathered during this assessment and embodied in this report will assist DOE in determining patterns and trends in environmental deficiencies and strengths. The DOE Office of Fossil Energy (FE); the Bartlesville Project Office (BPO); and the NIPER management and operating contractor, known as BDM-Oklahoma (BDM-OK); are expected to make full use of this information to develop corrective actions, make appropriate modifications to specific programs to prevent recurrence, and implement lessons-learned programs to ensure broad applications to other operations, programs, and facilities.

\section{2 \\ SCOPE}

The scope of this assessment included the eight disciplines of environmental management, which are described in the Protocols for Conducting Environmental Management Assessments (DOE/EH-0326, June 1993), plus quality assurance. The management disciplines were organizational structure (OS); environmental commitment (EC); environmental protection programs (EP); formality of environmental programs (FP); internal and external communication (IC); staff resources, training, and development (SR); program evaluation, reporting, and corrective action (PE); and environmental planning and risk management (RM).

Environmental management was evaluated within and between BPO and BDM-OK. Additional consideration was given to reporting and oversight relationships with $F E$, the responsible DOE Headquarters program office, and the Pittsburgh Energy Technology Center (PETC).

\subsection{APPROACH}

This assessment was designed to evaluate the effectiveness of management systems associated with NIPER environmental operations and programs.

The assessment followed accepted auditing techniques and was guided by implementation of procedures and programs cited in the DOE Environmental Audit Program Guidance (January 1994 draft final), the Protocols for Conducting Environmental Management Assessments (DOE/EH-0326, June 1993), and Performance Objectives and Criteria for Conducting DOE Environmental Audits (DOE/EH-0358, January 1994). The assessment was conducted by a team of professionals managed by a DOE Headquarters Team Leader from EH-24 and a Group Coordinator and five management systems specialists from Arthur D. Little, Inc. (ADL). The names, areas of responsibility, affiliations, and biographical sketches of the team members are provided in Appendix A.

During the planning phase a memorandum, dated May 1, 1994, was sent to BPO announcing the assessment and requesting information about NIPER facilities and its environmental programs in general. A pre-assessment site visit was conducted June 29-30, 1994, by the DOE Team Leader and the Group Coordinator from ADL. NIPER's response to the information request memorandum, combined with the pre-assessment site visit, formed the basis for the Assessment Plan (see Appendix B), which was transmitted on July 26, 1994, and included a preliminary onsite agenda. Once onsite, the assessment team modified the 
preliminary agenda as more information was obtained and additional areas of interest were identified. Appendix $\mathrm{C}$ provides the final schedule of onsite activities.

Because certain DOE Headquarters offices impact the effectiveness of environmental management systems associated with NIPER's environmental operations and programs, interviews with personnel from FE were conducted before the onsite portion of the assessment.

Onsite assessment activities were conducted August 15-26, 1994, and included interviews in Bartlesville, Oklahoma, with the staff and management of BPO and BDM-OK; interviews with management at FE and with state and local regulatory officials; document reviews, including reviews of previous audit reports; and selected field inspections to support a programmatic assessment. The assessment team conducted daily debriefs that were attended by BPO and BDM-OK personnel, and officials from state and local regulatory agencies. A list of site documents reviewed and interviews conducted is provided in Appendices $D$ and $E$ respectively. Using these sources of information the assessment team developed overviews and findings, which are discussed in Sections 2.0 and 3.0 of this report.

During the assessment, the environmental management specialists, except for the management specialist in the environmental protection programs (EP) discipline, broadly reviewed the environmental activities applicable to their disciplines horizontally across management lines rather than focusing only on certain environmental programs. The EP specialist, however, evaluated the activities of a representative number of environmental programs in a more technical manner. This latter approach required this specialist to look at the environmental activities of each selected environmental program or activity vertically from upper management down to the operator level. The result was more intense document reviews and interviews within specific environmental programs and activities than were performed by the other management specialists on the team. Further, the EP management specialist devoted a small portion of the efforts toward field investigation. The level of field investigation effort was, however, less than would normally be conducted by specialists who would cover functional environmental disciplines (e.g. air quality, waste management) during baseline environmental audits or appraisals. This approach provided sufficient specific technical evidence supporting the degree of effectiveness of the environmental management systems.

Findings the assessment team identified are conditions that, in the team's judgment, might not satisfy DOE Orders, agreements with regulatory agencies, internal DOE or contractor environmental policies and procedures, regulatory agency or DOE guidance, or accepted industry practices that relate to environmental management systems.

The findings and overviews detailed in Section 3.0 are organized into the eight environmental management disciplines, as mentioned in Section 1.2. Each finding is organized into three sections: the performance objective, the finding statement, and a discussion of the facts and observations supporting the finding. The performance objectives specify the particular standards against which the finding is being evaluated. The findings are not arranged in order of relative significance.

When documenting environmental management concerns in the report, the concern is called a "Finding." No other terms are used. The basis for environmental management findings is usually associated with voluntary standards or best management practices that are designed 
to achieve environmental excellence, thus going beyond the minimum standard for environmental compliance. Management findings may, however, include discussions supported by compliance issues. When a corrective action plan with schedules and milestones is developed, each management finding should be addressed as though it were at least as important as, if not more important than, a specific compliance- related issue. Using this method is important because the management principles, effectively developed and employed, can ensure that line organizations across entire facilities achieve sustained overall excellence, rather than individual compliance victories, in environmental performance.

\section{$1.4 \quad$ BACKGROUND AND PROJECT DESCRIPTION}

The current NIPER mission is to conduct and contract research and specialized technical services for the oil and gas exploration and production industry; for chemical, refining, and petrochemical companies; and for the transportation and industrial sector. NIPER also seeks to lend support to Government programs in these areas.

Founded in 1918 by the U.S. Bureau of Mines, the facility now known as NIPER has undergone several name changes: the Bartlesville Petroleum Experiment Station, 1918-1959; the Bartlesville Petroleum Research Center, 1959-1971; The Bartlesville Energy Research Center, 1971-1978; the Bartlesville Energy Technology Center, 1978-1983; and the National Institute for Petroleum and Energy Research.

BPO is located onsite at NIPER and provides day-to-day oversight of NIPER's environmental operations. The site currently employs approximately 240 people, of whom 25 are Federal employees.

NIPER has been managed and operated by BDM-OK since January 1, 1994. It was previously managed and operated by Illinois Institute of Technology Research Institute (IITRI).

The facility is located in the City of Bartlesville (Washington County) in northeastern Oklahoma. Bartlesville is approximately 50 miles north of Tulsa (see Figure 1-1). The 17-acre site is bordered on the west by Penn Street and on the south by Cudahy Street. Single-family homes are adjacent to NIPER and border the facility on all sides (see Figure 1-2).

\section{5 \\ ENVIRONMENTAL PROGRAMS AND ORGANIZATIONS}

FE is responsible for research and development programs involving fossil fuels-coal, petroleum, and natural gas. The objective of the program is to provide the general technology and knowledge base that the private sector can use to complete development of advanced processes and energy systems and initiate their commercialization. In support of this objective some of the FE functions include petroleum and gas research, exploratory development, and limited proof-of-concept testing. BPO/NIPER receives direct oversight and support from three FE organizations: the Office of Self-assessment (FE-6), the Office of the Deputy Assistant Secretary for Gas and Petroleum Technology (FE-30), and PETC.

The FE organization chart appears in Figure 1-3. FE has both landlord and lead Cognizant Secretarial Office responsibility over BPO/NIPER. FE is the sole DOE Cognizant Secretarial Office providing funding for NIPER operations and environmental activities. On April 10, 1992, the Assistant Secretary for Fossil Energy (FE-1) issued a directive that designated ES\&H roles and responsibilities for BPO/NIPER operations. 


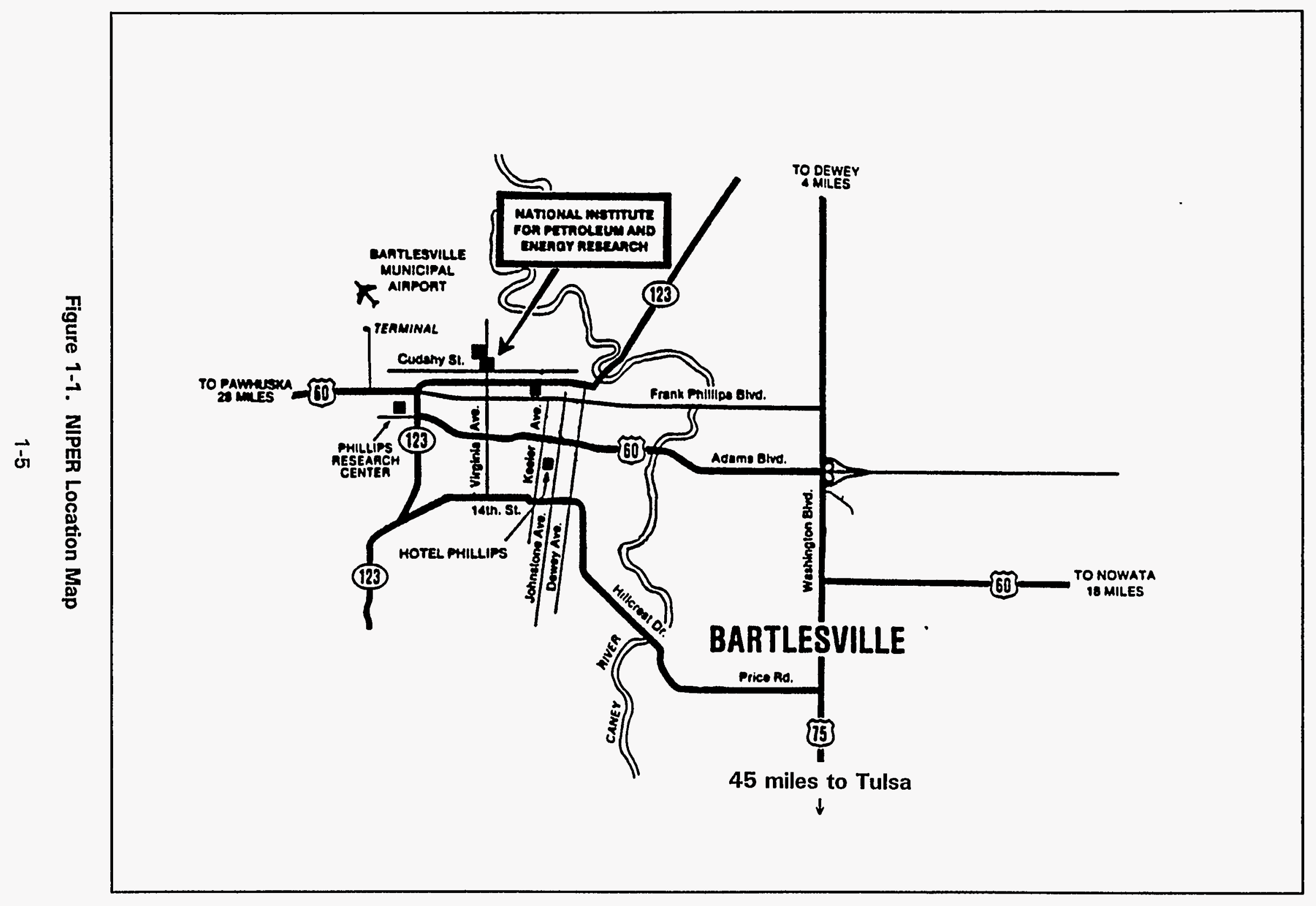




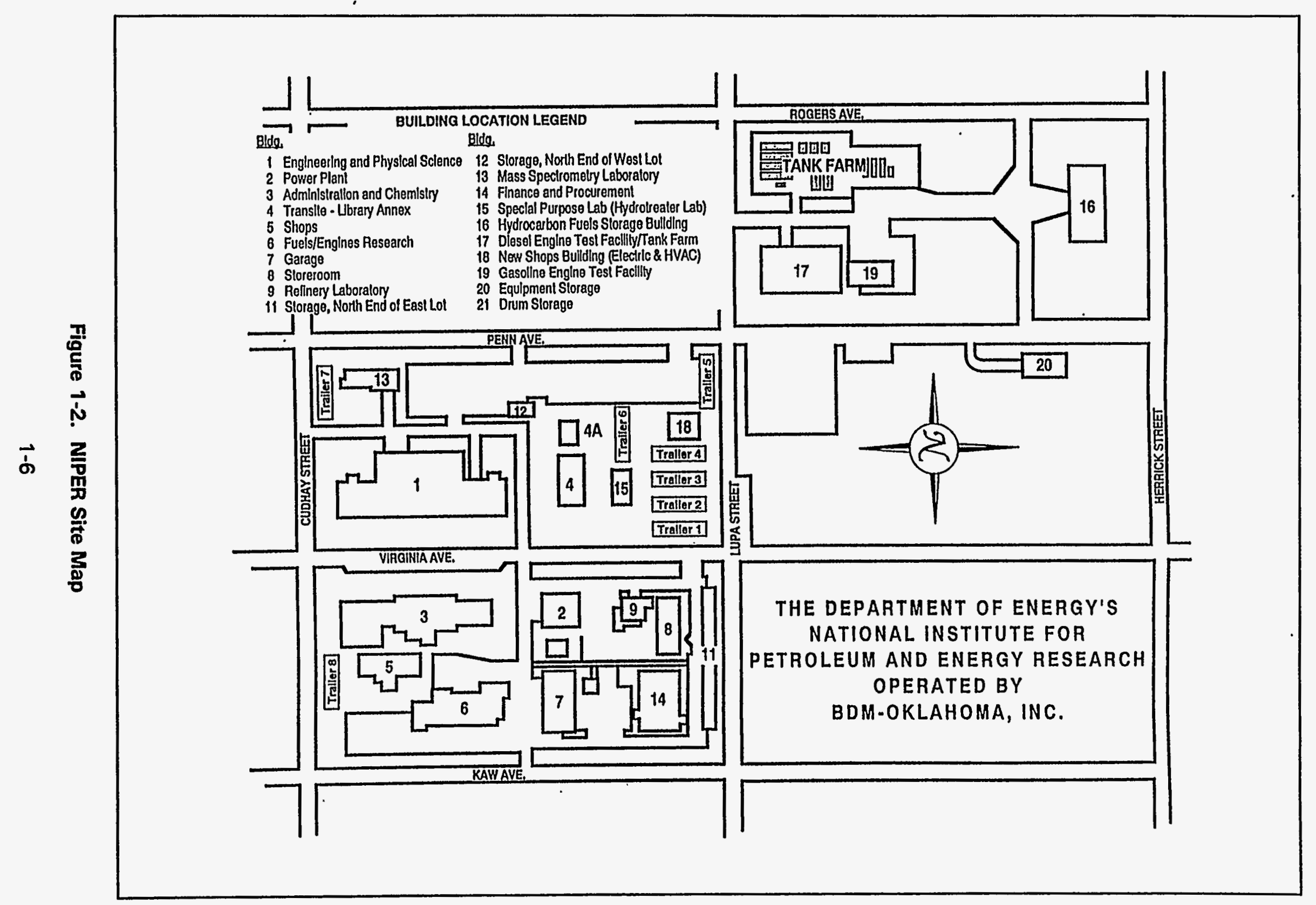




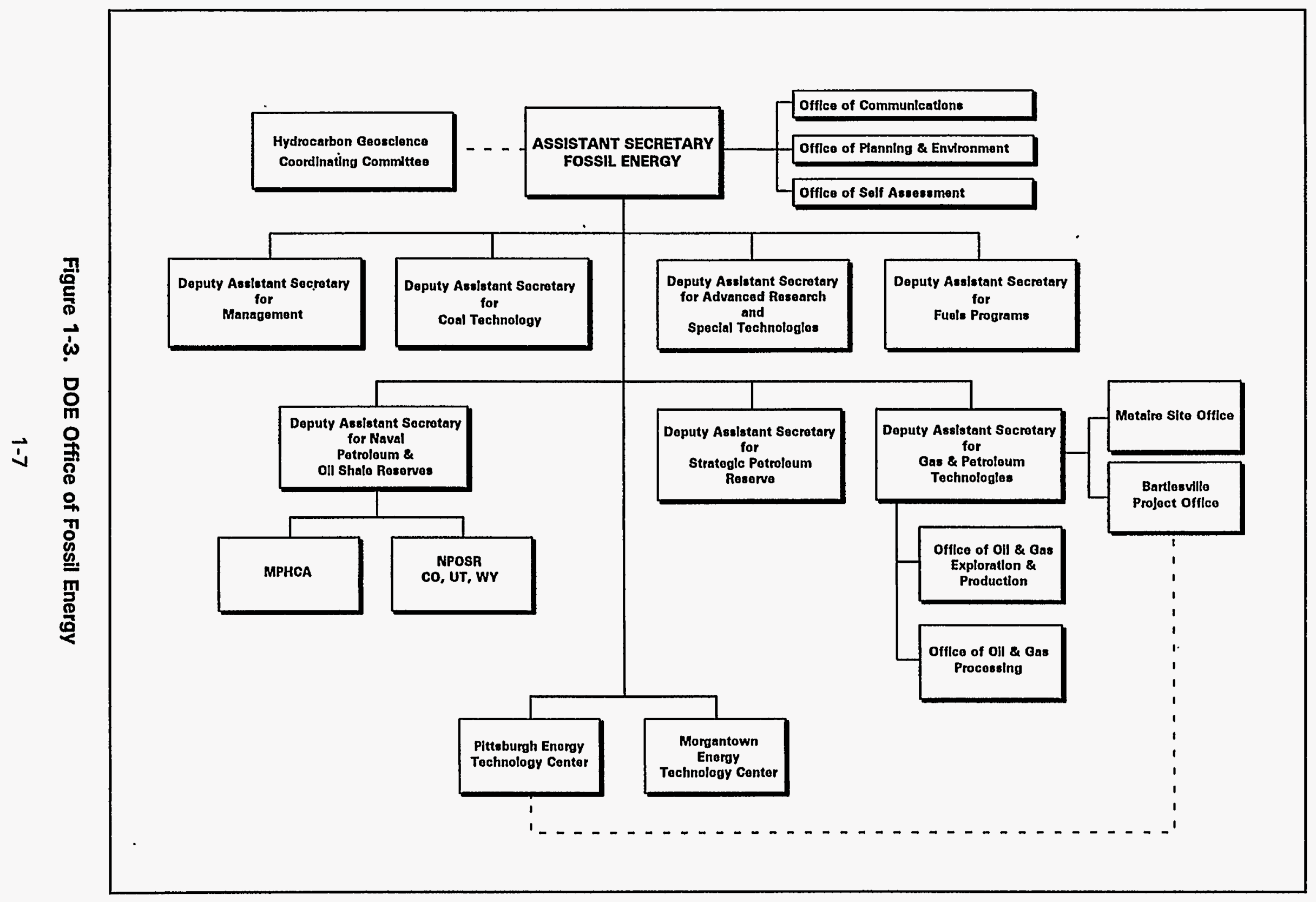


BPO has four line management offices and a non-line Quality Assurance organization under the Office of the Director (see Figure 1-4). BPO environmental responsibilities include implementing environmental policy at $\mathrm{BPO}$, integrating environmental policy and compliance into annual plans, performing management and functional appraisals of BDM-OK, initiating procurement requests for environmental compliance, and tracking and reporting BDM-OK environmental compliance activities. The environmental project manager within BPO is charged with conducting oversight of facility environmental operations and currently resides within the line management organization designated as the Office of Advanced Extraction and Process Technology.

BDM-OK is a subsidiary of BDM Federal, which in turn is a subsidiary of BDM International. BDM-OK contains four line management departments and two non-line organizations, in which ES\&H and Quality Assurance staff reside. Figure 1-5 shows the organizational structure of BDM-OK, and Figure 1-6 shows the structure of ES\&H.

PETC provides support to BPO through environmental policy implementation of contracts, review of environmental compliance reports, and legal adequacy review of NEPA documents. PETC obligates appropriated funding for NIPER environmental activities pursuant to BPO procurement requests and has located one administrative contract officer at BPO.

FE-30 is charged with implementing the Oil Research Program Implementation Plan. It also provides assistance with the development, integration, and review of environmental policies, and it allocates programmatic resources for environmental activities in BPO projects and reviews and recommends corrective actions for BPO/NIPER.

FE- 6 is charged with ensuring environmental compliance and works to develop a philosophy of positive environmental culture in Federal and contractor operations. FE-6 offers support through environmental policy review, interpretation, and dissemination; self-assessment policy development and guidance; review of resource allocations for environmental activities; review of policy integration; and coordination of Headquarters reviews of NEPA documents. 


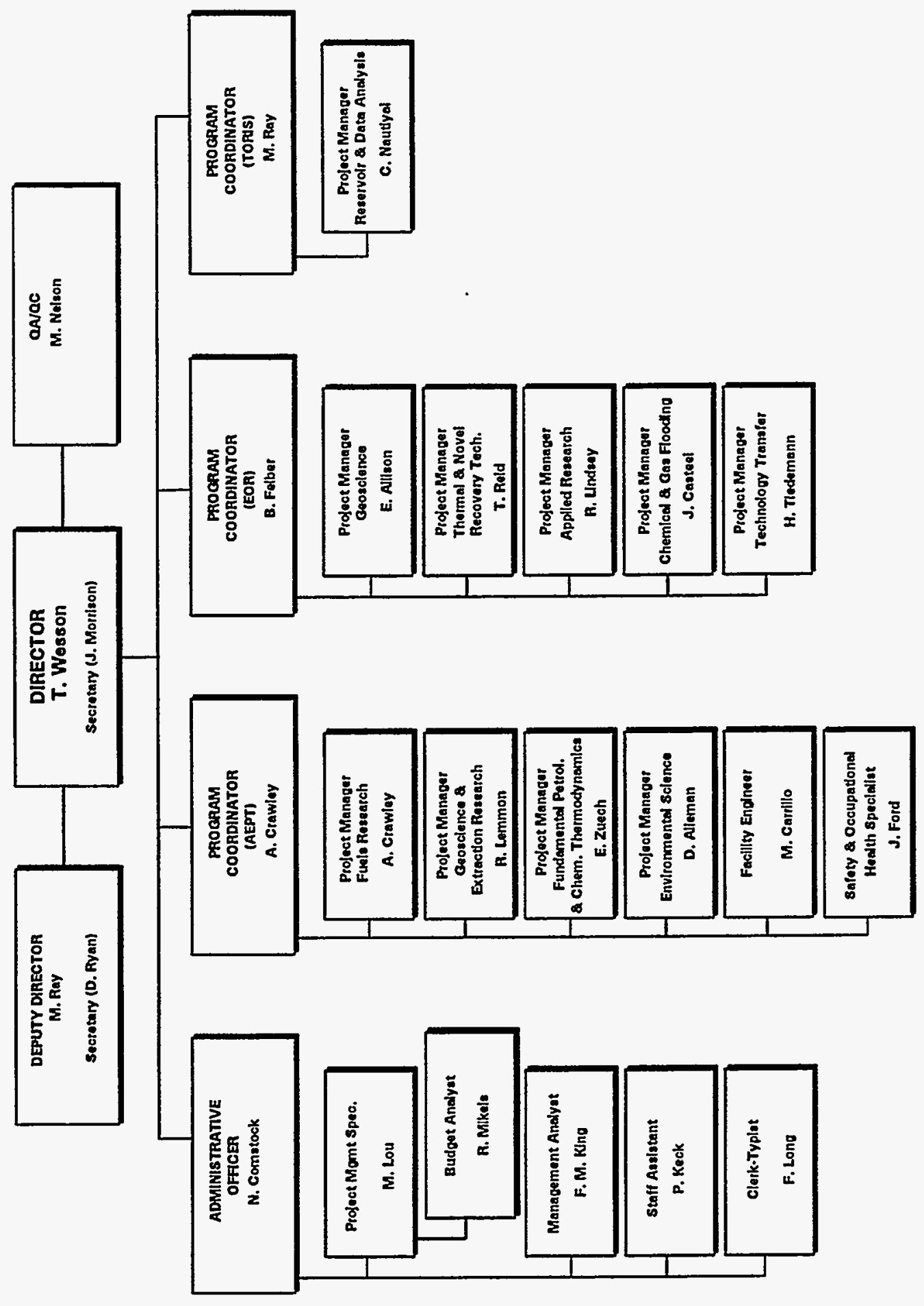

Figure 1-4. Bartlesville Project Office 


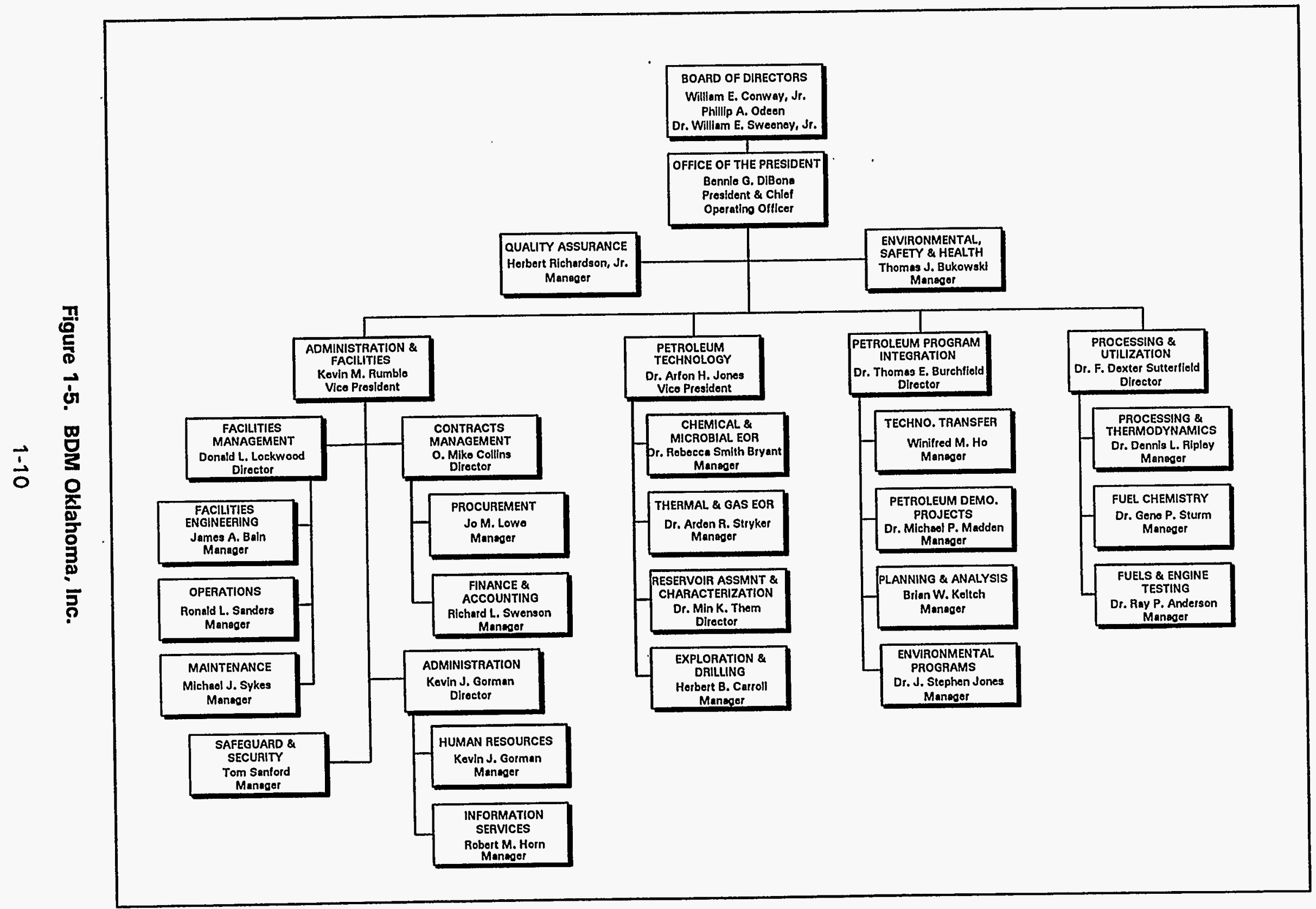




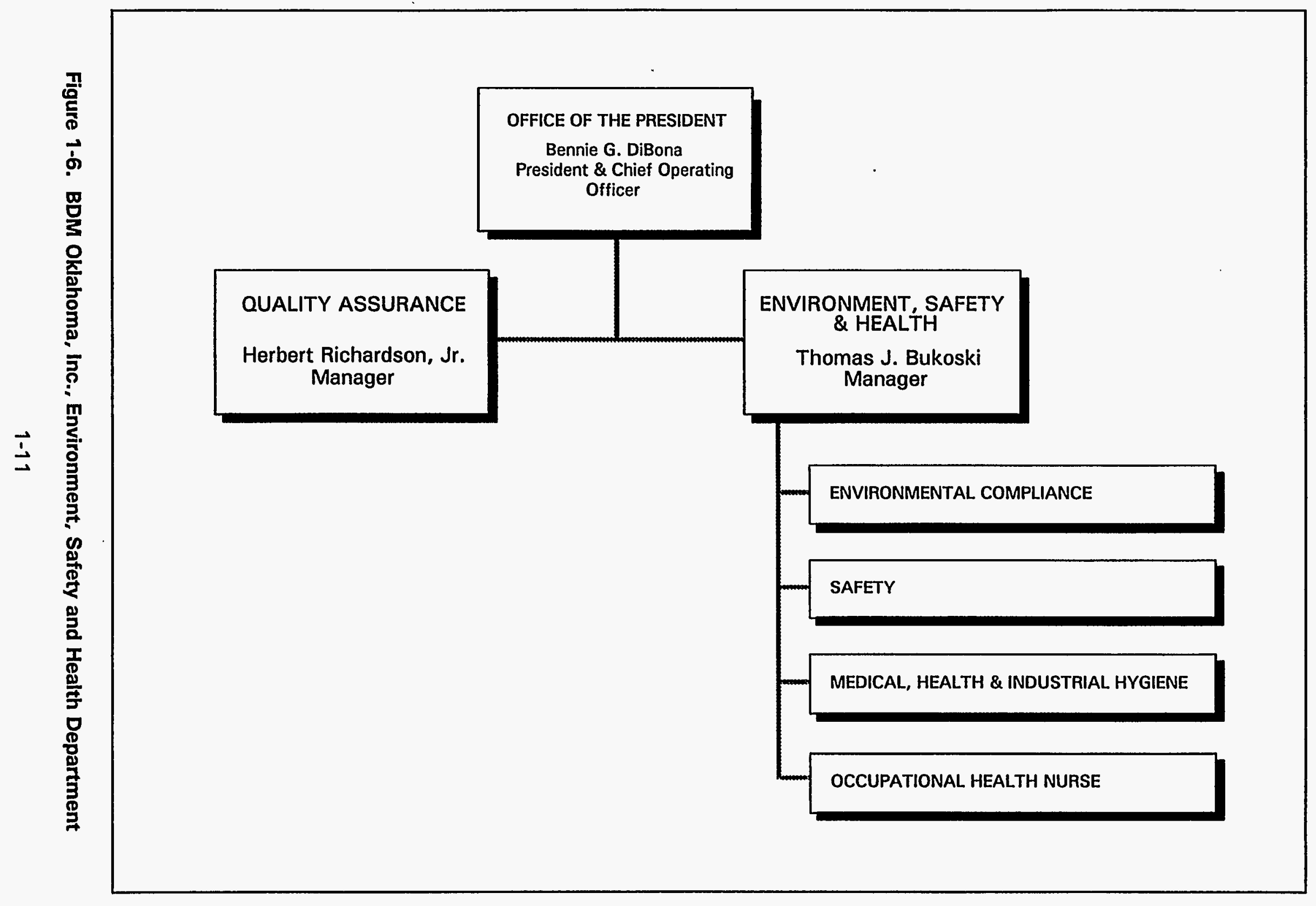


This page intentionally blank 


\section{SECTION 2.0}

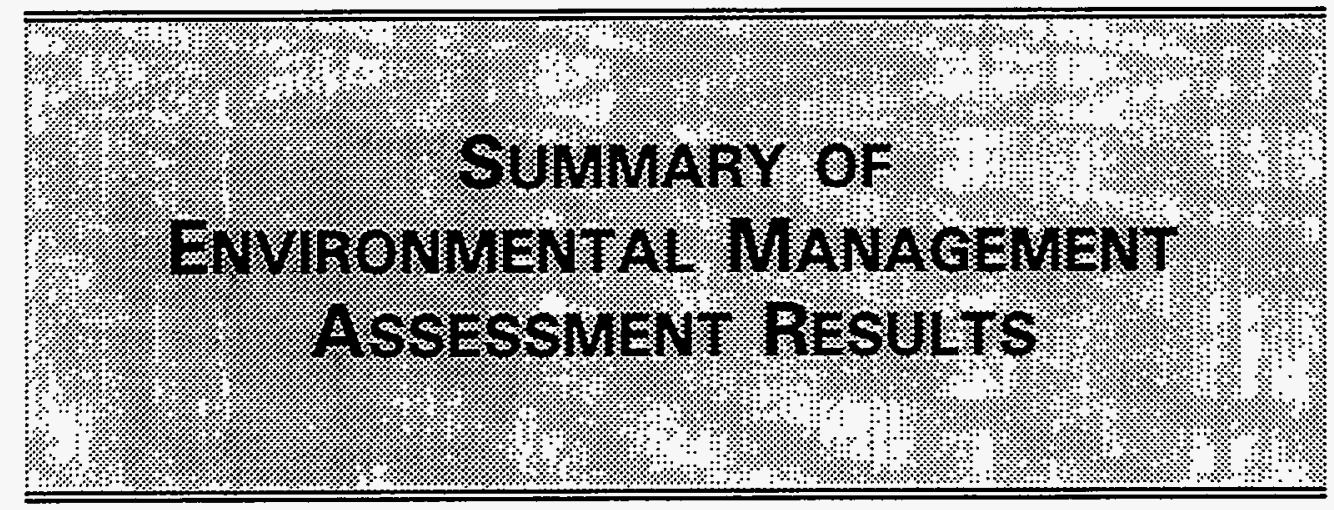


Page intentionally blank 
The following summarizes the results and conclusions the assessment team developed for the environmental management assessment of the National Institute for Petroleum and Energy Research (NIPER) conducted August 15-26, 1994.

Environmental protection programs and management systems at NIPER are in the early stages of development and implementation because of a recent change in NIPER's management structure. Before January 1, 1994, NIPER was operated under a cooperative agreement between DOE and an outside contractor. This agreement did not contractually obligate the contractor to comply with DOE Orders. On January 1, 1994, BDM Oklahoma (BDM-OK) assumed operation of NIPER under a management and operating (M\&O) contract that requires compliance with all applicable DOE Orders. Since that time, BDM-OK has been working under aggressive schedules to develop and implement the environmental programs required by DOE Orders.

Although significant work remains to be done, the assessment team believes that BDM-OK is making appropriate progress in the development and implementation of environmental programs and management systems. Therefore, findings were not developed against programs that are planned and proceeding according to schedule.

Overall, the assessment revealed that both BPO and BDM-OK environmental staffs are dedicated and consistently exhibit a high level of environmental commitment. Further, internal communication between BPO and BDM-OK organizations have enhanced the development of an open and effective working relationship.

During the assessment four findings were identified in the areas of formality of environmental programs; staff resources, training and development; program evaluation, reporting and corrective action; and environmental planning and risk management. Summaries of these findings are found in Section 2.1 of this report.

The assessment team identified the following strength in the environmental programs at NIPER:

- BDM-OK Environmental Personnel Dedication. BDM-OK environmental management and staff have demonstrated an outstanding dedication to the accomplishment of onsite environmental protection. The high level of commitment to achieving environmental excellence is a key component to the development of successful environmental operations at NIPER. 


\section{1}

The following paragraphs briefly describe the findings in the management systems and technical discipline discussed in the assessment. Full details for each discipline are found in the overviews and findings in Section 3 of this report.

Organizational Structure (OS). No findings were identified in this portion of the assessment. Refer to Section 3.1.1 for the overview of this discipline.

Environmental Commitment (EC). No findings were identified in this portion of the assessment. Refer to Section 3.2.1 for the overview of this discipline.

Environmental Protection Programs (EP). No findings were identified in this portion of the assessment. Refer to Section 3.3.1 for the overview of this discipline.

Formality of Environmental Programs (FP). One finding was identified in this portion of the assessment, relating to a lack of formality and documentation of environmental programs at NIPER. Regulatory tracking systems, environmental procedures, facility inspections, and reporting are not formally or consistently documented. Since BDM-OK began operations of NIPER, this lack of formality has not resulted in any serious consequences for the site, but the lack of formality makes it difficult for DOE to ensure that progress toward achieving environmental compliance is proceeding appropriately. Refer to Section 3.4.1 for the overview of this discipline.

Internal and External Communication (IC). No findings were identified in this portion of the assessment. Refer to Section 3.5.1 for the overview of this discipline.

Staff Resources, Training, and Development (SR). One finding was identified in this portion of the assessment, relating to the development and implementation of BPO staff training and development programs. Currently, the joint efforts of PETC and BPO have not adequately provided input into environmental training and individual development plans for BPO personnel with environmental responsibilities. In addition, BPO is not conducting environmental awareness training for its existing staff and new employees. Refer to Section 3.6.1 for the overview of this discipline.

Program Evaluation, Reporting, and Corrective Action (PE). One finding was identified in this portion of the assessment, relating to self-assessment and appraisal programs.

Although a number of program evaluation activities have taken place at NIPER, deficiencies were identified in the programs of FE, BPO, and BDM-OK. Refer to Section 3.7.1 for the overview of this discipline.

Environmental Planning and Risk Management (RM). One finding was identified in this portion of the assessment relating to BPO's oversight of environmental project expenditures. Because the present system does not allow BPO to track expenditures by project, BPO's ability to make accurate budgeting forecasts is impeded. Refer to Section 3.8.1 for the overview of this discipline.

Quality Assurance (OA). No findings were identified in this portion of the assessment. Refer to Section 3.9.1 for the overview of this discipline. 
A key finding is a finding, or group of findings, related to the same issue, which, in the judgement of the assessment team, is essential to understanding the nature and scope of environmental management deficiencies of the facility being assessed. Based on the nature and number of findings the team identified, there were no key findings in this assessment. The team did find, however, that there is one significant observation regarding weakness in BPO environmental oversight. BPO currently conducts most of its environmental oversight activities informally. There is a lack of formality associated with the planning and implementation of BPO environmental management systems that does not permit proper analysis of pertinent environmental information. Formality is an essential component of effective environmental management systems that will promote sustained excellence and continuous improvement in environmental operations. This situation has not, however, currently resulted in the manifestation of new environmental compliance issues because of BPO's and BDM-OK's effective relationship, which is providing momentum toward the accomplishment of environmental goals. 
This page intentionally blank 


\section{SECTION $\mathbf{3 . 0}$}

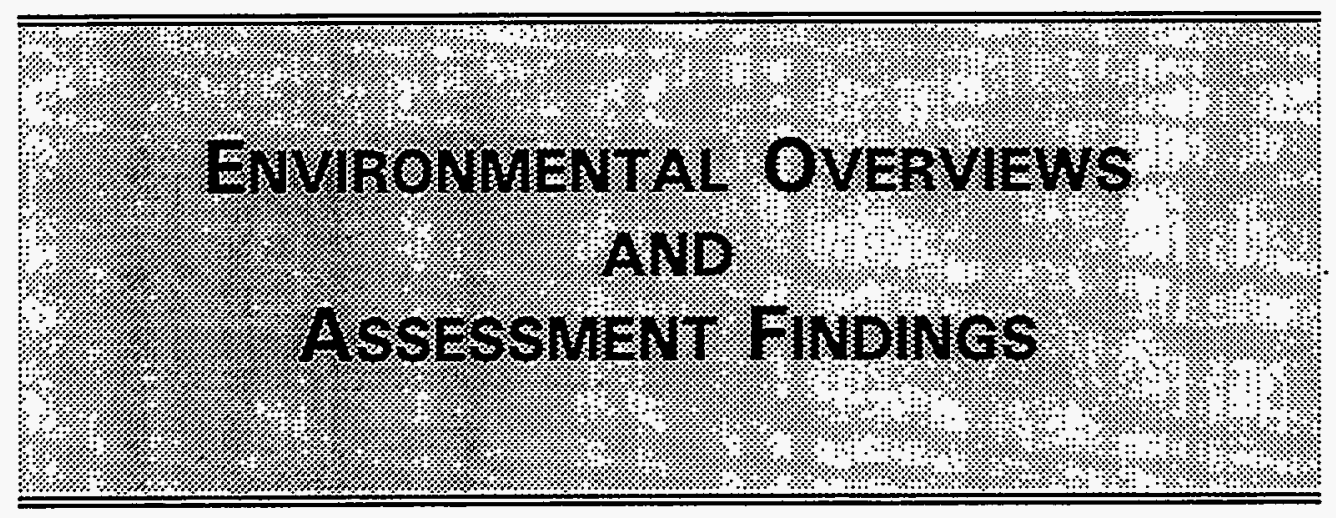


Page intentionally blank

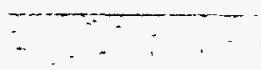


The assessment findings are presented in the following pages and are not necessarily in order of importance. They are grouped by relevant management system areas as listed in the Protocols for Conducting Environmental Management Assessments (DOE/EH-0326, June 1993) and are preceded by an overview. The overview describes (1) the approach the management systems specialist took in conducting that portion of the assessment, (2) the NIPER programs and activities related to the relevant management system areas, (3) a characterization of the strengths and weaknesses of NIPER activities, and (4) a brief summary of the findings. Each finding is organized into three sections-the performance objective, the finding statement, and a discussion. The performance objectives specify the particular practices or standards against which the finding is being evaluated, and the discussion details the facts and observations supporting the finding.

Within each finding, references to other findings, interviews, and documents are presented parenthetically. An example of a referenced finding is "(see Finding OS-1)," in which "OS" stands for "Organizational Structure," and " $q$ " is the finding number. Other abbreviations used to identify findings are as follows:

$\begin{array}{ll}\text { OS } & \text { Organizational Structure } \\ \text { EC } & \text { Environmental Commitment } \\ \text { EP } & \text { Environmental Protection Programs } \\ \text { FP } & \text { Formality of Environmental Programs } \\ \text { IC } & \text { Internal and External Communication } \\ \text { SR } & \text { Staff Resources, Training, and Development } \\ \text { PE } & \text { Program Evaluation, Reporting, and Corrective Action } \\ \text { RM } & \text { Environmental Planning and Risk Management } \\ \text { OA } & \text { Quality Assurance }\end{array}$

Several of the assessment team specialists covered more than one of the management system areas listed above. As such, interviews and document reviews were quite often completed with multiple areas of responsibility in mind. To reduce unnecessary duplication when referencing interviews and documents, they are identified as follows. An example of a referenced interview is " $(1-A-1)$ " where "l" signifies an interview, "A" represents an individual assessment team member, and " 1 " is the specifically assigned sequential interview number. An example of a referenced document is " $(D-A-1)^{n}$ where " $D$ " signifies a document, " $A$ " represents an individual assessment team member, and " 1 " is the specifically assigned sequential document number. The lists of documents reviewed and interviews conducted are presented in Appendices $D$ and $E$ respectively. 


\subsubsection{Overview}

The purpose of the organizational structure portion of the NIPER environmental management assessment was to assess characteristics of the organization such as the definition of functional responsibilities and authorities, the reporting levels and relationships of environmental staff, the layers of management and span of control, and the support systems such as management reporting requirements and performance measurement and incentives. The assessment included a review of the relationship, oversight, support, and line management activities among FE, PETC, BPO, and BDM-OK. Specific regulations, requirements, and guidelines used in the assessment are shown in Appendix $F$.

The general approach to this portion of the assessment was to review DOE Orders and NIPER documents before coming onsite. Onsite activities focused on interviewing NIPER employees and reviewing additional documents. Within BDM-OK, interviews were held with personnel in the Office of the President, the ES\&H Department, and project research at the facility. Within BPO, interviews were held with personnel from the Office of the Director, the Office of Advanced Extraction and Process Technology, the Office of Administration, and the Office of Enhanced Oil Recovery. An interview was held with the FE Office of Self Assessment and the PETC Administrative Contracting Officer for the BDM-OK contract (I-A-15). Documents reviewed during onsite activity included organizational charts; the ES\&H Management Plan Activity Data Sheet; memorandums from BDM-OK, BPO, and PETC; position descriptions; and résumés.

Three discrete organizational layers were identified and evaluated at NIPER. These include the organizational relationships between the following:

- BDM-OK ES\&H Department and BDM-OK environmental coordinators within line organizations;

- $\quad B P O$ and BDM-OK; and

- FE, PETC and BPO;

Each of these relationships was assessed to determine whether the lines of authority and roles and responsibilities between parties were consistent with site environmental requirements.

\section{BDM-OK ES\&H Department and Environmental Coordinators}

The BDM-OK ES\&H Department appears to be well placed within the organization and demonstrates full competence and support in efforts to manage environmental protection programs for BDM-OK. Planned activities designed to enhance the effectiveness of the ES\&H Department involve the introduction of a network of environmental coordinators (D-A-11; I-A-2). This network will consist of line personnel charged with integrating "environmental compliance and management requirements into their respective departments." The environmental coordinators will "act as a liaison with ES\&H" to assist line management in fulfilling its environmental responsibilities in an effort to leverage the ES\&H Department responsibilities with line personnel. BDM-OK management plans to 
make the environmental coordinators accountable for its environmental responsibilities after proper training has been completed. Interviews with employees assigned to this position were comfortable with their new responsibilities and understood the purpose of their task (I-A-6 and I-A-7). Further, they were confident that they would receive the necessary training and support from the ES\&H Department to carry out their programmatic responsibilities. ES\&H has issued a memo to the environmental coordinators explaining the procedures to be followed, training to be acquired, and responsibilities to be assumed (D-A-11; I-A-11).

\section{BPO and BDM-OK}

The relationship between BPO and BDM-OK consists of an oversight responsibility on the part of BPO (I-A-4). It is BPO's responsibility to ensure BDM-OK's compliance with all Federal, state, and local environmental regulations and with DOE Orders. BDM-OK's ES\&H Department is responsible for implementing programs that will ensure this compliance, such as environmental sampling and training. Environmental roles and responsibilities between BPO and BDM-OK are clearly understood (1-A-2, I-A-3, and I-A-4). Although there is a lack of formality on the part of BPO surrounding these oversight activities, the environmental oversight responsibilities are being carried out (see Finding FP-1).

Within BPO the position of environmental manager is currently placed in a line organization, under the program coordinator for the Office of Advanced Extraction and Process Technology (D-A-20). The environmental manager has the authority, respect, and independence to implement environmental programs effectively and to make decisions related to environmental protection. The present organizational structure, however, does not clearly show this independence from line authority (I-A-3 and I-A-4). Other independent site functions such as quality assurance/quality control are organizationally independent of line authority and report directly to the Office of the Director. Interviews with the director of BPO indicate that an upcoming organizational restructuring will plan for the environmental manager position to be outside the line organization (I-A-8).

\section{FE, PETC \& BPO}

BPO is one of three offices with research responsibilities in FE, the other two being the Morgantown Energy Technology Center (METC) and the Pittsburgh Energy Technology Center (PETC) (I-A-20). The three facilities have coequal responsibilities with respect to their fossil energy research: BPO is responsible for conducting petroleum-related research, PETC for coal research, and METC for coal and natural gas research. Although they share similar research roles, BPO is distinct from the others with respect to reporting and oversight authority. Programmatically, the Deputy Assistant Secretary for Gas \& Petroleum Technologies (FE-30) has oversight authority over BPO, but the Assistant Secretary of Fossil Energy (FE-1) has direct oversight of METC and PETC (D-A-10 and $D-A-20 ; 1-A-12)$. FE-30's role is to oversee research funds for BPO and in specific cases act as an advocate for BPO to FE-1 for environmental activities, for example, funding for Tiger Team corrective actions (I-A-8 and I-A-9).

Through round-table discussions with all three offices, the FE Office of Self Assessment (FE-6) facilitates the allocation of Environmental Restoration funds originating at FE-1 (D-A-10; I-A-12). This division of FE-30 and FE- 6 oversight of BPO appears to be successful on a practical level, but written documentation outlining roles and 
responsibilities for FE-6 and BPO is unclear (1-A-9 and $1-A-12)$. This is presented as supporting information in Finding FP-1 (D-A-10). The April 10, 1992, memo outlining FE roles and responsibilities for NIPER states that FE- 6 will "review allocations of resources for ES\&H activities by FE-30, PETC, and BPO" (D-A-5). The lack of clarity lies in the definition of ES\&H activities and in FE-6's level of "review." As stated above, FE-6 is more actively involved in the allocation of Environmental Restoration funds than the word "review" would imply. Although BPO personnel are comfortable with their interaction with FE-6, the present documentation does not clearly convey the actual relationship.

A second organizational distinction for BPO is that PETC and METC have total authority over their respective contractors, but BPO has programmatic authority over BDM-OK only; contractual authority lies with PETC (I-A-8, I-A-13, and I-A-16). Therefore, a PETC administrative contracting officer resides at BPO to facilitate BPO contracting requirements (D-A-21; I-A-14 and I-A-15). Interviews with site personnel and documentation referencing procurement dates for several environmental contracts indicated instances in which requests did not appear to be acted upon by PETC in a timely manner (D-A-25; 1-A-14, 1-A17, and $(-A-19)$. The assessment team does not believe, however, that these incidents indicate an overall management system problem affecting NIPER environmental operations.

Overall, the assessment team believes that NIPER's organizational structure is well understood, if not fully documented. Therefore, no findings were identified in the organizational structure portion of the assessment. 


\subsubsection{Overview}

The purpose of the environmental commitment portion of the NIPER environmental management assessment was to evaluate the level of commitment to environmental protection exhibited by BDM-OK and BPO. Environmental commitment in this context is defined as follows:

- the demonstration of senior management's commitment to environmental protection through formal statements;

- managerial decisions, actions, attitudes, and interests;

- the establishment of organizational policy that places environmental protection as a top priority - on an equal level with research activities; and

- the awareness of and line responsibility for environmental protection at all levels and across all functions within the organizations.

The general approach to this portion of the assessment was to review site documents BDM-OK and BPO provided before the onsite portion of the assessment. Onsite activities focused on interviewing NIPER employees and reviewing additional documents. Within BDM-OK, interviews were held with personnel from the Office of the President, personnel from the ES\&H Department, and personnel involved in project research at the facility. Within BPO, interviews were held with personnel from the Office of the Director and the Office of Advanced Extraction and Process Technology, and with other cognizant personnel. Also interviewed was the DOE Office of Fossil Energy (FE) Director of the Office of Self Assessment. Documents reviewed during onsite activities included BDM-OK memorandums addressing environmental commitment and policy for the site, position descriptions, and a memo outlining FE and BPO responsibilities.

BDM-OK began demonstrating its commitment to the environment before commencement of operations in January 1994. In November 1993 BDM-OK hired an outside consultant to perform an ES\&H multimedia compliance audit of the facility. As a first action BDM-OK management shut down the facility on the first day of official operation by the $M \& O$ contractor. The purpose of the shutdown was to enable the facility to begin addressing highest priority issues among the approximately 900 ES\&H findings brought to light by the audit; approximately 170 of these were environmental findings. This shutdown was announced to BDM-OK personnel at an "all-hands" meeting that the president of BDM-OK called on the first day of operation under the new M\&O contract. There have been two more "all-hands" meetings since.

Senior BDM-OK management has continued to demonstrate its commitment to the environment. Although safety and health audit findings were the primary concern for the shutdown, environmental protection measures have been given equal weight in the site's subsequent efforts to improve ES\&H-related activities. Senior management has made a strong effort to convey its commitment to the environment to site personnel through memos, "all-hands" meetings, and the ES\&H Department. All BDM-OK employees have begun environmental training, and several more courses are scheduled. The ES\&H 
Department has made a successful effort to be available to line personnel to answer any environmental concerns that may arise in the field. In July 1994 BDM-OK issued two memorandums to all employees, explaining BDM-OK's policy on and commitment to environmental protection. In accordance with DOE Order 5480.19 Conduct of Operations for DOE Facilities, BDM-OK is in the process of establishing an ES\&H Committee to "enhance management and employee commitment, and encourage employee involvement with the mission of protecting the safety and health of facility personnel, the public, and protecting the environment."

Interviews with BDM-OK employees confirmed senior management's efforts to impress upon operating staff that environmental compliance takes priority in all operations. Employees felt that they clearly understood senior management's position regarding the environment and expressed a sense of ownership of their environmental protection duties as a result of senior management's message. Employees expressed their comfort with approaching the site's environmental staff for any environment-related issue, whether it be a spill/release or a design flaw with possible negative environmental effects. Employees also felt that they have been granted "stop work" authority by senior management in the event of any actual or potential environmental incident. Further, site employees expressed a level of confidence in the environmental training program currently under way. Lastly, the ES\&H Department has initiated an ES\&H hotline for employees to voice any concerns they may have for environmental issues.

Although BDM-OK senior management has initiated several programs demonstrating its commitment to the environment, there is no mechanism for reporting its activities and progress formally. For example, although regular meetings are held involving the president of BDM-OK, the manager of the ES\&H Department, the director of BPO, and the BPO environmental manager, there are no documented results of these discussions (see Finding FP-1).

The BPO/BDM-OK cooperative commitment is resulting in the development of management systems designed to ensure sound environmental protection at NIPER. On June 8, 1994, BPO issued a memorandum to all BPO and BDM-OK employees regarding BPO's policy and practice of environmental protection (D-A-26).

In total, the site has effectively demonstrated commitment to environmental protection. Given the multitude of environmental findings uncovered by the independent consultant, the site is to be commended for addressing these environmental concerns with a sense of urgency and with apparent success. Therefore, no findings were identified in the environmental commitment portion of the assessment. 


\subsubsection{Overview}

The purpose of the environmental protection programs portion of the NIPER environmental management assessment was to evaluate the extent to which environmental protection programs have been developed as required in DOE Orders and best management practices. Appendix $F$ includes the regulations, requirements, and guidelines used in conducting this assessment.

Before 1994 NIPER was operated under a cooperative agreement (CA) between DOE and an outside contractor. This arrangement did not contractually obligate the contractor to comply with DOE Orders. As of January 1, 1994, NIPER began operations under a management and operating (M\&O) contract with BDM-OK as the prime contractor. This new arrangement requires BDM-OK to comply with all applicable DOE Orders in addition to Federal, state, and local environmental regulations. The result is a unique situation in that many environmental programs are not presently in place but are being developed and implemented under very aggressive schedules. The lack of many environmental programs was identified as a series of compliance issues in the Tiger Team Assessment (D-B-1) and in a separate assessment conducted by Geraghty and Miller beginning December 1993 and ending May 1994 (D-B-5). Additionally, BDM-OK conducted an internal comprehensive environmental, health, and safety assessment of the facility beginning in January 1994 and ending in May 1994 (D-B-10). The three assessments were used to establish a baseline of compliance with Federal, state, and local regulations, and good management practices. Identifying identical compliance issues in this assessment would not assist the site in achieving compliance. Therefore, this assessment evaluated the management of the programs being developed and the progress achieved on these programs.

The general approach to this portion of the assessment was to review DOE Orders, environmental regulatory requirements, and site documentation provided before the onsite portion of the assessment. Environmental personnel from BDM-OK and BPO were interviewed, as was management responsible for environmental activities within both organizations. Some BDM-OK program managers were also interviewed.

A programmatic investigation of various environmental issues pertaining to the site was conducted in conjunction with the management assessment of the environmental protection programs. These issues included air, surface water, groundwater, management and control of toxic and chemical materials, and management of hazardous and mixed waste.

Environmental protection programs and plans that are complete, that are required by DOE Order or regulatory statute, and that were evaluated include the following:

- Toxic Chemical and Hazardous Materials Management and Waste Disposal Plan;

- Comprehensive ES\&H Program Implementation Plan;

- Waste Minimization and Pollution Prevention Awareness Plan; 
Draft Environmental Monitoring Plan for Management and Operating Contract for the Department of Energy's National Oil and Related Programs;

- BDM-OK Quality Assurance Program Plan;

- BDM-OK Quality Assurance Implementation Plan;

- BDM-OK Quality Assurance Assessment Plan;

- Draft Groundwater Protection Management Plan; and

- BPO Quality Assurance Program.

Specific discussions regarding programs reviewed as part of the environmental protection programs portion of the assessment follow.

\section{Air Program}

Various sources of air emissions exist at NIPER. These include laboratories and other research facilities, storage tanks, boilers, and internal-combustion engines used for research (D-B-1). The pollutants emitted from these sources include $\mathrm{NOx}, \mathrm{SO}_{2}, \mathrm{CO}, \mathrm{VOCs}$, and particulates. Air streams from facilities and equipment are uncontrolled and vent directly to outdoor air (D-B-1). No radiological emission sources exist at NIPER (I-D-14), and no research plans currently exist that would produce radiological emissions.

NIPER is not currently conducting air emission monitoring (1-B-1). It has received informal notice from the Oklahoma Department of Environmental Quality (DEQ) that a permit is not required, but no documentation from DEQ verifying this notice is available (I-B-1). BDM-OK has recognized the need to ensure compliance as required by DOE Orders. Plans are currently in place to develop a comprehensive air program at NIPER (D-B-13). These activities will include developing an inventory of all air emission sources, evaluating background air concentrations, monitoring emissions, dispersion modeling of onsite and offsite air concentrations resulting from emissions at the facility, and evaluating the need for air permits.

\section{Wastewater/Surface Water/Drinking Water Programs}

NIPER purchases its drinking water from, and discharges its wastewater to, the City of Bartlesville (I-B-1). Wastewater is generated and released from a variety of sources at NIPER. These include laboratories, domestic sewage, cooling units, boiler blowdown discharges, and stormwater runoff. Pollutants potentially contained in wastewater include suspended solids, BOD, cadmium, chromium, copper, lead, nickel, zinc, silver, cyanide, oil and grease, phenols, acids, and bases (D-B-1). No radiological materials that could enter the wastewater stream are present on the NIPER site (I-D-14). 
Stormwater runoff from the NIPER site discharges to offsite surface drainage ditches at two or three points on the northern edge of the property and at two points in block $A$ of the site.

NIPER currently does not have an industrial wastewater discharge permit because the City of Bartlesville does not consider the facility a significant industrial user (D-B-1). No monitoring activities of wastewater discharge are required. Plans are currently in place to develop a comprehensive wastewater monitoring and surveillance program (D-B-4). The objectives of this program include verifying compliance with the City of Bartlesville pretreatment ordinance and DOE Orders and detecting any unplanned releases. A formal program is also being established to install, inspect, and maintain backflow-prevention devices and cross-connection controls as required by DOE Orders and the City of Bartlesville (D-B-4).

\section{Spill Prevention Planning}

BDM-OK is currently in the process of updating the Spill Prevention Control and Countermeasure Plan (SPCC). A number of aboveground and underground storage tanks are present onsite from which spills could occur (I-B-1, I-B-3, and I-B-5). A plan to reevaluate usage and upgrade the aboveground tanks, as necessary, by improving secondary containment and installing high-level alarms is scheduled for completion by the end of calendar year 1994 (I-B-1 and I-B-5).

\section{Groundwater}

The groundwater protection program at NIPER is currently under development, so little information is available regarding groundwater quality (I-B-1). Many potential sources of groundwater contamination exist as a result of past activities at the site (D-B-5). Potential sources of groundwater contamination include aboveground storage tanks (ASTs) and underground storage tanks (USTs). One underground tank is actually an old railroad tank car that was buried and used for liquid storage. This tank was filled with bentonite and abandoned in place. Several potential inactive waste sites exist, including two to eight abandoned oil wells, an old experimental refinery, and numerous hazardous material and petroleum storage and use areas (D-B-1 and D-B-5). Contaminated fill material may have also been used at the site before construction of many of the buildings. The presence of numerous oil production wells in the Bartlesville area, together with the potential for high metals concentrations resulting from the nearby zinc smelter will require special consideration during development and implementation of a groundwater monitoring plan.

$\dot{A}$ groundwater program required to meet DOE Orders has not yet been established at NIPER. Development of a groundwater protection management plan and a groundwater monitoring plan, however, has been scheduled for completion by the end of fiscal year 1994 (D-B-4). Initial groundwater characterization has been scheduled for completion by the end of the second quarter of fiscal year 1995 (D-B-4).

Activities Conducted under the Comprehensive Environmental Response, Compensation, and Liability Act (CERCLA)

The only activity conducted at NIPER to date was the development of a preliminary assessment (PA) under CERCLA (D-B-17). The PA essentially evaluated all potential 
sources of contamination at NIPER and their locations. Actual treatment of contaminated environmental media has not been conducted.

\section{Toxic and Chemical Materials Program}

NIPER uses numerous toxic and chemical materials (D-B-1). The majority of materials include gasoline, diesel fuel, and crude oils. Other chemicals include chlorinated and nonchlorinated solvents, organic and inorganic salts, acids, and bases. Minor amounts of polychlorinated biphenyls (PCBs) were identified during the Tiger Team assessment (D-B-1). Asbestos is also present onsite. Pesticides and herbicides are not stored onsite and are applied by commercial contractors only. Biocides applied in cooling towers are used by NIPER personnel (D-B-1). Storage of chemicals is primarily in buildings 8 and 16 , but many chemicals are stored in individual laboratories. Minor amounts of waste oil containing trace levels of Cobalt-56 and Manganese- 54 below background levels are present onsite (I-D-14).

A system for procurement, use, tracking, and storage of toxic and chemical materials is currently under development (I-B-1 and I-B-5). Procurement of new chemicals at NIPER is initiated by NIPER employees through the submittal of a purchase requisition. No mandatory review by environmental personnel is currently required before the purchase and release of the requisitioned toxic and chemical materials (I-D-9). A review is conducted only if the research project manager requests such service from the environmental compliance officers. NIPER is currently planning to implement a mandatory and formal review process for chemical purchases.

A bar coding system was established in late 1993 to track all chemicals. The system requires that a coded sticker be attached to all chemicals and logged into a central system. No centrally networked computer system has been established at the site, however, so all information must be hand written onto the appropriate forms (I-D-9). Another problem with the system is that no central storage area has been established where chemicals can be inventoried and distributed.

\section{Waste Management Program}

Hazardous Waste Management is controlled through the environmental compliance officer for BDM-OK. Various sources of waste include waste oil and solvents, gasoline, laboratory reagents, acids, bases, degreasers, waste paint, and miscellaneous hazardous wastes (D-B-1). Hazardous waste is collected at various satellite accumulation areas throughout the site. Solvent waste is transferred to the temporary accumulation area located at building $5 \mathrm{~A}$ prior to transport to a commercial treatment storage and disposal facility (D-B-1). BDM-OK has recently established a contract to dispose of hazardous waste. Nonhazardous waste is collected and transferred to the Bartlesville Public Landfill. When necessary, asbestos waste is also shipped to this landfill after proper packaging (D-B-1). The landfill is certified to receive asbestos waste (D-B-1). A draft Waste Minimization and Pollution Prevention Awareness Plan has been developed and was submitted to BPO in June 1994 (I-B-5). 


\section{Environmental Radiation Program}

Current activities at NIPER that use radiation or low levels of radioactive materials include radioactive piston rings that contain low levels of Manganese-54, Chromium-51, and Cobalt-56; X-ray machines; Computer Aided Tomography (CAT) scanning equipment; and laboratory instruments that contain Nickel-63 (D-B-1; I-B-5 and I-D-14). A review of sources of environmental radiation determined that waste oil containing trace levels of Cobalt -56 and Manganese- 54 below background levels is present onsite. Disposal of this material is scheduled soon (I-D-14). Various engine parts containing Cobalt-56 piston rings also exist onsite in a storage area for radioactive material. NIPER facilities, including the $X$-ray facilities (fixed, CAT, and diffraction), are inspected by a contracted certified health physicist every 12 months. The only other radionuclides used onsite are Nickel-63 sealed sources that are an integral part of the site's gas chromatographs (I-D-14). These items are exempt from NRC licensing because BDM-OK is a primary DOE contractor, and the items are covered under a general license issued to the manufacturers.

\section{Preventive Maintenance Program}

No pollution control equipment, such as wastewater treatment systems and air pollution control devices, is currently present onsite (1-B-1). Therefore preventive maintenance in the strictest sense is not required. Preventive maintenance consists primarily of inspections to ensure that laboratory vent hoods are working properly, chemicals are stored properly, and, in general, any environmental issues that may be of concern are identified. These inspections are not formally documented (see finding FP-1).

\section{Quality Assurance Program}

NIPER is currently in the process of developing and implementing its Quality Assurance Program. The Quality Assurance Program Plan, Implementation Plan, and Assessment Plan have been generated, and implementing procedures are being developed. The current implementation schedule will provide timely program implementation, and implementation actions are currently on schedule. A detailed description of the NIPER QA Program can be found in the Quality Assurance section of this report.

Because of the historical context of site operations and the relatively short period of time since beginning operation under an M\&O Contract, many of the environmental protection programs mandated by DOE Orders have not been developed or implemented. Although the assessment team believes this is an important issue, a formal finding was not warranted because of the above-mentioned scenario and the team's high level of comfort with the site's environmental planning process. Notification and qualification of the team's conclusion, however, was considered necessary for the assessment.

Several activities have been undertaken that have raised the team's confidence that the facility is moving in the right direction related to environmental compliance and planning. Some of these activities include the following:

- BDM-OK's completion of a risk assessment of audit findings and its prioritization of the corrective actions according to the risk involved; 
- BDM-OK's establishment of management systems concurrently with correcting individual deficiencies in order to institute the necessary controls for improved and continued compliance; and

- BDM-OK's preparation of documents that clearly outline the programs that will be developed and the deadlines that have been established for the programs' development and implementation.

Because NIPER is in the development stages of environmental programs, the assessment team primarily focused its evaluations on the effectiveness of programs during this development stage.

In general, the assessment team believes that BDM-OK is moving in the right direction and that it has demonstrated the progress expected, given the short time period it has been onsite. Therefore, no findings were identified in the environmental protection programs portion of the assessment. 


\subsubsection{Overview}

The purpose of the formality of environmental programs portion of the NIPER environmental management assessment was to determine whether formal systems and procedures are in place for BDM-OK to manage environmental compliance and for BPO to oversee and ensure BDM-OK's environmental compliance. The assessment evaluated whether formal environmental compliance and oversight activities exist at NIPER and whether these activities are documented in a consistent and formal manner. The assessment focused on the following:

- Regulatory Tracking and Translation. The systems necessary to track, interpret, and transfer DOE Orders and environmental regulations to appropriate personnel for incorporation into policies, standards procedures, and day-to-day operations.

- $\quad$ Procedures. The mechanisms by which environmental programs and procedures are developed and effectively implemented throughout the organization.

- Routine Facility Inspections. The systems for conducting routine inspections to ensure compliance with applicable environmental requirements and to identify and correct potential problems.

- Recordkeeping and Reporting. The systems for maintaining and retaining records and for ensuring timely completion of environmental regulatory and management reporting requirements.

The general approach to evaluating formality for this assessment was to review DOE Orders, environmental regulatory requirements, and background documents BDM-OK and BPO provided. Specific regulations, requirements, and guidelines used in the assessment are shown in Appendix $F$. The activities conducted onsite primarily included interviews with BDM-OK and BPO personnel responsible for environmental activities at NIPER. This included senior management, line managers, program coordinators, and staff. The entire assessment team provided input to this portion of the assessment.

Overall, because the BPO and BDM-OK operations are not conducted with the formality identified in DOE Orders, it is difficult to ensure that environmental compliance is being achieved and maintained. Plans for instituting formality have begun for BDM-OK, but the primary method of operation is currently verbal. No plans have been generated that would introduce formality into BPO programs or procedures (Finding FP-1). No serious consequences have resulted from the informality since BDM-OK became the M\&O contractor, and the site is proceeding under aggressive schedules to achieve environmental compliance.

\section{Regulatory Tracking and Translation}

The NIPER process of tracking and translation includes both DOE Orders and Federal, state, and local environmental regulations. The current method of tracking DOE Orders is 
relatively formal. DOE Orders are received by BPO and are forwarded to the BDM-OK Information Resources organization for distribution to relevant BDM-OK and BPO personnel for review and assessment of applicability. Information pertinent to environmental issues is received by the BPO environmental manager and BDM-OK environmental compliance manager. That information is then passed verbally to additional personnel. The method of tracking environmental regulations is less formal than that for DOE Orders. The method consists of the BDM-OK environmental compliance manager's reviewing the Federal Register, pertinent guidance, or other documents. Once reviewed, if any pertinent information is discovered, it is passed verbally to the appropriate personnel. No memorandums or letters are written to document the transfer of information (see Finding FP-1).

\section{Procedures}

Many procedures have not been developed because environmental programs at NIPER are in their infancy. BDM-OK's method of developing and documenting procedures, however, is relatively well established. Environmental procedures are developed primarily by the environmental compliance officer for BDM-OK. Once a procedure is developed, it is passed to the records department where a copy is maintained in a central file for easy access by all personnel. A computer database of all NIPER procedures is also maintained, but because no central computer network exists, computer access is difficult.

BPO environmental procedures are developed individually. No formal system has been established to provide guidance for procedure development and documentation (see Finding FP-1).

\section{Routine Facility Inspections}

Routine facility inspections are conducted informally. Site walk-throughs are conducted by various levels of BDM-OK and BPO management, including the BDM-OK environmental compliance officer, the BDM-OK ES\&H manager, and the BPO environmental manager (I-B-1, I-B-3, and I-B-5). Environmental issues are noted during the walk-throughs and presented to the responsible individual verbally. Typically, no formal documentation is maintained regarding specific issues (Finding FP-1).

BDM-OK and BPO have completed self-assessment plans for environment, safety, and health. The plans provide a framework for continuously improving NIPER's ES\&H program. The plans outline the individual responsibilities and requirements of personnel conducting self-assessments. The responsible personnel include the BPO director, BPO administrative contracting officer, BPO program managers, BDM-OK ES\&H manager, BDM-OK quality assurance manager, BDM-OK line managers, and other personnel with environmental responsibilities. The BDM-OK Environment, Safety, and Health Self- Assessment Plan requires that schedules for self-assessment be established at the beginning of each fiscal year and that three types of assessments be conducted. These environmental assessments include an independent assessment conducted by the quality assurance department, a management assessment conducted by the ES\&H manager and compliance staff, and a worker assessment conducted by line managers in close cooperation with the ES\&H manager and compliance staff. The BDM-OK Self-Assessment Plan also requires an annual report summarizing all self-assessment activities. Although scheduled, no selfassessments have been conducted (see Finding PE-1). 


\section{Recordkeeping and Reporting}

BDM-OK has a central recordkeeping system for maintaining environmental programs and procedures. Specific environmental documents, such as hazardous waste manifests, are maintained by the BDM-OK environmental compliance officer. BPO does not have a central recordkeeping system, but the BPO environmental manager maintains pertinent environmental documents (see Finding FP-1).

Computer databases that track compliance issues have also been developed at NIPER. The databases are the Tiger Team Reporting System (TTRS) and the BDM-OK Corrective Action Tracking System (BCATS). A line-item list of noncompliance issues is maintained in these databases. The information contained in these databases is a description of the noncompliance issue, its location at NIPER, the required completion date for corrective action, the status of corrective action, and the person responsible for corrective actions. The TTRS system contains a list of the noncompliance issues identified in the Tiger Team Assessment, and BCATS lists general issues for the entire site. Health and safety issues are maintained in these databases in addition to environmental issues. The TTRS and BCATS are useful tools that can be used to track NIPER environmental compliance issues efficiently.

The primary method of reporting issues between BDM-OK and BPO is verbal. Additionally, within both BPO and BDM-OK the primary method of reporting environmental issues to , senior management is verbal. No formal system has been established for internal communication regarding environmental issues of concern (see Finding FP-1).

One finding was identified in the formality of environmental programs portion of the assessment, pertaining to the general lack of formality established at NIPER with respect to environmental management. Formality of regulatory tracking, environmental procedures, facility inspections, and recordkeeping and reporting is, in many instances, not maintained at a level identified in DOE Orders. 


\subsubsection{Finding}

FP-1: $\quad$ Formality of Environmental Programs

Performance Objective: DOE 5480.19 "Conduct of Operations Requirements for DOE Facilities" states that effective implementation and control of operating activities are primarily achieved by establishing written standards, periodically monitoring and assessing performance and holding personnel accountable."

DOE 5480.19 directs DOE facilities to establish a routine site and equipment inspection program to ensure compliance with all relevant regulations, applicable DOE Orders, and overall performance goals.

DOE 5480.19 also states "it is the policy of DOE that the conduct of operations at DOE facilities be managed with a consistent and auditable set of requirements, standards, and responsibilities."

DOE 1324.5A, "Records Management Program," states that it is DOE policy to "maintain an active continuing program for economical, efficient, and improved management of records." It also states that it is DOE policy to "effectively control the creation or collection, organization, maintenance, use, and disposition of records in the conduct of business while complying with Federal laws and regulations."

Best management practices suggest that sitewide procedures for operations, and oversight of those operations, be formalized, implemented, and well understood by all personnel involved with these activities.

Finding: Regulatory tracking systems, environmental procedures, facility inspections, recordkeeping, and reporting are not formally or consistently documented at NIPER.

Discussion: Most environmental programs reviewed at NIPER are conducted informally, through verbal communication. The site is small, which allows for a level of direct communication between individuals that may be impossible on larger sites. This tends to promote informality because verbal communication and the resolution of environmental issues is easily conducted. Informal communication has promoted a sound working relationship between environmental personnel within BDM-OK and BPO and has streamlined the processes being developed and implemented to achieve environmental compliance. Formality of these operations, however, is lacking in many areas such that operations cannot be tracked, evaluated, and improved. Additionally, lack of formality limits NIPER's ability to substantiate day-to-day environmental compliance.

Some specific programmatic environmental formality issues presented below exemplify the lack of formality in programs evaluated for this assessment. Addressing specific formality issues noted in this assessment, however, will not necessarily result in the formality required in all environmental programs. Effective programmatic formality requires continuous facility personnel involvement. It is the responsibility of NIPER personnel and management to ensure that sufficient formality is associated with all programs and day-today operations. The specific programmatic issues assessed follow: 
A formal system has not been developed to ensure that new environmental requirements are tracked, distributed, and incorporated by BPO and BDM-OK into existing programs, policies, and procedures. BDM-OK currently receives regulatory information from various sources, but no formal process of review and distribution has been established. Additionally, information regarding DOE Orders and guidance is received by BPO from the BDM-OK Information Resources organization on a regular basis, but pertinent information is not formally reviewed or distributed by the environmental manager to appropriate BPO or BDM-OK personnel (I-B-1, I-B-3, and I-B-5). Further, when new environmental requirements are identified, formal guidance is not developed that identifies how the requirements need to be incorporated into NIPER policies, programs, or procedures.

BPO has not formalized oversight activities of BDM-OK (I-B-1 and I-B-4). A plan has not been developed that (1) outlines a schedule and procedures for conducting environmental walk-throughs, (2) establishes critical environmental compliance indicators that will be used to assess BDM-OK's compliance with environmental regulations and DOE Orders, (3) documents lessons learned, and (4) evaluates trends. Additionally, a formal definition of the oversight roles and responsibilities between environmental personnel and QA at BPO has not been established (I-E-1 and I-E-6).

- $\quad$ NIPER does not formally document the results of routine site and equipment inspections. BPO and BDM-OK conduct regular walk-throughs, but any issues discovered during these inspections are reported to the appropriate personnel verbally. No documentation is maintained, either in a file or on a computer database.

BPO has not developed a formal document-control system or recordretention policy in accordance with DOE 1324.5A to document and record environmental performance at NIPER appropriately.

- A formal method has not been established for documenting internal meetings between BPO and BDM-OK where environmental issues of concern are raised and resolved. Weekly meetings are currently held between senior BPO and BDM-OK management. If environmental issues have developed before these meetings, they are included on the senior management meeting agenda and verbally presented to BPO and BDM-OK senior managers (1-B-8). The resolution of issues, however, is not documented: it is passed verbally back to the appropriate personnel (I-B-8). Weekly meetings are also held between $B D M-O K$ and BPO environmental personnel. Issues of concern identified during these meetings and their resolution are also not documented (I-C-1, $\mathrm{I}-\mathrm{C}-4$, and $(-\mathrm{C}-6)$.

Roles and responsibilities regarding interaction and communication with regulatory agencies have not been formally defined. BDM-OK has notified various Federal, state, and local authorities regarding environmental activities at NIPER. No formal document has been developed, however, that clearly outlines the roles and responsibilities of BPO and BDM-OK for regulatory interaction (e.g., delegation of authority). 
- Regulators are informed of environmental activities conducted at NIPER, but this communication is not always documented. For example, NIPER initially contacted the Oklahoma Department of Environmental Quality (DEQ) regarding the necessity of air permits for the site. DEO indicated that no permits would be required, but formal documentation was not obtained $(1-B-1)$.

- BPO has not established a formal controlled system for creating, reviewing, updating, and approving new procedures (I-B-1).

- A self-assessment plan has been developed and approved by BPO, but implementing procedures for self-assessment activities have not been developed (1-C-24).

Overall, the lack of formality at NIPER has not resulted in any serious consequences for the site since BDM-OK became the M\&O contractor. The site is proceeding under aggressive schedules to achieve environmental compliance in many areas. The current lack of formality at NIPER does, however, make it difficult for DOE to ensure that progress toward achieving environmental compliance is proceeding appropriately and that those areas in compliance are being maintained. 


\subsubsection{Overview}

The purpose of the internal and external communication portion of the NIPER environmental management assessment was (1) to determine whether formal and informal channels of communication are effectively used to emphasize management commitment to environmental protection; (2) to promote awareness and support of environmental policies and programs throughout the organization; and (3) to share information with external organizations, such as regulatory agencies, environmental groups, and the community. The requirements and guidelines used during the assessment are shown in Appendix F.

Elements of internal communication evaluated during the assessment include regular staff meetings, management reporting, routing of key documents, distribution of an employee newsletter, and memorandums. Common perceptions of information distribution and communication effectiveness were also considered. External communication efforts that were reviewed include interaction with regulatory agencies, external public interest groups, and the general public. Communication documents reviewed include the NIPER News, press releases, internal memos, procedures, and presentation materials for public speeches.

The general approach to this portion of the assessment was to review guidance documents and background documents BDM-OK provided before the onsite portion of the assessment. Onsite activities included additional document review and interviews with management and staff within the PETC, BPO, and BDM-OK organizations, and with local and state regulatory representatives.

\section{Internal Communication}

No formal communication plan has been established; in reviewing internal communication, however, it was found that BPO and BDM-OK have established strong relationships to support the exchange of environmental information. In addition to daily informal interaction, there are weekly meetings between the BPO environmental manager and the BDM-OK ES\&H manager. The BDM-OK president holds weekly meetings with his six senior managers, including the ES\&H manager, during which each manager reports the status of ongoing activities. The BDM-OK Quality Assurance manager and the BPO QA/OC manager meet weekly. Communication of environmental issues to the BPO director occurs primarily through informal meetings with the BPO environmental manager and weekly meetings with the BDM-OK president. Informal meetings frequently occur between the BPO and BDM-OK organizations, and staff members from either organization can meet with senior management of the other organization. In addition, BDM-OK ES\&H issues a weekly report to the president of BDM-OK and a monthly technical progress report to BPO. BPO's environmental manager issues a monthly environmental report to the BPO director.

The BDM-OK ES\&H Hotline has been established to provide employees with a mechanism to communicate environmental concerns anonymously. Information about this hotline is conspicuously posted on main bulletin boards around NIPER. Each line organization staff member interviewed was aware of the availability of the hotline. 
An Environment, Safety, and Health Committee has been established. The purpose of the committee is to enhance management and employee commitment and to encourage employee involvement with the mission of protecting the safety and health of facility personnel and the public, and protecting the environment. A standard operating procedure for this committee has been approved and issued.

Memos from the director and the president have been distributed throughout NIPER; they describe the environment, safety and health policies of BPO and BDM-OK and the commitment to environment, safety and health compliance.

BDM-OK personnel at the Metairie, Louisiana, office are to be managed by the Environmental Research Program Department at NIPER. BPO has responsibility for environmental oversight of the Metairie Site Office research projects conducted at NIPER.

A good working relationship has been established with FE-30. A representative of FE-30 visits the site, and there is frequent telephone communication between FE-30 and the BPO environmental manager.

Information seems to be communicated effectively throughout NIPER, but primarily through informal means. The site is small, which allows for direct communication between individuals. Informal communication has promoted sound working relations among BDM-OK environmental and line personnel, and among BDM-OK and BPO environmental, quality assurance, and management personnel.

Some concerns related to the lack of formality of internal communication were identified (see Finding FP-1).

\section{External Communication}

There has been little public and regulatory interest in NIPER concerning environmental activities. Most external communication is managed by the BDM-OK Media \& Communications Coordinator. Information prepared by the coordinator or other BDM-OK personnel for distribution outside NIPER must be approved by the BPO public information officer. Information prepared for release by DOE must be approved by DOE Headquarters. Environmental issues and information about the NIPER programs, many of which have an environmental benefit, are occasionally addressed in external communication documents.

Since BDM-OK took over management of NIPER there have been two occasions for public participation in environmental programs at NIPER. First, DOE issued a press release relating to the Comprehensive Environmental Response, Compensation, and Liability Act Preliminary Assessment. This release was distributed to Federal, state, and local elected officials, city and state regulatory agencies, local public interest groups, and two local newspapers. The press release summarized the findings of the assessment, announced the availability of the report for review, and provided point of contacts. Second, BDM-OK notified Federal, state, and local agencies of the opportunity to observe the conduct of this environmental management assessment.

BDM-OK management and staff have made a major effort to inform the public of the activities of NIPER. BDM-OK has become very involved in public activities and frequently speaks to community and technical groups, including the Local Emergency Planning 
Committee. BDM-OK also takes an active role in community affairs and offers volunteer and financial support to various activities and causes.

A concern was identified related to the lack of formality of interface with regulatory agencies (see Finding FP-1).

Given the effective communication systems at NIPER, no findings were identified in the internal and external communication portion of the assessment. 


\subsubsection{Overview}

The purpose of the staff resources, training, and development portion of the NIPER environmental management assessment was to determine whether staff resources and training are sufficient to develop, implement, and maintain the site's environmental protection programs. The assessment evaluated the environmental training the NIPER staff receive and the staff development opportunities available for environmental personnel. Appendix $F$ includes the regulations, requirements, and guidelines used during this assessment.

The general approach to this portion of the assessment was to review DOE Orders and NIPER documents before the onsite portion of the assessment. Onsite activities consisted of reviewing additional documents obtained onsite pertaining to staff resources, training, and development. Specifically, these documents included position descriptions, performance evaluation forms, training materials, training records, position postings, and other relevant staffing procedures. Most of the time onsite was used to interview NIPER's BDM-OK and BPO staff with personnel, training, and human resource management responsibilities. Several interviews were conducted with research and development personnel and maintenance line managers to ascertain the level of environmental training support and guidance the BDM-OK ES\&H Department staff provides.

\section{Environmental Staffing}

Overall, the assessment team was impressed with the quality of environmental staff at NIPER. The education, experience, and motivation of the BDM-OK environmental staff are outstanding and are identified as a strength in this assessment (see Executive Summary). The sole BPO environmental project manager possesses the academic background, experience, and motivation to accomplish BPO's environmental oversight responsibilities.

The BDM-OK environmental staff have aggressive workloads and milestone schedules, making significant staff overtime necessary while BDM-OK addresses the numerous outstanding compliance issues under the new M\&O contract. Once the immediate environmental compliance concerns and formal documentation required by DOE Orders are satisfied, BDM-OK's overtime should gradually reduce to a point where BDM-OK's three environmental full-time equivalent employees should be capable of effectively maintaining site-wide environmental compliance with only occasional overtime. To offset the aggressive compliance schedules, the BDM-OK environmental staff has effectively leveraged subcontractors to perform environmental training and other work tasks. The use of subcontractors has been appropriate and reasonable and has not been excessive.

Aside from the ES\&H manager, BDM-OK has staffed two full-time environmental compliance officers (ECOs) assigned specifically to environmental issues. The ECOs are currently training several line personnel as environmental coordinators to provide some assistance and to shift more responsibility for environmental services to the line management organizations.

BDM-OK's environmental position vacancies are being filled with reasonable timeliness; one environmental staff vacancy was in the process of being filled, and interviews should be 
concluded within 4 weeks. The typical time required to fill a position vacancy at BDM-OK is 6 to 8 weeks (I-D-5).

BPO's environmental staff is adequate to manage its environmental oversight role of $B D M-O K$, and environmental staff support is available from PETC when necessary.

\section{Job Descriptions and Performance Evaluations}

Staffing support, as well as other personnel support activities, is obtained through the PETC Personnel Office. To date, BPO has not coordinated with PETC to update the duties within the Position Description for the BPO environmental manager that reflect consistency with appropriate duties under the current $M \& O$ contract.

Performance appraisal factors for BDM-OK environmental staff and line personnel-both exempt and nonexempt-contain specific environmental performance factors that must be supported by written justification and examples. For all BDM-OK managers, environmental performance is rated separately, and an unacceptable rating is grounds for disciplinary actions up to and including termination (I-D-1). Exceptional employee performance (including environmental performance) is rewarded in one of three separate ways: star award, excellence award, and team award. Each of these awards includes a bonus (up to $\$ 5,000)$ and formal recognition, such as a plaque, bronze star, site newspaper article (NIPER News), or special luncheon or social function. The target percentage for receiving star and excellence awards is 25 percent of the staff per year. A review of the staff awards for the current year indicated that the environmental staff is receiving recognition at the same percentage as the line staff -2 out of 8 , or 25 percent.

\section{Environmental Training Programs}

BDM-OK's environmental training programs are currently under development and slightly behind schedule based on BDM-OK's own milestones; several successful training sessions and formal classes, however, have occurred with some subcontractor assistance (e.g., First Responder Training, HAZMAT training, and environmental coordinator training). Some of these training sessions have formalized training objectives, plans, or attendance tracking systems in place, although the BDM-OK Human Resource and environmental staffs are aware of these formality shortcomings and have draft plans underway or in development (D-D-28; (-D-5).

At present the development of environmental training is the responsibility of BDM-OK's ES\&H Department, although BDM-OK's goal is to have all site training managed, tracked, and documented by the Human Resource manager. The Human Resource manager has recently tasked all BDM-OK managers to develop an individual quality management training program plan for each employee; the plan must include short- and long-term training needs, including environmental training, for employees with environment-related duties (D-D-5; $|-D-1|$.

With the assistance of the ECOS, BDM-OK managers have been developing individualized environmental training plans for their employees (I-D-9 and I-D-13). The BDM-OK line managers appear to have a good rapport and working relationship with the ECOs and expressed considerable confidence in the abilities and motivation level of the environmental staff. In one example BDM-OK's Maintenance Department manager had developed and 
implemented an employee training record and needs system (including environmental training) ahead of the site-wide system, a clear indication that environmental commitment from senior management was being effectively communicated throughout BDM-OK.

Environmental training in BPO is obtained by an individual submitting a BPO Annual Training Survey Form to the individual's supervisor and the BPO director for approval. The BPO administrative officer consolidates all the BPO training requests and forwards them to the PETC Personnel Office.

\section{Staff Development Opportunities}

BDM-OK is currently on schedule with developing its environmental staff's professional development program and has a draft Standard Operating Procedure (SOP) under review to document this program (D-D-7). The SOP requires the BDM-OK ES\&H manager to develop individual training plans and to establish minimum qualifications for each environmental staff member. Professional certification, education credentials, and continuing education credits are included in this SOP. It was not clear whether environmental managers are afforded cross-training opportunities to enter line management positions: the environmental staff were unaware of any specific opportunities or programs for this purpose.

One finding was identified in the staff resources, training, and development portion of the assessment, related to BPO management's and PETC's joint efforts' not having adequately provided input into environmental training and individual development plans for BPO's staff with environmental responsibilities. 


\subsubsection{Finding}

\section{SR-1: $\quad$ BPO Environmental Training and Staff Development}

Performance Objective: DOE Order 3410.1B, "Training," requires that all employees be provided with opportunities to improve their knowledge, skills, and abilities, and with advancement opportunities in accordance with specifically defined and approved training needs. Best management practices suggest that the organization should have a formal program in place to ensure that all personnel have received environmental training appropriate for their job responsibilities. The organization should also provide staff development and career advancement opportunities for environmental staff.

Finding: The joint efforts of BPO management and PETC have not adequately provided input into environmental training and individual development plans for BPO personnel with environmental responsibilities.

Discussion: The PETC Personnel Office provides staffing support, including management of BPO staff training and development opportunities. The BPO administrative officer acts as the site point of contact for training requests and has the responsibility for overseeing staff training and development. The PETC Personnel Office maintains and supports these activities. The senior BPO line managers are, by virtue of their defined roles, the ones most responsible for environmental training and environmental staff professional development support at BPO. The following specific deficiencies were identified with the environmental training and staff development programs:

- There is no process in place to identify and evaluate the needs for appropriate training that would provide the necessary environmental skills, career opportunities, and advancement potential for BPO personnel with environmental responsibilities. PETC has not directed BPO to ensure production of Individual Development Plans (IDPs) for BPO staff with environmental responsibilities. Further, BPO senior managers have not formally ensured that such staff produce IDPs that clearly reflect the environmental and other training necessary to accomplish BPO's mission and help improve the individual's opportunities in both the environmental arena and other areas of interest (I-D-3, I-D-8, and I-D-11).

- $\quad$ BPO is not conducting environmental awareness training for its existing staff and new employees (1-D-3).

The environmental training the BPO staff receives is self-identified. Unless it is clearly determined to be inappropriate by an individual's supervisor, the joint efforts of BPO and PETC do not adequately scrutinize BPO IDPs for similarity to the individual's previous training and relevancy to the staff member's career development. PETC maintains BPO training records and not BPO. BPO does not have easy access to these training records. IDPs are developed by BPO, and PETC does not maintain BPO IDPs with training records. Senior BPO management, however, is supportive in providing funding for training and in allowing time to pursue these training objectives, but it provides no guidance on who should be trained or what topical areas of environmental protection should be covered. 


\subsection{1 $\quad$ Overview}

The purpose of the program evaluation, reporting, and corrective action portion of the NIPER environmental management assessment was to evaluate programs that assess the design adequacy and implementation effectiveness of environmental management systems at NIPER, as well as the reporting and followup activities associated with these programs. The requirements and guidelines used during the assessment are shown in Appendix $F$.

The general approach to this portion of the assessment was to review DOE Orders, guidance documents, and background documents BPO and BDM-OK provided before the onsite portion of the assessment. Onsite activities included additional document review and interviews with management and staff within the PETC, BPO, and BDM-OK organizations.

Before 1994 NIPER was operated under a cooperative agreement between DOE and an outside contractor. The National Oil and Related Programs (NORP) were managed by BPO. The cooperative agreement did not contractually obligate the former contractor to comply with DOE Orders. As a result, elements of a formal environmental program evaluation system were not in place on November 8,1993 , when the management and operating (M\&O) contract was signed and contractor transition began. On January 1, 1994, BDM-OK took over management of NORP, including operation of NIPER, and is on a very aggressive schedule to develop a formal program evaluation system. BPO reports that implementation of its Environmental, Safety \& Health Self-Assessment Program Plan was also postponed until the $M \& O$ contract was in place.

Program evaluation roles and responsibilities for NIPER have been assigned to FE, BPO, and BDM-OK. A memo FE-1 issued on April 10, 1992, established the program evaluation roles and responsibilities for FE and BPO. Contractually, BDM-OK is required to provide other program evaluation functions. This memorandum designated FE- 6 to perform management appraisals of BPO and FE-30 to perform management appraisals of BPO and NIPER. FE has not conducted the assigned program evaluation activities for NIPER (see Finding PE-1).

\section{BPO}

BPO was assigned the responsibilities to perform internal appraisals of BPO, self-appraisal and self-assessments of BPO, and management and functional appraisals of the NIPER contractor. The BPO self-assessment plan was approved April 1992. The document presents the plan for internal, management, functional, and external appraisals. The plan commits BPO to perform tasks to implement a comprehensive environmental selfassessment and appraisal program. Activities have not been conducted in accordance with the plan (see Finding PE-1).

Preparation of implementing procedures for BPO's Self-Assessment Program Plan was initiated, but it was postponed until the M\&O contract was in place. It was expected that the terms of the contract might affect BPO's oversight responsibilities. Work on these procedures, however, has not resumed since the contract was signed. Procedures are expected to include scheduling, team selection, reporting, protocols, documentation, and 
corrective action. The lessons-learned program is expected to incorporate all oversight activities rather than just self-assessment.

The only ongoing BPO program evaluation mechanism is walk-throughs that occur approximately once per week to monitor NIPER environmental compliance. The results of this activity are not recorded by BPO but are reported orally to the BDM-OK ES\&H manager in a weekly meeting. Major non-compliance issues identified during the weekly walkthroughs would be reported to the program coordinator for Advanced Extraction and Process Technology and the BPO director.

The BPO Office of Quality Assurance/Quality Control was established in October 1993. Independent program assessment of the BPO ES\&H self-assessment program is a line item in the BPO Quality Assurance (OA) Five-Year Plan, but a milestone for completion of this assessment has not been established.

Several DOE contractors conduct research offsite for NORP. BPO is not providing environmental oversight of these offsite research projects (see Finding PE-1). A project to evaluate the ES\&H and QA responsibilities for offsite research is described in the draft Five Year Oil Implementation Plan Report, including milestones (D-C-36). The program is to be initiated in fiscal year 1995.

In addition, the findings related to BPO's environmental program evaluation activities, which were identified in the May 1992 report of the Tiger Team Assessment, have not been corrected.

\section{BDM-OK}

The BDM-OK Environmental, Safety, and Health Self-Assessment Plan was approved in May 1994. A schedule for preparation of implementing procedures is presented in the Comprehensive Environment, Safety and Health Program Implementation Plan. Five types of evaluation activities are described in the plan: independent, management, and worker assessments; ES\&H self-assessment; and informal ES\&H workplace visits. The responsibilities of PETC, BPO, and BDM-OK employees are also described. Procedures for self-assessments, corrective action management, and lessons learned will be developed to implement the program.

BDM-OK OA is responsible for conducting independent assessments and assisting BDM-OK ES\&H in developing its assessment program. A draft procedure for independent assessments is under review, and $O A$ has conducted an independent assessment of hoisting and rigging, but none of an environmental program. QA has also drafted procedures for a DOE Tiger Team Closure Plan and for the use of outside training for the certification of auditors. It has begun work on a scheme for subcontractor performance evaluations as well.

An ongoing BDM-OK environmental program evaluation activity is the weekly informal ES\&H workplace visits conducted by the BDM-OK environmental compliance officer. Deficiencies are discussed with the responsible individual at the time of identification and are generally corrected immediately. The results of these activities have not been recorded in the BCATS system or documented in any other manner (see Findings FP-1 and PE-1). 
Ongoing self-assessment of the environmental activities in the line organizations will be conducted by environmental coordinators. Several environmental coordinators have been designated, and the first training session has been conducted for these personnel. The draft procedure for Environmental Coordinator Qualification will be circulated for review and comment.

Several major environmental program evaluation activities have occurred since the management and operating (M\&O) contract was signed. At the request of BDM-OK, Geraghty and Miller conducted an independent baseline assessment of environment, safety, and health programs at NIPER. In January an internal BDM-OK ES\&H assessment team of BDM-OK lead researchers and BDM-Federal compliance was formed to look at the general condition of the laboratories and chemical management. In July 1994 Geoscience Consultants, Ltd., conducted an independent review of BDM-OK's hazardous waste management program. Findings were prioritized. The correction of safety and health findings is receiving top priority and is being tracked in the BDM-OK Corrective Action Tracking System (BCATS). Some corrective action activities are underway for environmental findings and observations, which are now being entered in BCATS.

The assessment team identified BCATS as a strength. It was developed to track several types of findings, including management and environmental findings. Standard references, performance objectives and criteria, risk codes, and a completion date for a finding are printed automatically, based on entry of assigned "checklist item ID," severity code, and probability code into the database. At present, one person assigns the severity and probability codes to ensure consistency. Performance objectives and criteria, which were prepared by the DOE Office of Environment, Safety and Health, are part of the system database. The system is designed to facilitate identification of trends. Root cause analysis has been temporarily deleted from BCATS until personnel who might be expected to do this analysis have been trained. The system is currently used on a personal computer, but the plan is to provide wide access to BCATS through a local area network (LAN). A training program has been developed for data entry, and six BDM-OK employees have been trained. This training will be expanded when the LAN system is in place. Some limitations in BCATS have been identified and are being addressed.

Oversight of environmental programs and of BDM-OK subcontractors performing research for NORP is the responsibility of the BDM-OK ES\&H manager. A project to evaluate the ES\&H and OA responsibilities for offsite research is described in the draft Five Year Oil Implementation Plan Report, including milestones (D-C-36). The program is to be initiated in fiscal year 1995.

Development and implementation of the BDM-OK environmental program evaluation activities is progressing according to an aggressive schedule. It seems appropriate that implementation of health and safety evaluation and corrective action has received priority because of the nature of the findings to date in the health and safety area. BDM-OK is actively working on correcting the contractor deficiencies identified during the 1992 Tiger Team assessment. Its program evaluation activities do not at this time include all elements expected to be evident in a strong environmental self-assessment and appraisal program. The elements have been identified, however, and plans are in place to develop and implement these elements. Appropriate progress is being made. 
One finding was identified in this section of the report, relating to deficiencies in implementation of the self-assessment and appraisal programs of FE, BPO, and BDM-OK. 


\subsection{2 $\quad$ Finding}

PE-1: $\quad$ NORP Environmental Program Evaluation

Performance Objective: DOE 5482.1B, "Environment, Safety and Health Appraisal Program," assigns responsibility for certain appraisal activities to the Cognizant Secretarial Officials, Heads of Field Organizations, and operating levels; it also defines implementation procedures.

In March 1992 the FE Office of Self-Assessment (FE-6) issued a self-assessment program plan. This plan required DOE Field Organizations and contractors to perform and document environmental appraisals in accordance with an approved schedule, and it defined the specific types of appraisals for each organization.

In an April 10, 1992, memorandum, $\mathrm{FE}-1$ established the program evaluation roles and responsibilities for $\mathrm{FE}$ and $\mathrm{BPO}$.

Best management practices suggest that organizations adhere to commitments in their program plans.

Finding: For the National Oil and Related Programs (NORP), which includes NIPER, environmental program evaluation activities have not been fully implemented in accordance with DOE 5482.1B, FE guidance, and best management practices.

Discussion: Environmental program evaluation activities for NORP have been assigned to $\mathrm{FE}, \mathrm{BPO}$, and BDM-OK, and implementation of these activities varies among the three organizations. Although a number of program evaluation activities have taken place at NIPER, problems were identified with each of the programs, as discussed below.

FE

The April 10, 1992, Assistant Secretary for Fossil Energy (FE-1) memorandum assigned environmental roles and responsibilities for NIPER operations to FE (D-C-11). FE-6 is directed to perform management appraisals of $\mathrm{BPO}$, and FE-30 is directed to perform management appraisals of BPO and NIPER. To date, these appraisals have not been conducted (I-C-6).

$\underline{B P O}$

Self-assessment activities required by the April 10,1992, memorandum and described in the April 1992 BPO Environmental, Safety \& Health Self-Assessment Program Plan have not been conducted $(D-C-29 ; 1-C-6)$. The plan presents the mechanism for internal appraisals of BPO, management and functional appraisals of the contractor, and the plan for using the results of evaluations conducted by independent organizations for external appraisals. The approved plan commits BPO to prepare implementing policies and procedures, update audit guides and training material, prepare a computer database system to track implementation of corrective actions, and prepare summaries or briefings for BPO and NIPER managers to inform them of findings, progress, and status of corrective actions. 
Formal submissions related to environmental appraisal programs are required by DOE 5482.1B. A schedule showing the functional and management appraisals planned for fiscal year 1995 should have been submitted to FE-1 and EH-1 by August 1, 1994, but was not (I-C-6).

Since the 1992 Tiger Team assessment, environmental program evaluation by BPO has been limited to informal walk-throughs. These walk-throughs occur approximately once per week, and in general they are inspections of waste management areas. The results are not documented, and reporting occurs during weekly meetings with the BDM-OK ES\&H manager (I-C-1 and $1-C-6)$. Since the results are not being tracked, trends analysis cannot be done, nor can BPO be assured that all deficiencies have been corrected and that root causes have been identified and corrected (see Finding FP-1).

Several DOE contractors conduct research offsite for NORP, but BPO is not providing environmental oversight of these offsite research projects $(1-C-6)$. A project to evaluate the environmental, health, and safety (ES\&H) and quality assurance (OA) responsibilities for offsite research is described in the draft Five Year Oil Implementation Plan Report, including milestones (D-C-36). The program is to be initiated in fiscal year 1995.

\section{BDM-OK}

One of BDM-OK's key ongoing environmental program evaluation activities is the weekly "informal ES\&H workplace visits," conducted by the BDM-OK environmental compliance officer. Deficiencies are discussed with the responsible individual at the time of identification and are generally corrected immediately. The deficiencies are not recorded in the BCATS system or documented in any other manner (I-C-3). Since the results are not being tracked, trends analysis cannot be done, nor can BDM-OK be assured that all deficiencies have been corrected and that root causes have been identified and corrected (see Finding FP-1). 


\subsubsection{Overview}

The purpose of the environmental planning and risk management portion of the NIPER environmental management assessment was to evaluate the extent to which environmental planning is conducted and integrated into the overall planning process at NIPER. The adequacy of the approach BPO and BDM-OK use to identify, evaluate, and mitigate environmental risks was also reviewed. The DOE Orders, Federal and state regulations, and guidelines used in the assessment are provided in Appendix $F$.

The scope of the environmental planning portion of the assessment included short- and long-term planning, technical and financial planning integration, resource allocation, and projects prioritization. The scope also included the adequacy of funding for environmental protection programs; the relative priority that environmental issues are given, compared with research and development, in the planning and budgeting process; and the adequacy of planning for needs in the area of pollution control technology and related equipment.

The scope of the risk management portion of the assessment included addressing the adequacy of the site's environmental hazard identification system and evaluating NIPER's process of minimizing and mitigating environmental hazards. The procedure included reviewing risk management program content and approach, the site's risk-based prioritization system, and the documentation that supports the entire process.

The general approach to this portion of the assessment was to review documents provided to the assessment team, review applicable DOE Orders, Federal and state regulations, and other background material before the onsite portion of the assessment. Once onsite, the team gave most of its attention to interviewing BPO and BDM-OK staff who have roles and responsibilities in environmental planning and risk management and reviewing documents that were received during the interviews. Key personnel interviewed included senior line managers, environmental compliance staffs, accounting and finance personnel, and research and development staff for BDM-OK and BPO.

The key documents reviewed included environmental strategic plans, activity data sheets for environmental initiatives, the Comprehensive ES\&H Program Implementation Plan, the Environmental Monitoring Plan, and the NIPER ES\&H Management Plan.

\section{Environmental Planning and Budgeting}

BDM-OK is proceeding approximately on schedule with its environmental planning process. The process by which NIPER undertakes environmental planning is described in the ES\&H 5-Year Management Plan (1996-2000), Comprehensive ES\&H Program Plan, and the Comprehensive ES\&H Program Implementation Plan. BDM-OK is planning to develop risk management and associated quality assurance plans that discuss the site's formal environmental planning process. The general lack of formalized environmental planning performed by the previous contractor under the cooperative agreement resulted in BDM-OK's having to establish a complete environmental planning "baseline" since the first of the calendar year. 
NIPER's environmental planning strategy and priorities list originated from two distinct sources: the Tiger Team Report and the December 1993 site-wide ES\&H review that occurred before BDM-OK commenced site operations. The findings from these sources were the genesis of the ES\&H 5-Year Management Plan, a collection of Activity Data Sheets (ADSs) that delineate the initial budget estimates, staffing needs, and program direction from a resource perspective. The Comprehensive ES\&H Program Implementation Plan (D-D-32) integrates milestone schedules, project plan steps, and assigned responsibilities into an overall plan for obtaining compliance with environmental regulations and DOE Orders. BDM-OK's ES\&H manager has the responsibility for integrating the ADSs and proposing funding, staffing, and priorities to the president of BDM-OK, who has the ultimate corporate-approval authority. The final environmental plan recommendations are submitted to BPO in the Annual ES\&H Management Plan. BPO uses this plan in the budget process to measure BDM-OK progress toward meeting the agreed environmental goals. BDM-OK stated that the Annual ES\&H Management Plan will be updated and resubmitted to BPO each year (I-D-5).

Progress in meeting environmental goals and milestones is evaluated monthly under the terms of Appendix B of the M\&O contract, "Reporting Requirements Checklist," and discussed in weekly meetings between the BDM-OK ES\&H manager and the BPO environmental manager. This information is summarized in the deliverable called the "Monthly Project Status Report" under the Management and Operating Contract of the National Oil and Related Program. This monthly report includes a brief description of any technical approach changes and summary status forecasts, followed by Cost Management Summaries and Reports by element code (program elements) for the reporting period and cumulative to date. Environmental activities are included in this report as reporting elements under both the Core and Corrective Action funding lines.

\section{Risk Management}

The assignment of risk-based priorities to specific environmental projects is conducted systematically, and the overall process maturity appears to be progressing at a satisfactory rate, given the short time the M\&O contract has been in place. BDM-OK is currently planning to document this process in mid-fiscal year (FY) 1995. The algorithm used to rank environmental risks at NIPER was extracted from the DOE guidance manual, ES\&H Management Plan for 1996-2000, November 1993, which uses a risk matrix for the probability of occurrence and the severity of outcome for the occurrence and then assigns a numerical score to the matrix cell location of the activity. BDM-OK is required to revise its risk-based prioritization annually but has tentative plans to review the prioritization at quarterly intervals.

The priorities established by this process are reasonable and prudent. Imminent safety and health projects dominate the top of the priority list, followed by disaster preparedness items and then by environmental compliance projects. Within the environmental corrective action projects, the Tank Farm Protection and Compliance, Toxic and Hazardous Chemical Inventory Compliance, and RCRA Compliance projects top the priority list. This ranking is reasonable, given the known environmental hazards onsite.

Funding for environmental corrective action projects appears reasonable and is expected to increase from $\$ 1.35$ million in FY 1994 to $\$ 1.9$ million in FY 1995 . The environmental schedule established in the NIPER Comprehensive ES\&H Program Implementation Plan is 
aggressive. BDM-OK is projecting an \$8.6 million budget for FY 1996 corrective-action projects. BDM-OK's projected corrective actions appropriately reflect the funds provided for such environmental activity.

As required by DOE Orders 5480.19 and 5440.1E, BDM-OK has drafted a Standard Operating Procedure (SOP), "ES\&H Review of Programs and Projects," that details how the environmental impacts and risks associated with new research and development (R\&D) projects are being assessed. The draft SOP requires environmental review of programs and projects conducted by NIPER, both on- and offsite, and establishes a work planning and execution process that should ensure that environmental risks and compliance objectives are identified in the earliest possible stages of the R\&D effort.

This draft SOP requires line R\&D managers to complete and submit an environmental checklist to the appropriate BDM-OK environmental compliance officer (ECO) for analysis. The ECOs will in turn determine the extent and severity of the environmental risks; determine what NEPA documentation is required; develop budget input for environmental compliance activities and pollution abatement equipment; and develop alternatives for reducing these risks, including chemical substitutions, waste minimization, and process controls or changes.

The M\&O contract currently allows 10 work days for a proposal response to PETC/BPO once an R\&D Work Order Request is issued. $R \& D$ line managers usually require the full 10 days to develop the technical proposal, which sometimes does not allow the ECO adequate time to evaluate the environmental risks fully and to develop budget estimates and mitigation strategies. The BDM-OK ECO is actively working with line managers to improve the ES\&H R\&D project review process (I-D-9).

One finding was identified in the environmental planning and risk management portion of the assessment, related to the fact that the BPO environmental manager is not provided financial reports detailed enough to track expenditures and financial progress to the project level. 


\subsubsection{Finding}

\section{RM-1: $\quad$ Environmental Project Expenditure Oversight}

Performance Objective: Best management practices suggest that organizations should plan for environmental management activities to ensure that environmental resource needs are adequately addressed and the organization's environmental goals and priorities are met. Commitment of funds for environment-related activities should serve the organization's environmental performance goals through capital and maintenance projects.

Finding: BPO's oversight of environmental project expenditures does not ensure that the commitment of environmental funds serves NIPER's environmental performance goals.

Discussion: The NIPER Comprehensive ES\&H Program Implementation Plan delineates the site's environmental project priorities based on a risk-ranking system that reflects the organization's environmental goals and objectives to mitigate environmental risks (D-D-41). Approximately 20 environmental projects on the NIPER Corrective Action priority listing are currently receiving some degree of funding. The BPO environmental manager, through the authority of the principal contractor officer representative, is responsible for ensuring that the commitment of environmental funds is consistent with the established environmental goals and priorities and that the greatest portion of funds is committed to the environmental projects having the highest priority and bearing the greatest environmental risk. By contrast, the PETC Administrative Contracting Officer is responsible for ensuring that aggregate environmental expenditures by the M\&O contractor are obligated on schedule and do not exceed the total funds obligated for environmental corrective actions. PETC's financial tracking system does not consider individual environmental project expenditures.

The M\&O contractor's (BDM-OK's) performance under the Operating Contract of the National Oil and Related Program, Appendix B, "Reporting Requirements Checklist," requires that cost management reports by program elements be provided in the Monthly Project Status Report. BDM-OK's Accounting and Finance Department is responsible for producing cost management reports. These reports show the accrued costs for the current month and cumulative-to-date costs for each of the major reporting elements, which include environmental core and corrective action. The cost data for each environmental reporting element is an aggregate cost and does not provide the accrued costs for individual projects. This creates the following shortcomings in BPO oversight effectiveness:

- BPO cannot determine to what extent the allocated funds have been obligated among the 20 environmental projects (D-D-36; I-D-3 and I-D-10).

- BPO cannot determine whether projected funding requirements generated in the environmental planning process for specific environmental activities were overestimated or underestimated or whether projected requirements need to be modified or shifted during the fiscal year.

- The inability to generate project funds commitment data impedes BPO's ability to make accurate environmental budgeting projections in future years and diminishes BPO's ability to validate BDM-OK budget submissions. 
Interviews with finance staff from BDM-OK and BPO indicate that financial reports that allow the tracking and oversight of environmental funds down to the project level may be available but have not been requested (I-D-7 and I-D-10). BPO's management stated that this shortcoming in BPO's environmental planning and risk management program would be addressed in FY 1995 (I-D-12). 


\subsubsection{Overview}

The purpose of the quality assurance (OA) portion of the NIPER environmental management assessment was to evaluate the level of development and implementation of the sitewide Quality Assurance Program and its application to environmental control and management. The assessment evaluated the extent to which the programs under development reflect relevant Federal regulations and DOE Orders, as well as accepted industry $O A$ practices and standards of performance. The specific $Q A$ regulations, requirements, and guidelines used in the assessment are shown in Appendix F.

The general approach to this portion of the assessment was to review DOE Orders, regulatory requirements, and background documents NIPER provided before the onsite portion of the assessment. Onsite activities focused primarily on interviewing key personnel involved with the development, implementation, management, and oversight of the Quality Assurance Programs at BPO and BDM-OK. Additional QA documents, plans, procedures, and records, not supplied during the presite period, were also reviewed.

During the assessment, the QA.specialist coordinated efforts with each of the management specialists to ensure that environmental management issues such as program formality, functional responsibilities, interfaces, and oversight were evaluated with respect to quality assurance programs required by DOE 5700.6C. Issues identified with respect to these programs were incorporated into the discussions in the environmental management areas (see Finding FP-1).

At NIPER the environmental QA program is an integral part of the sitewide QA program. $B D M-O K$ and BPO share responsibility for $Q A$, each having its own separate $Q A$ program.

The BDM-OK Quality Assurance Program is currently undergoing development and implementation. In the eight months since BDM-OK assumed management and operating responsibility for NIPER, the BDM-OK Quality Assurance Department has generated the Quality Assurance Program Plan, the Quality Assurance Implementation Plan, and the Quality Assurance Assessment Plan. Implementing procedures are being developed: the first $Q A$ operating procedures are scheduled to be in place October $1994(1-E-8)$. While principal responsibility for QA within BDM-OK rests with the OA Department, there is a close working relationship with the BDM-OK ES\&H Department. The frequent interaction between these departments has ensured that environmental requirements are addressed in the QA program. Although it is too early to evaluate the effectiveness of the BDM-OK QA Program, the implementation schedule is aggressive and the implementation actions should result in the timely implementation of an effective $Q A$ program. The first areas being targeted for implementation are the assessment program and calibration program.

Although BPO has been in existence for more than a decade, it began development of its QA program in 1992. A rudimentary draft quality plan was generated in 1992, and the formal Quality Assurance Program Plan is currently awaiting the BPO Director's approval. Because of the absence of any $Q A$ guidance from FE and the nature of the cooperative agreement under which NIPER was operated by the previous site contractor, where the contractor was not required to meet the requirements of any DOE orders, BPO did not fully understand the need for a QA program for its own operation. Since 1993 there has been 
an employee within BPO with full-time QA responsibility. BPO currently has a quality assurance/quality control program under the direction of the Office of Quality Assurance/Quality Control (OA/OC) manager. The manager has initiated weekly meetings with the BDM-OK OA manager and staff. The BPO QA/OC manager maintains a close working relationship with the BPO environmental staff. In developing the BPO QA program, the QA/OC manager has been researching a variety of OA regulations, laws, standards, and implementation guides, including the draft consensus standard for environmental $Q A$, to develop a program that not only meets current needs, but also seeks to accommodate future requirements such as 10 CFR 830.120 , ISO 9000 , or ANSI NCSL540-1. BPO has not yet developed implementing procedures but has an informal implementation plan and schedule. The BPO QA/OC manager monitors BDM-OK OA Program implementation milestones at the weekly BPO/BDM-OK OA meetings. Although the roles and responsibilities for oversight of BDM-OK environmental activities by BPO have not been formalized, the BPO OA/OC manager and the BPO environmental manager are working together in a manner that permits oversight without conflict or redundancy.

The strength in the NIPER QA Program is its personnel. BPO and BDM-OK QA and environmental management and staff are working together to develop and implement a $Q A$ program that not only meets current requirements but also proactively addresses future quality needs. Because NIPER is undergoing QA program implementation and the implementation is currently on schedule, no findings were identified in the quality assurance portion of the assessment. 


\section{APPENDIX A}

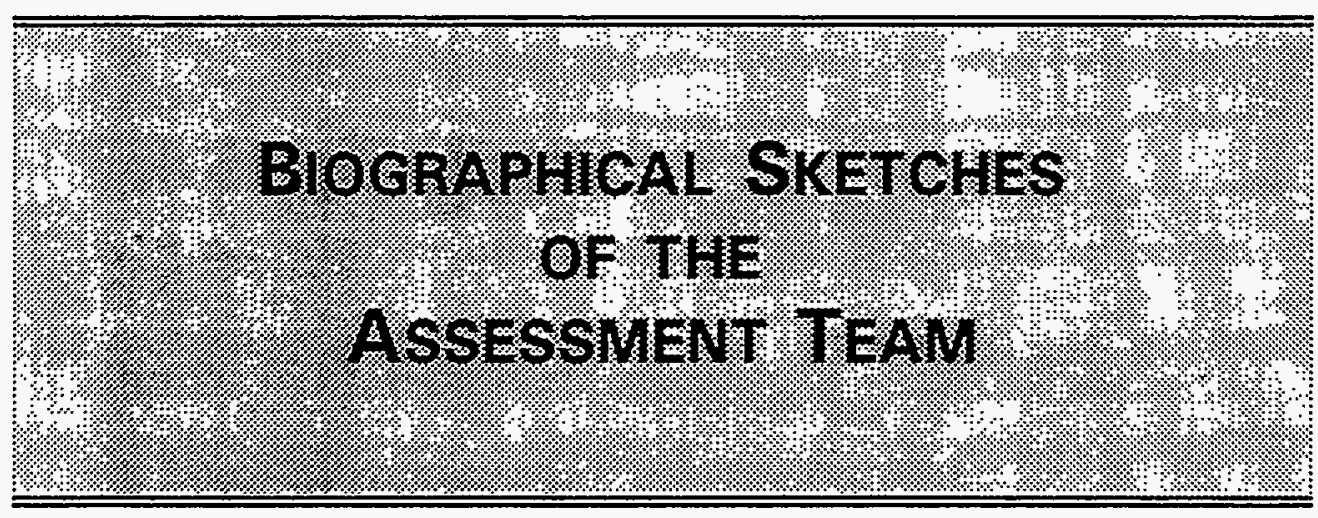


Page intentionally blank 
NAME:

Richard S. Green

AREA OF RESP: Team Leader

ASSOCIATION: U.S. Department of Energy

EXPERIENCE: $\quad 21$ Years

- U.S. Department of Energy, Office of Environmental Audit

- Team Leader responsible for conducting audit activities and providing guidance, direction, and assistance to a multidisciplined group of professionals performing environmental auditing activities at DOE facilities.

- Served as the Team Leader for the routine environmental audit of the Pinellas Plant; Deputy Environmental Subteam Leader for the Fermilab Tiger Team assessment; Deputy Team Leader for the CEBAF and WIPP environmental management assessments, and ITRI environmental baseline audit; and Environmental Specialist for the EM-20-sponsored INEL agreement-in-principle review.

- U.S. Department of Energy, Office of Environmental Compliance

- Compliance Coordinator responsible for conducting independent oversight of environmental compliance activities at the Savannah River Site.

- U.S. Environmental Protection Agency, Office of Waste Programs Enforcement

- Environmental Protection Specialist (EPS) responsible for providing assistance in technical case development to EPA Region 6 and conducting oversight of Region 6 enforcement-lead Superfund sites.

- U.S. Environmental Protection Agency, Office of Compliance Monitoring

- $\quad$ EPS responsible for the development of Toxic Substances Control Act (TSCA)/Federal Insecticide, Fungicide, and Rodenticide Act (FIFRA) enforcement penalty policies and monitoring strategies, and for the revisions to the TSCA and FIFRA Good Laboratory Practice Regulations.

- U.S. Environmental Protection Agency, Office of Toxic Substances

- $\quad$ EPS responsible for the management of multidisciplined groups of professionals tasked to assess the risks and the appropriate regulatory dispositions of chemical substances subject to TSCA.

- U.S. Environmental Protection Agency, Office of Pesticide Programs

- $\quad$ EPS responsible for the management of multidisciplined groups of technical professionals tasked to assess insecticide products subject to the FIFRA registration process.

EDUCATION: $\quad$ B.S., Entomology, University of Maryland ` 
NAME:

GeriAnne Carrales

AREA OF RESP: Technical Assistance and Audit Team Member (Student Intern)

ASSOCIATION: U.S. Department of Energy

EXPERIENCE: $\quad 2$ Months

- U.S. Department of Energy, Office of Environmental Audit

- Provided technical assistance for the daily operations of the Office of Environmental Audit at both DOE Headquarters and field locations.

- San Diego Unified School District

- School librarian responsible for library management, including recruiting and training 20 assistants, planning and implementing student programs, and training teachers in use of computer automated systems.

- Independent Small-Business Owner

- Owner/manager of coin laundry business; responsible for daily operations including daily receipts, maintenance, customer relations, bookkeeping, budget projections, advertising, etc.

- Scripps Ranch Swim and Racquet Club

- Teacher/Director for Adventure Park Preschool; responsible for daily programs and record keeping for 36 children (2-6 years), compliance with state licensing requirements, and work schedules and details for 3 assistants.

EDUCATION: $\quad$ M.Ed., Leadership and Administration, University of San Diego (in progress)

B.A., Liberal Studies, Cal State San Marcos 
NAME: Joseph Delaney

AREA OF RESP: Team Coordinator

ASSOCIATION: Arthur D. Little, Inc.

EXPERIENCE: $\quad 9$ Years

- $\quad$ Arthur D. Little, Inc.

- Surface water/drinking water specialist for the Tiger Team assessments of the Naval Petroleum Reserves in California, the Pittsburgh Energy Technology Center, the Strategic Petroleum Reserve, and Fermilab; inactive waste sites specialist for the Tiger Team assessment of the Naval Petroleum and Oil Shale Reserves; environmental protection programs and formality of environmental programs specialist for the environmental management assessment of the Continuous Electron Beam Accelerator Facility and the routine environmental audit of the Pinellas Plant; program evaluation, reporting, and corrective action specialist for the environmental management assessment of the Waste Isolation Pilot Plant. Assisted on the Tiger Team assessment of the Stanford Linear Accelerator Center.

- Revised Performance Objectives and Criteria (POCs) for the Department of Energy Environmental Audit Program. Responsibilities included revising surface water and soil, sediment, and biota POCs.

- Participated in numerous environmental audits for commercial clients. Specialized in the assessment of compliance with provisions of the Clean Air Act, Clean Water Act, Resource Conservation and Recovery Act, and Safe Drinking Water Act.

- Prepared a Toxic Substances Control Act (TSCA) training manual to address the major provisions of TSCA, including asbestos and polychlorinated biphenyl (PCB) management.

- Environmental Consultant

- Conducted a variety of studies assessing the impact of process wastewater discharges on receiving water quality. These studies included characterization of waste streams, thermal impact assessment, and water quality modeling in support of National Pollutant Discharge Elimination System permit applications.

- Participated in several sampling programs for the Army Corps of Engineers to assess PCB releases and dredge material disposal sites.

- Prepared and updated Spill Prevention Control and Countermeasure Plans and Emergency Response Plans to address oil and hazardous materials spills from several industrial sites.

EDUCATION: B.S., Civil Engineering, Northeastern University

OTHER: Registered Professional Engineer 
NAME: Lee Carpenter

AREA OF RESP: Technical Editor

ASSOCIATION: Development Technologies, inc.

EXPERIENCE: $\quad 9$ Years

- Development Technologies, inc.

- Technical Editor, providing support to the Department of Energy, Office of Environmental Audit, in conducting environmental assessments of DOE sites. Participated in the routine environmental audit of Sandia National Laboratories, California, and the Lawrence Livermore National Laboratory.

- The Library of Congress

- Editor-in-Chief of In Focus, a divisional organ of the Library of Congress Photoduplication Service. Delegated article assignments, copy-edited submissions, pasted up layout, and supervised the printing.

- System Administrator of a monitoring database. Assisted in writing the application in Paradox 3.5, meeting regularly with division section-heads and Library management to ensure suitability of the completed system and to report on production progress. Trained staff to use the system and performed regular system maintenance.

- Senior administrative clerk, providing information on Library services to Congressional offices, university libraries, and the public.

- Freelance Author and Editor

- Style consultant to PC Magazine

- Author of "Today's Music," a weekly column on the music of the Church of the Ascension and St. Agnes in Washington, DC.

- Contributing editor of The Ace Occasionally, a contemporary arts magazine.

- Assistant to colleagues at the Library of Congress, helping with style considerations in the production of reports, memorandums, résumés, and the like.

- Style consultant to Tax Analysts for their daily publication Tax Notes.

- Style consultant to the Washington Conservatory of Music.

EDUCATION: $\quad$ Gallaudet University; Washington, DC

St. John's College; Annapolis, MD 
AREA OF RESP: Environmental Protection Program; Formality of Environmental Programs

ASSOCIATION: Arthur D. Little, Inc.

EXPERIENCE: 9 Years

- $\quad$ Arthur D. Little, Inc.

- Participated in Tiger Team assessment of the Stanford Linear Accelerator Center facility and the baseline environmental audit of the Nevada Test Sites Offsite Areas.

- Participated as member of a large team assembled to conduct a preliminary environmental assessment of a large natural gas field in Kazakhstan.

- Served as technical expert on a team conducting due-diligence assessments on various mining facilities in Chile.

- Assisted in a due-diligence audit for the Environmental Protection Agency (EPA) with regard to a large real estate transaction in Michigan, for the potential development of a research facility.

- Managed oversight of Navy RI/FS activities at the Naval Construction Battalion Center in Davisville, RI, in support of the EPA under an Arthur D. Little contract.

- Performed technical review of preliminary site assessments for real estate transactions in Massachusetts to ensure compliance with state regulations.

- Managed human health risk assessment studies being conducted for various Region I Superfund sites under an Arthur D. Little EPA contract, and managed studies conducted by the U.S. Army.

- Assisted in the development of a mathematical hazard-ranking model and conducted its application. The model was based on risks posed to human health and the environment near hazardous waste sites. The sites were also ranked using the EPA hazard-ranking system.

- - Managed site characterization project in New Jersey, consisting of collection, analysis, and assessment of data to determine whether the site could be considered clean under New Jersey (ECRA) and Federal (CERCLA, SARA, and $R C R A$ ) regulations.

EDUCATION: $\quad$ M.S., Geophysics, Boston College

B.S. Geology, Allegheny College 
NAME:

Rana K. Gupta

AREA OF RESP: Environmental Commitment; Organizational Structure

ASSOCIATION: $\quad$ Arthur D. Little, Inc.

EXPERIENCE: $\quad 5$ Years

- Arthur D. Little, Inc., Cambridge, MA

- Served as Technical Specialist in the areas of environmental commitment and formality of environmental programs for the management systems assessment of $\mathrm{K}-25$.

- $\quad$ Facilitated an Environmental, Health and Safety (EHS) audit for a U.S. multinational firm with operations in Singapore, China, Taiwan, and Hong Kong. Provided regulatory documentation and analysis for ESH audits to be conducted in facilities in each of the countries. In addition, acted as liaison between Arthur D. Little staff in Taiwan and client in U.S. for pre-audit arrangements and logistics.

- $\quad$ Assisted in the project management of a country-wide, due-diligence project involving 25 facilities: Responsibilities included providing home-base support and logistical aid to teams in the field, working with laboratories responsible for analyzing paint, radon, and water samples, editing reports, acting as liaison with client, and preparing final drafts for the client.

- Assessed two facilities, an incinerator and a wastewater treatment plant, for Arthur D. Little Site WATCH ${ }^{\circledR}$ reports. Through interviews and document review, areas such as environmental management systems and organizational structure were analyzed: Also performed financial statement analysis of the owner-companies to determine financial resource capabilities.

- Participated in an environmental compliance audit of a U.S. chemicals packaging and distribution facility; the audit focused on the facility's air, water, waste and emergency response compliance status.

EDUCATION: $\quad$ M.B.A., Finance/International Business, New York University M.S., Operations Research, Stanford University

B.A., Mathematics, Earlham College 
NAME:

Edward F. Maher, Sc.D., CHP

AREA OF RESP: Staff Resources, Training and Development;

Environmental Planning and Risk Management

ASSOCIATION: ， Arthur D. Little, Inc.

EXPERIENCE: $\quad 21$ Years

- $\quad$ Arthur D. Little, Inc.

- Senior Consultant, Certified Health Physicist, and Manager of the Radiation

Technology and Policy Unit, providing technical and managerial support for

DOE assessments and audits and for various other government and commercial clients involving environmental management, health physics, environmental quality and risk estimation.

- Participated in the routine environmental audits of the Pinellas Plant, the Hanford Site, the Nevada Test Sites Offsite Areas, and the Lawrence Livermore National Laboratory.

- $\quad$ United States Air Force (USAF), Armstrong Laboratory, Brooks AFB, TX

- Chief, Bioenvironmental Engineering Division. Overall manager and director of comprehensive environmental and occupational health services support to worldwide USAF installations. Responsible for the overall management and technical content in the specialty areas of air and water quality, environmental and occupational health physics, hazardous waste and material management, and environmental noise.

- USAF Occupational and Environmental Health Laboratory, Brooks AFB, TX

- Chief, Radiation Services Division. Overall director and provider of a wide range of health physics support to worldwide USAF installations. Support included environmental and occupational radiological protection consultation and field investigations, radioanalytical laboratory services, radiation dosimetry, radioactive source permitting and transportation safety, radiological accident contingency response planning and risk assessment. Directed the Air Force's Radiation Assessment Team (AFRAT) that provided immediate and global response to nuclear weapon accidents and mishaps in concert with DOE's Accident Response Group.

- USAF Electronics Systems Division, Hanscom AFB, MA

- Chief, Environmental Health Section. Responsible for providing comprehensive industrial hygiene, environmental engineering, public health, and radiological protection services to the base community and acquisition centers.

- USAF School of Aerospace Medicine, Brooks AFB, TX

- Project Scientist, Laser Effects Branch. Conducted experimental-based research and modeling studies in ocular laser damage and bioeffects of ultrashort pulsed lasers and broad-band optical hazard sources; developed laser exposure standards for adoption by the USAF Surgeon General.

EDUCATION: $\quad$ Sc.D., Radiological Health and Protection, Harvard University M.S., Biomedical Engineering, Worcester Polytechnic Institute

B.S., Electrical Engineering, Lowell Technological Institute 
NAME: $\quad$ James W. Melloni, Jr.

AREA OF RESP: Environmental Protection Programs;

Formality of Environmental Programs

ASSOCIATION: Arthur D. Little, Inc.

EXPERIENCE: $\quad 16$ Years

- $\quad$ Arthur D. Little, Inc.

- Quality Assurance Specialist for the Tiger Team assessments of the Strategic Petroleum Reserves, Los Alamos National Laboratory, Sandia National Laboratory, Albuquerque, and Fermi National Accelerator Laboratory; Quality Assurance Specialist for the environmental audit of the West Valley Demonstration Project and the progress assessment at the Rocky Flats plant; and Management Systems Specialist for the routine environmental audit of the Hanford Site and the environmental management assessment of the Lawrence Livermore National Laboratory.

- Quality Assurance Manager for a U.S. Department of Energy program through Westinghouse Savannah River Company. Responsible for implementing a manufacturing/quality program that received certification from the American Society of Mechanical Engineers.

- Quality Assurance Manager for a major project for the U.S. Army. Responsible for oversight of the design, fabrication, testing, and delivery of several prototype air-monitoring laboratories and shelters. This project required the generation of the Quality Assurance Program Plan covering all phases of the project. The program encompassed both testing and inspection.

- Served the U.S. Air Force Prototype Flight Cryocooler (PFC) program office as Quality Assurance Manager; revised the quality assurance manual to update and improve Arthur D. Little, Inc., quality practices, primarily in the area of quality systems; implemented a failure analysis and corrective action system and initiated audits and reviews of all the quality and manufacturing operations.

ĖDUCATION: $\quad$ M.B.A., Business Administration, New Hampshire College

B.S., Biology, Boston College 
NAME: $\quad$ Raeann Reid

AREA OF RESP: Program Evaluation, Reporting and Corrective Action; Internal and External Communication

ASSOCIATION: Arthur D. Little, Inc.

EXPERIENCE: $\quad 22$ Years

- $\quad$ Arthur D. Little, Inc.

- Team Coordinator for Tiger Team assessments of the Energy Technology Engineering Center, the Naval Petroleum Reserves in California, the Strategic Petroleum Reserves, and the Naval Petroleum and Oil Shale Reserves in Colorado, Utah, and Wyoming; for the environmental management assessment of the Waste Isolation Pilot Plant; and for routine environmental audits of Argonne National Laboratory-West, the Pinellas Plant, and the Hanford Site.

- Deputy Team Coordinator for the Tiger Team assessment of Idaho National Engineering Laboratory and the environmental management assessment of the Fernald Environmental Management Project.

- Technical Specialist evaluating toxic and chemical materials management for the Tiger Team assessment of Energy Technology Engineering Center; and Management Specialist for the environmental management assessment of the Superconducting Super Collider.

- Led and participated in audits and risk assessments for several Arthur D. Little clients, primarily in the petrochemical and refining industries, including chemical manufacturing plants, chemical and oil terminals, oil refineries, and oil and gas production facilities.

- $\quad$ Other Industry Experience

- Experience in environmental operations; environmental regulatory affairs; industrial and commercial hazardous waste management, site evaluation, remediation, and offsite disposal; and industrial and commercial laboratory management.

- While working for a major petrochemical manufacturer, audited toll manufacturers, bulk terminals, repackaging plants, recyclers, and commercial disposal facilities.

EDUCATION: $\quad$ B.S., Mathematics, Minor Chemistry, Texas Technological University 
NAME: $\quad$ Vee Richardson

AREA OF RESP: Administrator

ASSOCIATION: Development Technologies, Inc.

EXPERIENCE: $\quad 28$ YearS

- Development Technologies, Inc.

- Administrative Team Coordinator providing support to the Department of Energy, Office of Environmental Audit, in conducting environmental assessments of DOE sites. Participated as Administrator for the routine environmental audits of Sandia National Laboratories, California, and the Hanford Site, and for the baseline environmental audit of the Nevada Test Sites Offsite Areas.

- Provided administrative and technical support to an interdepartmental, 27-agency task force and five of its working groups to update the National Response Plan. The Plan defines the Federal government's response to natural and manmade disasters.

- Consultant

- Coordinated Inaugural Prayer Service honoring President-elect Bill Clinton, and was responsible for logistical arrangements; coordination with Presidential Inaugural Committee, Secret Service, and religious leaders; recruiting and briefing volunteers; and supervising onsite activities.

- Wrote information materials for national convocation attended by more than 2,000 people.

- Served as Deputy to the Managing Director of Administration for the Desert Storm National Victory Celebration; coordinated and supervised set-up of headquarters operation, making facilities for more than 125 staff and volunteers fully operational within one week; designed and managed computer system; scheduled transportation systems; and supervised staff.

- The Ability Group

- Owned and managed business services bureau; managed projects, hired and trained support staff and contractors, marketed and maintained working relationships with clients.

- Other Experience

- $\quad 15$ years in administrative management with law firms, staff assistant at Department of State, member of trial team during U.S. V. AT\&T, and highlevel secretarial positions.

EDUCATION: Oklahoma Baptist University 
APPENDIX B

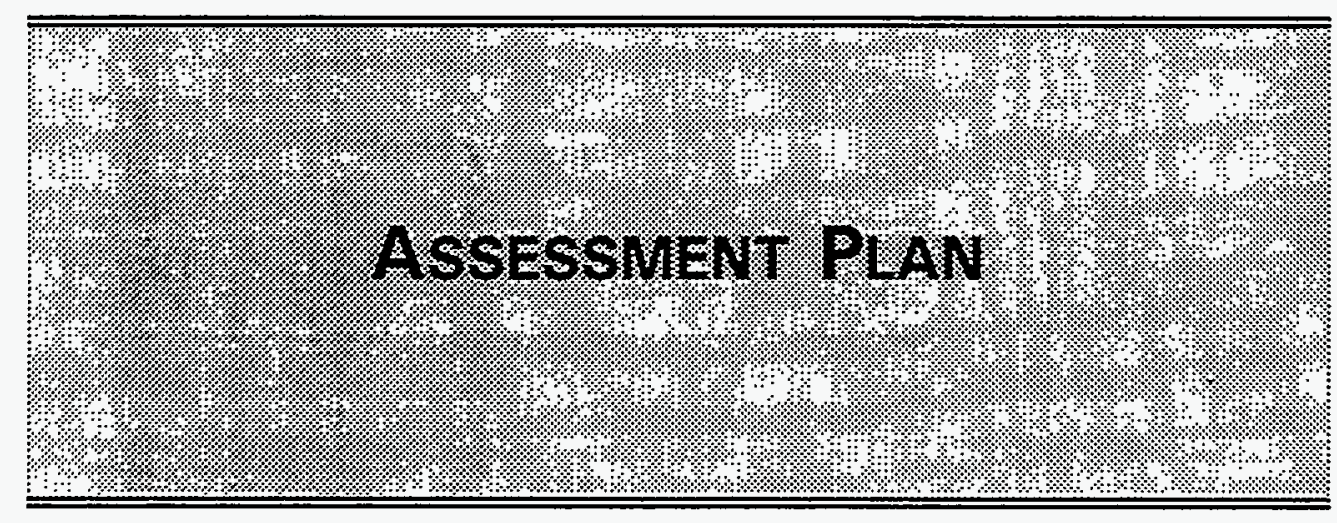


Page intentionally blank 


\section{Assessment Plan}

for the DOE Environmental Management Assessment of the National Institute for Petroleum and Energy Research

August 15-26, 1994 
Table of Contents

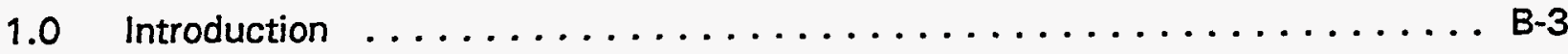

2.0 Environmental Assessment Implementation $\ldots \ldots \ldots \ldots \ldots \ldots \ldots$ B-5

2.1 Pre-Assessment Activities $\ldots \ldots \ldots \ldots \ldots \ldots \ldots \ldots \ldots \ldots \ldots$ B-5

2.2 On-site Activities and Reports $\ldots \ldots \ldots \ldots \ldots \ldots \ldots \ldots \ldots$ B-5

2.3 Post-Site Activities . . . . . . . . . . . . . . . . . B-6

3.0 Organizational Structure $\ldots \ldots \ldots \ldots \ldots \ldots \ldots \ldots \ldots \ldots \ldots \ldots \ldots \ldots \ldots$ B-7

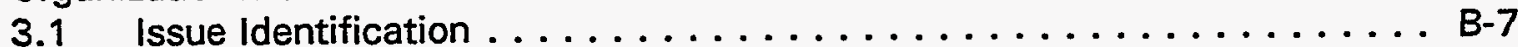

3.2 Records Required ...................... B-8

4.0 Environmental Commitment . . . . . . . . . . . . . . . . . B-9

4.1 Issue Identification $\ldots \ldots \ldots \ldots \ldots \ldots \ldots \ldots \ldots \ldots \ldots \ldots$ B-9

4.2 Records Required $\ldots \ldots \ldots \ldots \ldots \ldots \ldots \ldots \ldots \ldots \ldots$ B-9

5.0 Environmental Protection Programs . ................. B-11

5.1 Issue Identification . . . . . . . . . . . . . . . . . .

5.2 Records Required $\ldots \ldots \ldots \ldots \ldots \ldots \ldots \ldots \ldots \ldots \ldots \ldots \ldots \ldots, 12$

6.0 Formality of Environmental Programs $\ldots \ldots \ldots \ldots \ldots \ldots \ldots \ldots$ B-13

6.1 Issue Identification . . . . . . . . . . . . . . . . B-13

6.2 Records Required $\ldots \ldots \ldots \ldots \ldots \ldots \ldots \ldots \ldots \ldots \ldots \ldots \ldots \ldots$

7.0 Internal and External Communication $\ldots \ldots \ldots \ldots \ldots \ldots \ldots$ B-15

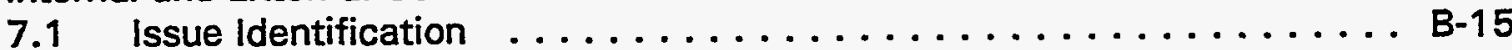

7.2 Records Required $\ldots \ldots \ldots \ldots \ldots \ldots \ldots \ldots \ldots \ldots \ldots \ldots \ldots$

8.0 Staff Resources, Training and Development ............... B-17

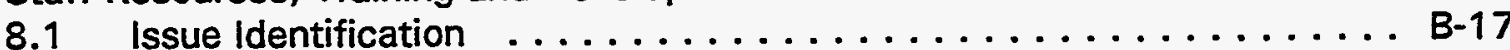

8.2 Records Required $\ldots \ldots \ldots \ldots \ldots \ldots \ldots \ldots \ldots \ldots \ldots$ B-18

9.0 Program Evaluation, Reporting, and Corrective Action .......... B-19

9.1 Issue Identification $\ldots \ldots \ldots \ldots \ldots \ldots \ldots \ldots \ldots \ldots \ldots \ldots$ B-19

9.2 Records Required $\ldots \ldots \ldots \ldots \ldots \ldots \ldots \ldots \ldots \ldots \ldots$ B-19

10.0 Environmental Planning and Risk Management $\ldots \ldots \ldots \ldots \ldots \ldots \ldots$ B-21

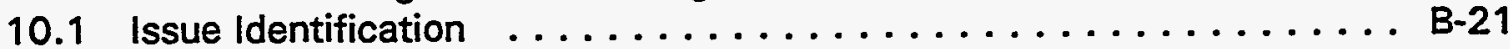

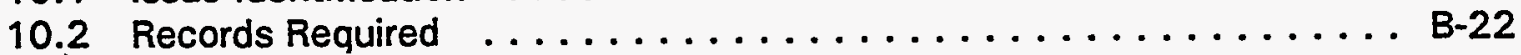

11.0 Quality Assurance $\ldots \ldots \ldots \ldots \ldots \ldots \ldots \ldots \ldots \ldots \ldots \ldots \ldots$ B-23

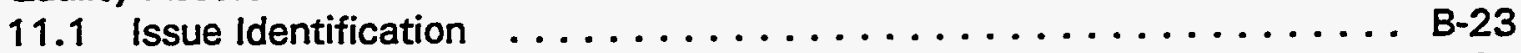

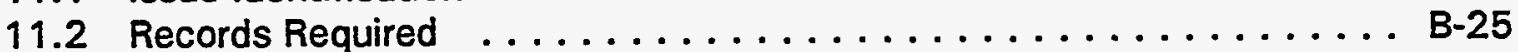

Attachment A Schedule of Onsite Activities (Not attached) 


\subsection{Introduction}

The DOE Environmental Audit Program is carried out by the Office of Environmental Audit $(E H-24)$ within the Office of Environment, Safety and Health (EH). The program was created in 1985 with a goal to provide a continuing program of internal, independent oversight of line management's environmental performance, in support of DOE's broader goal of achieving full compliance and excellence in the environmental area. The objectives of the program in achieving this goal include:

- Conducting environmental management assessments within line programs;

- Conducting a continuing program of field/technical environmental audits of major and other DOE facilities;

- $\quad$ Conducting special issue assessments to assess high priority issues at a particular site, or which cut across site and program lines; and

- Supporting line management self-assessment programs through continuing updates and automation of audit protocols, training, and other mechanisms of transferring the special auditing expertise of EH-24 to the field.

The assessment of the National Institute for Petroleum and Energy Research (NIPER) during the period of August 15-26, 1994, will be an Environmental Management Assessment. It will evaluate the effectiveness of environmental management programs established by the DOE Bartlesville Project Office (BPO) and their support contractor BDM Oklahoma (BDM). The assessments are conducted in accordance with the DOE Environmental Audit Program Guidance, Protocol for Conducting Environmental Management Assessments of DOE Organizations (DOE/EH-0326), and Performance Objectives and Criteria for Conducting DOE Environmental Audits (DOE/EH-0358).

From an organizational perspective, the scope of the assessment will also include environmental management issues at the Headquarters Office of Fossil Energy (FE) and the Pittsburgh Energy Technology Center (PETC) as they impact the environmental operations at NIPER. The assessment team will focus on line management's performance in developing and implementing environmental programs, consistent with DOE expectations for environmental excellence.

From a functional perspective, the scope of the NIPER Assessment is comprehensive in that it covers a full range of relevant management systems. This includes:

- $\quad$ Organizational Structure;

- Environmental Commitment;

- Environmental Protection Programs;

- Formality of Environmental Programs;

- Internal and External Communication; 
- Staff Resources, Training, and Development;

- Program Evaluation, Reporting, and Corrective Action;

- Environmental Planning and Risk Management; and

- Quality Assurance (QA).

Issues related to implementation of corrective actions, groundwater monitoring, air and surface water programs, and tailings remediation will receive special attention

The information in this Environmental Management Assessment plan is based on information received by the Assessment Team as of the end of the day on July 21, 1994 . 


\subsection{Environmental Assessment Implementation}

The NIPER Environmental Management Assessment will be conducted by a team consisting of a Team Leader from the Office of Environmental Audit (EH-24) and a Group Coordinator and five management systems specialists from Arthur D. Little, Inc. (ADL). The names and assignments are listed below:

$\begin{array}{lll}\begin{array}{l}\text { Joe Delaney } \\ \text { Rana Gupta }\end{array} & \text { ADL } & \text { Group Coordinator } \\ \text { Ed Maher } & \text { ADL } & \text { Environmental Commitment; Organizational Structure } \\ \text { ADL } & \begin{array}{l}\text { Environmental Planning and Risk Management; Staff } \\ \text { Resources, Training, and Development }\end{array} \\ \text { Raeann Reid } & \text { ADL } & \begin{array}{l}\text { Internal and External Communications; Program } \\ \text { Evaluation, Reporting and Corrective Action }\end{array} \\ \text { Scot Gnewuch } & \text { ADL Environmental Protection Programs; Formality of }\end{array}$

\subsection{Pre-Assessment Activities}

Pre-assessment activities for the NIPER Environmental Management Assessment included the issuance of an introduction and information request memorandum, a site visit, and initial review of documentation which was sent to the assessment team by NIPER as a result of the information request memorandum.

The pre-site visit was conducted on June 29-30, 1994 by the DOE Team Leader and the Team Coordinator from Arthur D. Little. The purpose of the visit was to brief site personnel on the purpose and scope of the Environmental Management Assessment, to become familiar with NIPER and its operations, to review information being supplied by NIPER and request additional information, and to coordinate activities for the upcoming assessment.

\subsection{On-site Activities and Reports}

The on-site activities for the Environmental Management Assessment will begin August 15 and continue through August 26, 1994. On-site activities will include file/record reviews and interviews with NIPER management and staff (Note: the term NIPER includes both BPO and BDM personnel).

The agenda for the assessment (including a preliminary interview schedule) is shown in Attachment A. The interview schedule reflects the assessment team's best attempt to identify relevant personnel to be interviewed. Based on past experience, these schedules will change as additional information is gathered by the assessment team members and 
based on availability of site personnel. Modifications to the interview schedule, or other elements of the agenda, will be coordinated with the designated NIPER contacts.

During the assessment, the team will conduct daily debriefing sessions with NIPER management to review progress and concerns to date. A factual accuracy review of all findings will begin in the middle of the second week of the assessment. A closeout briefing will be conducted at the conclusion of the onsite portion of the assessment. A summary of the results of the assessment, including key findings, will be presented by the assessment team leader at that time. Also at the closeout, a draft assessment report will be provided to NIPER for review and comment.

\subsection{Post-Site Activities}

Following the on-site activities NIPER will have the opportunity to submit final comments on the draft assessment report. After reviewing these comments, EH-24 will issue a final report. NIPER will be responsible for preparing an action plan which will be reviewed by $\mathrm{EH}-24$. The following is a tentative schedule for completion of these post-site activities.

September 9 September 30 October 7 October 21 November 21
Site and FE comments on draft report due Final assessment report issued by $\mathrm{EH}-1$ Draft action plan due (six weeks after closeout) EH-24 comments on draft action plan Final action plan due through FE-1 to $\mathrm{EH}-1$ 


\subsection{Organizational Structure}

\subsection{Issue Identification}

The Environmental Management Assessment activities for Performance Objectives and Criteria (POC) EM.1, Organizational Structure, will assess whether NIPER's organizational structure ensures environmental protection, compliance, and excellence. In particular, the assessment will be designed to consider whether the environmental management organization structure has clear lines of authority, well-defined roles and responsibilities, and sufficient organizational structure. Organizational structures of BPO and BDM will be reviewed. Areas of particular interest will include:

- The clarity with which the organizational structure is delineated and communicated to NIPER staff;

- $\quad$ Organizational placement of environmental staff at both BPO and BDM;

- The environmental management structures of BPO and BDM and their relationship with one another;

- The degree to which actual lines of environmental management authority and responsibility are consistent with formal documents that define organizational roles, responsibilities and authority;

- The organizational roles and responsibilities with respect to oversight of off-site activities (e.g., Metairie Site Office);

- The definition and understanding of functional relationships between environmental support groups and line units;

- The existence of management systems and procedures to promote responsibility and maintain accountability; and

- $\quad$ The organizational relationships between FE, PETC and NIPER as they relate to environmental oversight, support, and reporting.

The general approach to the assessment will include a review of documentation regarding organizational structure, and interviews with NIPER management and staff. Coordination with other assessment team members will be routine and extensive. Special attention will be paid to coordination with Environmental Commitment (EM.2), Environmental Protection Programs (EM.3) and Internal Communications (EM.5). 


\subsection{Records Required}

The assessment will include review of key documents relating to organizational structure including:

- $\quad$ Latest organization charts for each organization (BPO, BDM, PETC and FE);

- Organizational chart showing relationship among organizations;

- Charters;

- DOE directives, memoranda of understanding, etc.;

- Job descriptions and performance criteria for key management and operating personnel;

- $\quad$ Performance reviews of selected staff; and

- Environmental Program Implementation Plan (EPIP). 


\subsection{Issue Identification}

The Environmental Management Assessment activities for POC EM.2, "Environmental Commitment," will review and evaluate the organization's commitment to achieving environmental excellence. The assessment team will evaluate whether NIPER demonstrates a positive attitude and proactive approach to environmental management. Areas of particular interest will include:

- The existence and distribution of a formal statement of policy that places priority on environment, safety, and health, and that delineates NIPER's environmental goals, and how they are to be met;

- Evidence in interviews of a general understanding and acceptance of the importance of environmental protection, and a sense of "ownership" of environmental protection;

- Top management encouragement of input or concerns from employees on environmental issues;

- Long term planning set forth by BPO and BDM to address environmental concerns related to NIPER;

- $\quad$ Resources (human and financial) allocated to NIPER's environmental program;

- NIPER's commitment to appropriate placement of environmental staff; and

- FE's and PETC's level and nature of environmental commitment to NIPER.

The general approach to the assessment will include a review of documentation related to environmental management and interviews with management and line operation staff from BPO, BDM, PETC and FE.

\subsection{Records Required}

The assessment will include review of key documents relating to environmental commitment at NIPER including:

- Formal statement of environmental management policy;

- Additional, issue-specific policies addressing more focused environmental concerns;

- Senior management statement of support for environmental management efforts that are included in an annual report, speeches, internal newsletters, and other documents; 
- Accounts of employee or organization involvement in, or work with, environmental task forces, environmental professional associations, or local community organizations;

- BDM Management Plan; and

- Environmental Program Implementation Plan. 


\subsection{Environmental Protection Programs}

\subsection{Issue Identification}

The Environmental Management Assessment activities for POC EM.3, Environmental Protection Programs, will evaluate whether NIPER has the programs in place to ensure compliance with Federal, state, and local regulations as well as DOE orders. Because of the recent management transition from IITRI to BDM, it is understood that many of the programs required by DOE Orders are in their infancy. Therefore, the emphasis of the review will be on determining whether effective and comprehensive programs are being developed, rather than fully implemented. The primary issue will be to ensure that the planned environmental protection programs will conform with performance objectives and prescriptive requirements of applicable DOE Orders and other environmental requirements. Issues of specific concern include:

- Effectiveness of environmental planning and risk management associated with corrective actions, groundwater monitoring, surface water and air programs, and tailings cleanup;

- The environmental management interface between BPO and BDM Oklahoma;

- Air emissions source identification, control, and monitoring;

- Surface water protection including source identification, spill prevention and control, and reporting;

- $\quad$ Potable water supply protection including backflow prevention systems;

- Groundwater protection programs including monitoring;

- Management and control of toxic and chemical materials;

- Management of solid, hazardous and radioactive waste including source identification, characterization, training, minimization, contingency planning, record keeping, and treatment, storage and disposal practices; and

- Underground storage tank management systems.

The assessment will be conducted primarily by interviewing personnel from BPO and BDM Oklahoma. The personnel will include those people responsible for environmental activities. However, some non-environmental personnel may be interviewed to evaluate the effectiveness of some programs, essentially determining if environmental programs are reaching people not directly related to their development. Prior to arriving onsite, and during the assessment, reviews will be performed of documentation supporting those programs, or demonstrating their proper implementation. Limited field investigations may also be conducted to verify the planning and implementation of environmental protection programs and procedures. Communication will be maintained with personnel conducting assessments of other environmental activities to assure all cross cutting issues are addressed. 


\subsection{Records Required}

The following types of documents will be reviewed if available:

- Environmental program plans required by DOE 5400.1;

- Source and emission inventories for air and water pollution control;

- Toxic and chemical materials management plan;

- Emergency response and remedial action plan;

- Environmental incident reporting procedures;

- $\quad$ Preventative maintenance and inspection procedures; and

- $\quad$ BDM Management Plan.

- Tiger Team Assessment Action Plan 


\subsection{Formality of Environmental Programs}

\subsection{Issue Identification}

The Environmental Management Assessment activities for POC EM.4, Formality of Environmental Programs, will evaluate whether NIPER conducts environmental protection activities in accordance with formal programs supported by controlled documentation. The assessment will specifically evaluate:

- The current methods of tracking and interpreting regulations and DOE orders, and how they are incorporated into policies, standards, guidance documents and procedures;

- The process of creating, approving and implementing new procedures at NIPER, and the effectiveness of a graded approach to the implementation of DOE orders;

- Methods of conducting inspections and maintaining records of those inspections to assure facility environmental compliance. The emphasis will be placed on environmental compliance, not safety and health issues;

- The formality of managing offsite environmental oversight activities such as the Metairie Site, and offshore drilling activities;

- The formal management interface between BPO and BDM Oklahoma as it relates to environmental oversight;

- Systems for maintaining and retaining records, and for assuring timely completion of regulatory and management reporting requirements;

- Systems to distribute regulatory information, procedures, and guidance to all relevant personnel and operational groups within DOE and contractor organizations;

- $\quad$ Oversight procedures and systems, including programs for routine site inspections and compliance checks; and

- Systems to identify, report, investigate, and track trends and to correct identified environmental problems.

The assessment will be conducted primarily by interviewing personnel from BPO and BDM Oklahoma. The personnel will include those people responsible for environmental activities. Prior to arriving onsite, and during the assessment, reviews will be performed of available documentation. Communication will be maintained with personnel conducting assessments of other environmental activities to assure all cross cutting issues are addressed.

\subsection{Records Required}

Documents will be reviewed prior to, and during the site visit. The following types of documents will be reviewed: 
- Program specific and general ES\&H policies, procedures, and guidance manuals;

- Environmental protection and management plans and procedures;

- $\quad$ Standard site operating procedures;

- Inspection checklists, logs, and procedures;

- Environmental incident and occurrence reports (emphasis will be placed on environmental reports, not health and safety reports);

- Environmental Program Implementation Plan;

- Environmental Monitoring Plan;

- $\quad$ BDM Oklahoma Management Plan; and

- Waste Minimization and Pollution Prevention Awareness Plan. 


\subsection{Internal and External Communication}

\subsection{Issue Identification}

The Environmental Management Assessment activities for POC EM.5, Internal and External Communication, will be designed to determine whether formal and informal channels of communication are effectively used to emphasize management commitment to environmental protection; to promote awareness and support of environmental policies and programs throughout the organization; and to share information with external organizations, such as regulatory agencies, environmental groups, and the community. The review will focus on the modes of communication used and their effectiveness. Key issues that will be addressed include the following:

\section{Internal Communication}

- Extent, effectiveness, and timeliness of NIPER's communication of environmental policies, standards, performance and responsibilities to employees;

- Environmental management communications between BPO and BDM;

- Communication between environmental quality assurance functions at both the BPO and BDM levels;

- Mechanisms for "bottom-up" communications of environmental concerns through traditional reporting channels and through anonymous systems;

- Clarity and timeliness of directives and guidance that communicate environmental policies and guidelines to all personnel; and

- Employee awareness of personal environmental responsibilities and management systems to promote that awareness.

\section{External Communications}

- Working relationships with FE and PETC relating to oversight activities;

- Formal communication of environmental risks and protection efforts to external organizations;

- Provision for external parties to be involved in key decisions related to environmental protection;

- Responsiveness to environmental concerns expressed by external parties; and

- External recognition of NIPER's commitment to environmental protection.

The general approach to the assessment will include interviews with NIPER personnel responsible for environmental policy and program communication, as well as affected personnel (management and staff). As appropriate, interviews will also be conducted with selected external parties (State of Oklahoma regulatory agencies). The assessment will 
also include a review of documentation supporting internal and external communication programs.

\subsection{Records Required}

The assessment will include review of key documents relating to communication including:

- Samples of the scope of relevant management reports and staff meeting minutes;

- Forms and guidelines for internal anonymous reporting of environmental issues;

- Guidance documents for interpretation and implementation of environmental regulations and policies;

- $\quad$ NIPER newsletter(s) that communicate and promote environmental awareness;

- $\quad$ Press releases relating to environmental activities and programs;

- Documentation of information and awareness programs for affected external parties; and

- Other records as determined onsite. 


\subsection{Staff Resources, Training and Development}

\subsection{Issue Identification}

The Environmental Management Assessment for POC EM.6, Staff Resources, Training and Development, will involve a review and analysis of the NIPER operations to verify that staff resources are sufficient to develop and implement environmental protection programs; that all personnel have received environmental protection training commensurate with their job responsibilities; and that professional development opportunities for environmental staff and position grades are equal to those of their peers in non-environmental positions. Specifically, the assessment will verify the following:

- Quantity of staff is sufficient to ensure environmental goals are met.

- Staffing levels today are adequate for achieving the NIPER's environmental performance goals;

- $\quad$ ESH managers are graded similarly to peer line managers;

- $\quad$ There is a system for identifying the NIPER's short-term and long-term staffing requirements; and

- $\quad$ Staffing support for environmental protection positions is provided in a timely and responsive manner (PETC/FE telephone interview).

- Qualifications of staff are sufficient to ensure environmental goals are met.

- The education, training, and experience of the environmental support staff (including contractors) are adequate to effectively conduct their assigned duties;

- $\quad$ Appropriate job qualifications are established and maintained for environmental positions that match their actual work activities; an

- Environmental responsibilities are built into job descriptions and appraisals of key line management and staff positions.

- Measurement of job performance for environmental positions is appropriate.

- Environmental protection factors are included in performance evaluation standards in appropriate weights; and

- Employee Incentives and advancement are available

- Environmental training performed commensurate with staff position.

- Environmental training needs are reviewed and updated periodically;

- $\quad$ Training is documented and trainee input is solicited; and

- Qualifications of trainers and instructors.

- Environmental staff are provided career opportunities and advancement similar to their peers, and are encouraged to develop supervisory and other professional skills.

The general approach to the assessment will include interviews with BPO and BDM personnel regarding staff resources, training and development, as well as a review of relevant and available documentation. A sampling of line managers will be interviewed and a several non-supervisory employees will be spot interviewed to determine effectiveness and quality of environmental training being performed at BPO and BDM. 


\subsection{Records Required}

In addition to documents reviewed prior to the onsite assessment, documents to be examined at the NIPER may include the following:

- Documented requests for environmental staff;

- A sample of resumes for selected environmental staff and other staff with some environmental responsibilities;

- Performance evaluation standards for both environmental and non-environmental personnel;

- Documentation of training courses and attendance records;

- Training history, educational records, and incentive/award histories for a sample of ESH and line managers; and

- Presentation materials for environmental protection training programs. 


\subsection{Program Evaluation, Reporting, and Corrective Action}

\subsection{Issue Identification}

The activities for POC EM.7, Program Evaluation, Reporting and Corrective Action, will assess whether the organization has self-assessment and oversight programs in place to effectively evaluate environmental protection activities, report environmental concerns, implement corrective actions, and progressively improve environmental management activities. Based on the review of pre-assessment information, the following issues will be further evaluated during the assessment:

- Development and effectiveness of BDM and BPO oversight and self-assessment activities;

- The roles that FE and PETC play in providing oversight of the environmental activities at NIPER;

- The NIPER understanding of all required program evaluation mechanisms, including self-assessments and appraisals;

- Scope and approach of self-assessments and appraisals;

- Assignment of responsibilities for self-assessments/appraisals and qualifications/training of those conducting the assessments;

- Distribution of assessment findings and reports to appropriate managers;

- Systems for prioritizing, tracking and ensuring completion of corrective actions; and

- Existence of "lessons learned" initiatives or programs.

The general approach to assessing this management area will include interviews with staff who are responsible for environmental oversight and interviews with line management who are responsible for self-assessment. The assessment team will also review other relevant documentation not previously provided in the pre-assessment documents.

\subsection{Records Required}

in addition to those documents reviewed prior to the assessment, the following documents will be examined at NIPER:

- Description of the programs, procedures, and responsibilities relating to environmental performance evaluation;

- Reports for audits and appraisals conducted by both internal and external organizations;

- $\quad$ Corrective action plans; 
- Documentation of the corrective action tracking system;

- Trending or lessons learned documentation; and

- Documentation of the qualifications/training of staff responsible for conducting environmental oversight activities. 


\subsection{Environmental Planning and Risk Management}

\subsection{Issue Identification}

The Environmental Management Assessment activities for POC EM.8, Environmental Planning and Risk Management, will include evaluating the effectiveness of project-wide environmental planning activities. The scope of the planning portion of the assessment will include environmental activities as well as more standard business planning activities, such as budgeting, priority setting, and allocation of resources. Short and long-term planning will be addressed. In addition to planning, this portion of the assessment will evaluate the adequacy of systems designed to identify environmental hazards and to minimize and control environmental risks. Areas of particular interest will include the following:

\section{Environmental Planning}

- Effectiveness of environmental planning associated with corrective actions, groundwater monitoring, surface water and air programs, and tailings cleanup;

- Technical and financial planning relating to environmental management and integration with overall organizational planning;

- The adequacy of funding for environmental protection activities;

- $\quad$ Relationships between BPO, BDM, PETC and FE regarding environmental planning;"

- The relative priority that environmental issues are given with respect to production in the planning and budgeting process; and

- The adequacy of the facility's planning for their needs in the areas of pollution control technology and related equipment and services for supporting environmental protection activities at NIPER.

\section{Risk Management}

- Systems for formal review of programs and activities which have the potential to represent a risk to the environment including off-site activities such as offshore drilling; and

- $\quad$ Systems for assessing risks to the environment from operations which include assignment of responsibilities to appropriate staff, procedures, specific mechanisms for identifying hazards and associated risks, assessing the acceptability of identified risks, and risk mitigation actions.

The general approach to the assessment will include interviews with FE, BPO, and BDM personnel responsible for environmental planning and risk management, and a review of documentation supporting this area. 


\subsection{Records Required}

The assessment will include review of key documents relating to environmental planning, including:

- Strategic plans, 5-year plan, 5-year waste management plan;

- Budget documents, Activity Data Sheets;

- Capital expenditure documents;

- Minutes of planning meetings;

- Procedures for startup of site activities (maintenance, construction, excavation, experimentation, etc.);

- Work control procedures;

- NEPA documentation;

- Quality assurance plan for risk management; and

- Descriptions of programs and reports with an emphasis on risk management and risk ranking algorithms. 


\subsection{Quality Assurance}

\subsection{Issue Identification}

The Environmental Management Assessment activities for Quality Assurance (QA) will include a review of the implementation and effectiveness of the NIPER QA programs as applied to environmental monitoring, surveillance and protection programs. This portion of the assessment will evaluate the OA programs both as an element of the environmental management system, and as a requirement driving the management system. The assessment will examine the following issues:

- Development and implementation status of both BPO and BDM QA Programs;

- The level of guidance provided by BPO in the implementation of the BDM QA Program;

- Identification of the process utilized to implement a "graded approach" to OA;

- How environmental data are collected to ensure appropriateness and defensibility of data;

- The degree to which environmental data are used to promote the cost-effective use of resources;

- How environmental data are integrated into the accomplishment of the site's mission;

- The methods by which total quality management and continuous improvement concepts are incorporated into the OA Program; and

- Definition of roles and responsibilities between BDM QA and ESH.

The general approach to the assessment will include interviews with the Bartlesville Project Office (BPO) and the site contractor (BDM) personnel responsible for development, implementation, management, and oversight of NIPER QA activities. Program documentation, such as QA program and implementation plans, and records, such as implementation status and milestone reports, will be reviewed in order to determine the level of implementation and effectiveness of the QA programs.

In performing the QA review, the QA specialist will be interacting with the specialists focusing on management areas. This will be an active two-way exchange. The $Q A$ specialist may provide from the QA Program evidence to support a more global management strength or weakness. In return, the QA specialist may utilize information found in the management assessment to support strengths and weaknesses in the OA Program. Some areas where interaction is expected are: organizational roles and responsibilities; sitewide acceptance of OA philosophy and management commitment to quality; Document control and records management; oversight, including self-assessment, independent assessment and management review; corrective action tracking, reporting, and lessons learned; and qualification and training of QA personnel. The focus of the QA review will be to evaluate $\mathrm{QA}$ as a program and not as individual requirements. 


\subsection{Records Required}

In addition to documents reviewed prior to the onsite assessment, documents to be examined at NIPER may include the following:

- FE and BPO QA Program implementation guidance;

- BPO QA Program documentation;

- $\quad$ Records of BPO and BDM QA oversight activities; and

- Documentation supporting methodology and actions taken in determining the graded-approach to QA program implementation. 


\section{APPENDIX C}

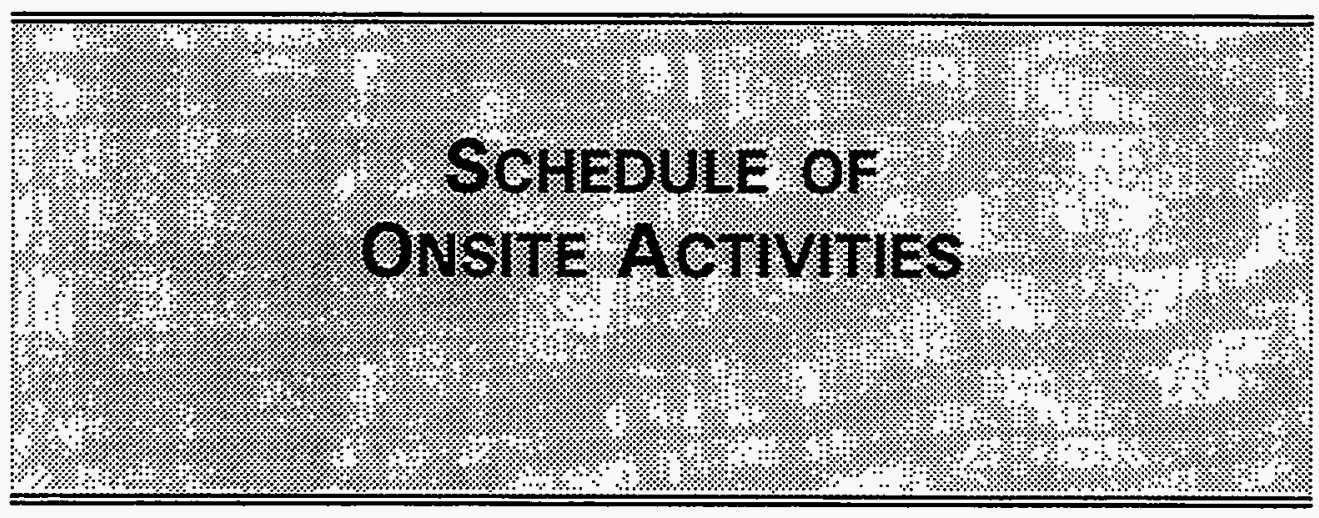


Page intentionally blank 
SCHEDULE OF ONSITE ACTIVITIES

\begin{tabular}{|c|c|c|c|c|c|c|}
\hline 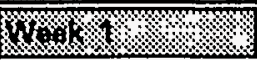 & \% & K & \% w & YhW & \$) & $40+40049$ \\
\hline \begin{tabular}{|l|} 
Rana Gupta \\
a.m. \\
Environmental \\
Commitment \\
Organizational \\
Structure
\end{tabular} & $\begin{array}{l}\text { - Badging } \\
\text { - Orientation } \\
\text { - Safety Briefing }\end{array}$ & $\begin{array}{l}\text { - Daily Debrief } \\
\text { - Interviews } \\
\text { - D. Alleman } \\
\text { - M. Nelson }\end{array}$ & $\begin{array}{l}\text { - Daily Debrief } \\
\text { - Interviews } \\
\text { - T. Wesson } \\
\text { - Operating Staff (R. } \\
\text { Tucker; R. Herard) } \\
\text { - C. Zamuda }\end{array}$ & $\begin{array}{l}\text { - Daily Debrief } \\
\text { - Interviews } \\
\text { - A. Crawley } \\
\text { - D. Alleman } \\
\text { - Followup inter- } \\
\text { views/document } \\
\text { review }\end{array}$ & $\begin{array}{l}\text { - Daily Debrief } \\
\text { - Followup inter- } \\
\text { views/document } \\
\text { reviow } \\
\text { - T. Wesson } \\
\text { - D. Alleman }\end{array}$ & $\begin{array}{l}\text { - Develop findings } \\
\text { and overview }\end{array}$ \\
\hline \multirow[t]{2}{*}{ p.m. } & \multirow{2}{*}{$\begin{array}{l}- \text { Interviews } \\
\text { - B. DiBona } \\
\text { - T. Bukoski } \\
\text { - T. Wesson }\end{array}$} & \multirow{2}{*}{$\begin{array}{l}\text { - Interviews } \\
\text { - K. Robinson } \\
\text { - J. Thompson }\end{array}$} & \multirow{2}{*}{$\begin{array}{l}\text { - Interviews } \\
\text { - T. Wesson } \\
\text { - A. Crawley }\end{array}$} & \multirow[b]{2}{*}{$\begin{array}{l}\text { - Interviews } \\
\text { - N. Comstock } \\
\text { - L. Gillham } \\
\text { - Followup inter- } \\
\text { views/document } \\
\text { review } \\
\text { - Daily report } \\
\text { preparation }\end{array}$} & \multirow{2}{*}{$\begin{array}{l}\text { - Findings develop- } \\
\text { ment } \\
\text { - Interview } \\
\text { - B. DiBone }\end{array}$} & Nhto st 194 \\
\hline & & & & & & $\begin{array}{l}\text { Interviow } \\
\text { - M. Lowe }\end{array}$ \\
\hline \begin{tabular}{|l} 
Scot Gnewuch \\
a.m. \\
Environmental \\
Protection Pro- \\
grams \\
Formality of \\
Environmental \\
Programs
\end{tabular} & - Badging & $\begin{array}{l}\text { - Daily Debrief } \\
\text { - Interviews } \\
\text { - T. Bukoski } \\
\text { - T. Wesson }\end{array}$ & $\begin{array}{l}\text { - Daily Debrief } \\
\text { - Interviews } \\
\text { - M. Ray } \\
\text { - A. Crawley }\end{array}$ & $\begin{array}{l}\text { - Daily Debrief } \\
\text { - Followup inter- } \\
\text { viows/document } \\
\text { review }\end{array}$ & $\begin{array}{l}\text { - Daily Debrief } \\
\text { - Followup inter- } \\
\text { viows/document } \\
\text { review }\end{array}$ & $\begin{array}{l}\text { - Develop findings } \\
\text { and overview }\end{array}$ \\
\hline p.m. & $\begin{array}{l}\text { - Interviews } \\
\text { - D. Alleman } \\
\text { - S. Jones } \\
\text { - Daily report } \\
\text { preparation }\end{array}$ & \begin{tabular}{|} 
Interviews \\
- J. Hughes \\
- B. Folber \\
- Daily report \\
preparation
\end{tabular} & $\begin{array}{l}\text { - Interviews } \\
\text { - J. Ford } \\
\text { - R. Horn } \\
\text { - Daily report } \\
\text { preparation }\end{array}$ & $\begin{array}{l}\text { - Followup inter- } \\
\text { viows/document } \\
\text { reviow } \\
\text { - Daily report } \\
\text { preparation }\end{array}$ & $\begin{array}{l}\text { - Findings develop- } \\
\text { ment } \\
\text { - Daily report } \\
\text { preparation }\end{array}$ & \\
\hline
\end{tabular}




\begin{tabular}{|c|c|c|c|c|c|c|}
\hline & $\begin{array}{c}\text { uo!jesedesd } \\
\text { Loded Nן!eg }\end{array}$ & 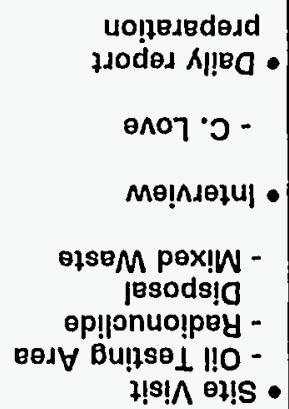 & 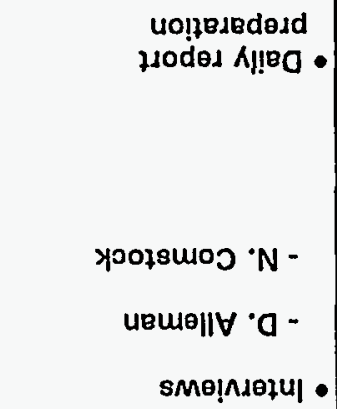 & $\begin{array}{c}\text { uo!̣esedesd } \\
\text { zjodes K!!re }\end{array}$ & $\begin{array}{l}\text { uo!̣esedejd } \\
\text { LJodes K!!ra }\end{array}$ & - w'd \\
\hline 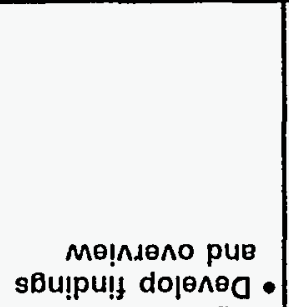 & 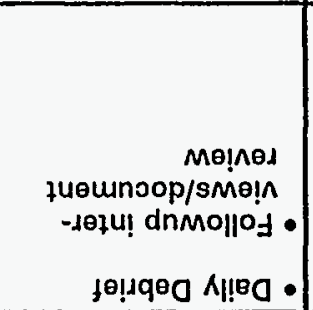 & 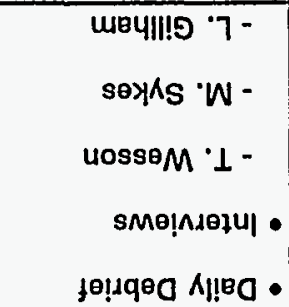 & 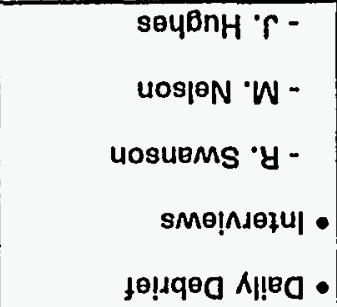 & 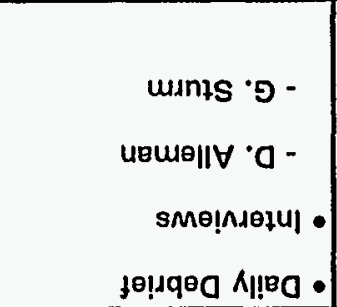 & 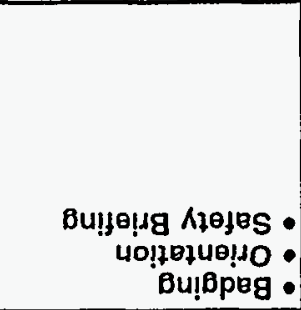 & 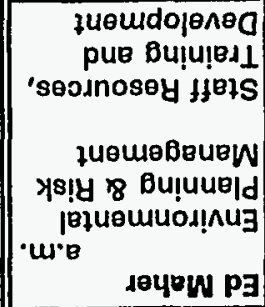 \\
\hline & 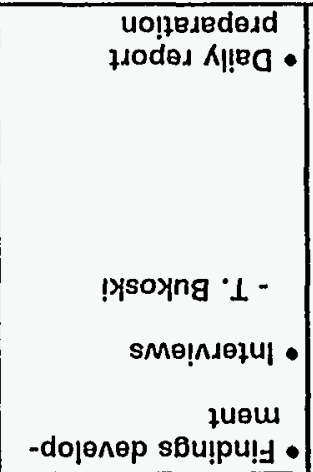 & 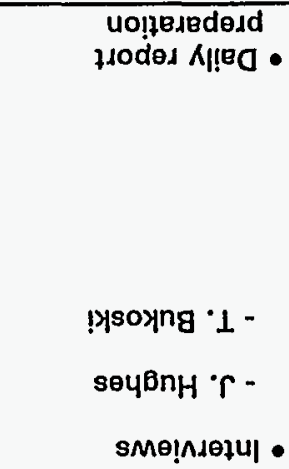 & 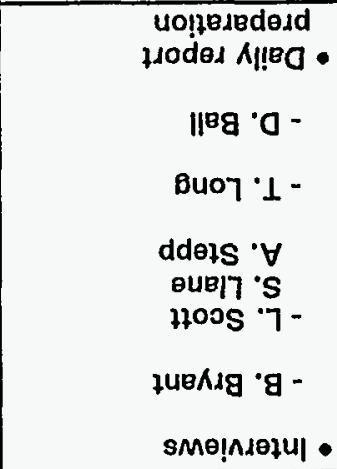 & 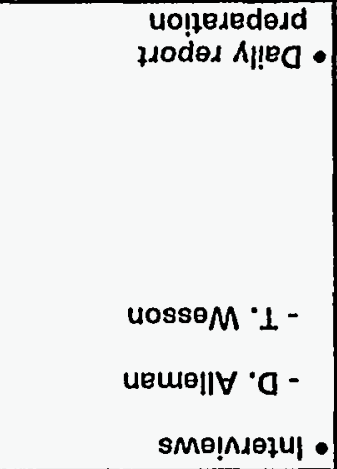 & 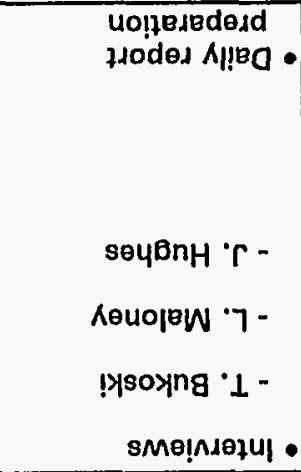 & $\cdot u \cdot d$ \\
\hline $\begin{array}{l}\text { Mө!ndeno puв } \\
\text { sBu!pu!f do|өлөO }\end{array}$ & 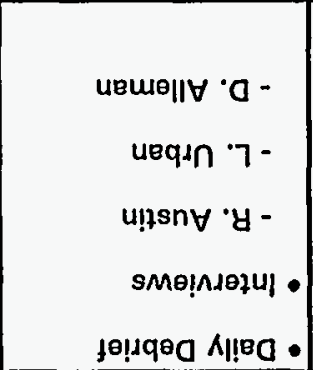 & 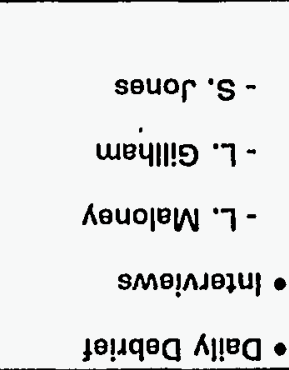 & 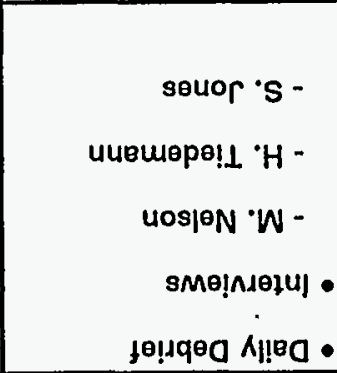 & 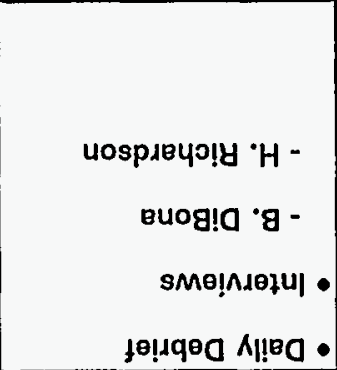 & 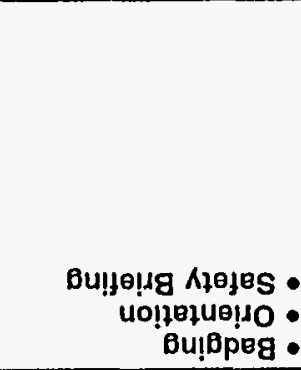 & 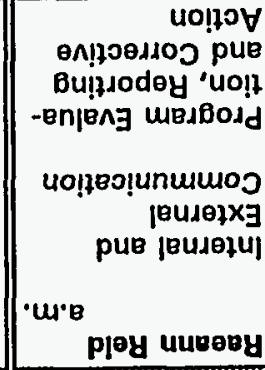 \\
\hline tpotopholos & 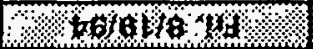 & 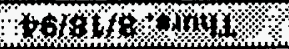 & 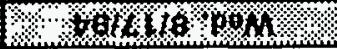 & Yomfg & $\%$ osolos row & \%, $640 \%$ \\
\hline
\end{tabular}


SCHEDULE OF ONSITE ACTIVITIES (continued)

\begin{tabular}{|c|c|c|c|c|c|c|}
\hline$W_{6}(1)$ & \% & 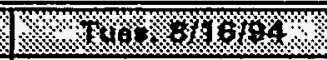 & 1) W & 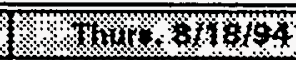 & $1+$ D W $8419 / 94$ & Sor 8120640 \\
\hline \begin{tabular}{|ll} 
Jim Melloni & \\
& a.m. \\
Quality & \\
Assurance & \\
\end{tabular} & $\begin{array}{l}\text { - Badging } \\
\text { - Orientation } \\
\text { - Safety Briefing }\end{array}$ & $\begin{array}{l}\text { - Daily Debrief } \\
\text { - Interviews } \\
\text { - B. DiBona } \\
\text { - T. Bukoski }\end{array}$ & $\begin{array}{l}\text { - Daily Debrief } \\
\text { - Interviews } \\
\text { - T. Wesson } \\
\text { - R. Kay and } \\
\text { M. Stewart }\end{array}$ & $\begin{array}{l}\text { - Daily Debrief } \\
\text { - Interview } \\
\text { - D. Alleman } \\
\text { - H. Richardson } \\
\text { - Followup inter- } \\
\text { views/document } \\
\text { review }\end{array}$ & $\begin{array}{l}\text { - Daily Debrief } \\
\text { - OA Meeting } \\
\text { H. Richardson; } \\
\text { M. Nelson; } \\
\text { R. Kay; } \\
\text { T. Preston } \\
\text { - Followup inter- } \\
\text { views/document } \\
\text { review }\end{array}$ & $\begin{array}{l}\text { - Develop findings } \\
\text { and overview }\end{array}$ \\
\hline
\end{tabular}


SCHEDULE OF ONSITE ACTIVITIES (continued)

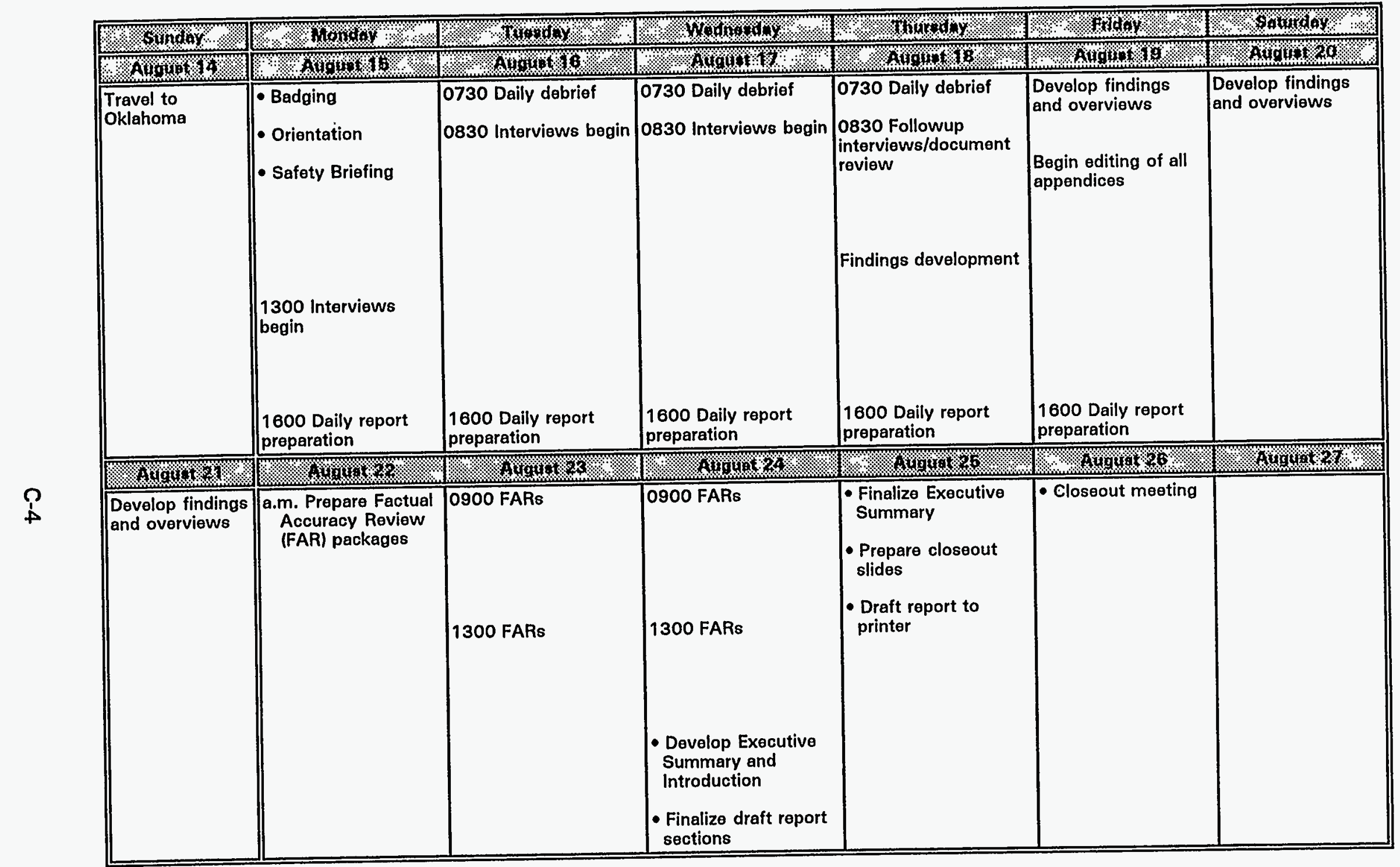




\section{APPENDIX D}

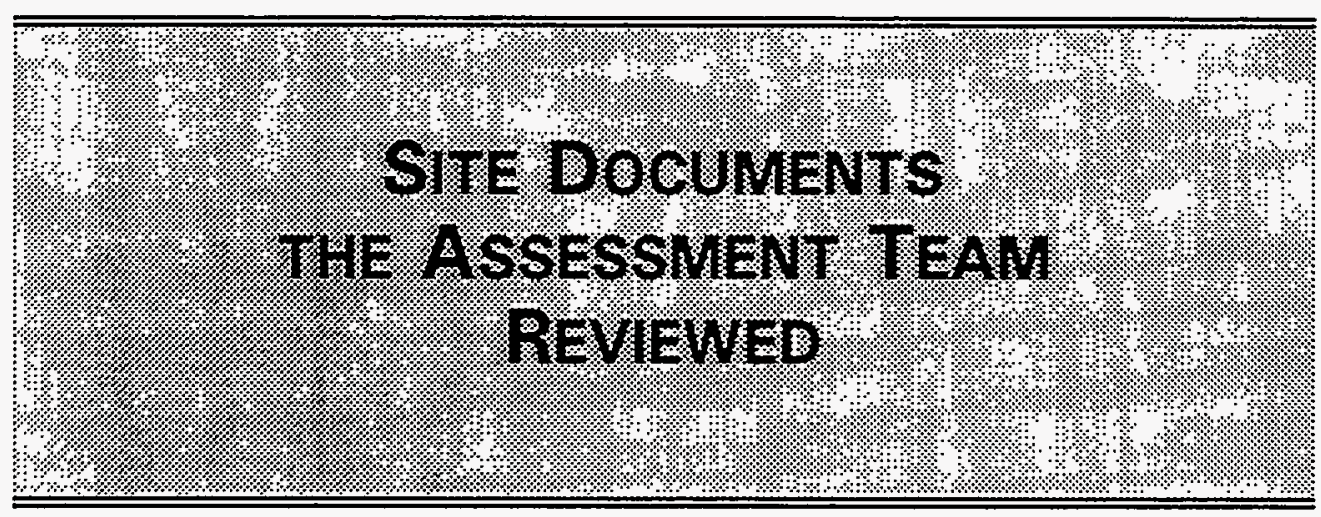


Page intentionally blank

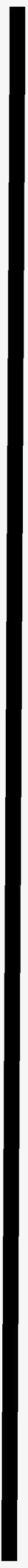


SITE DOCUMENTS THE ASSESSMENT TEAM REVIEWED

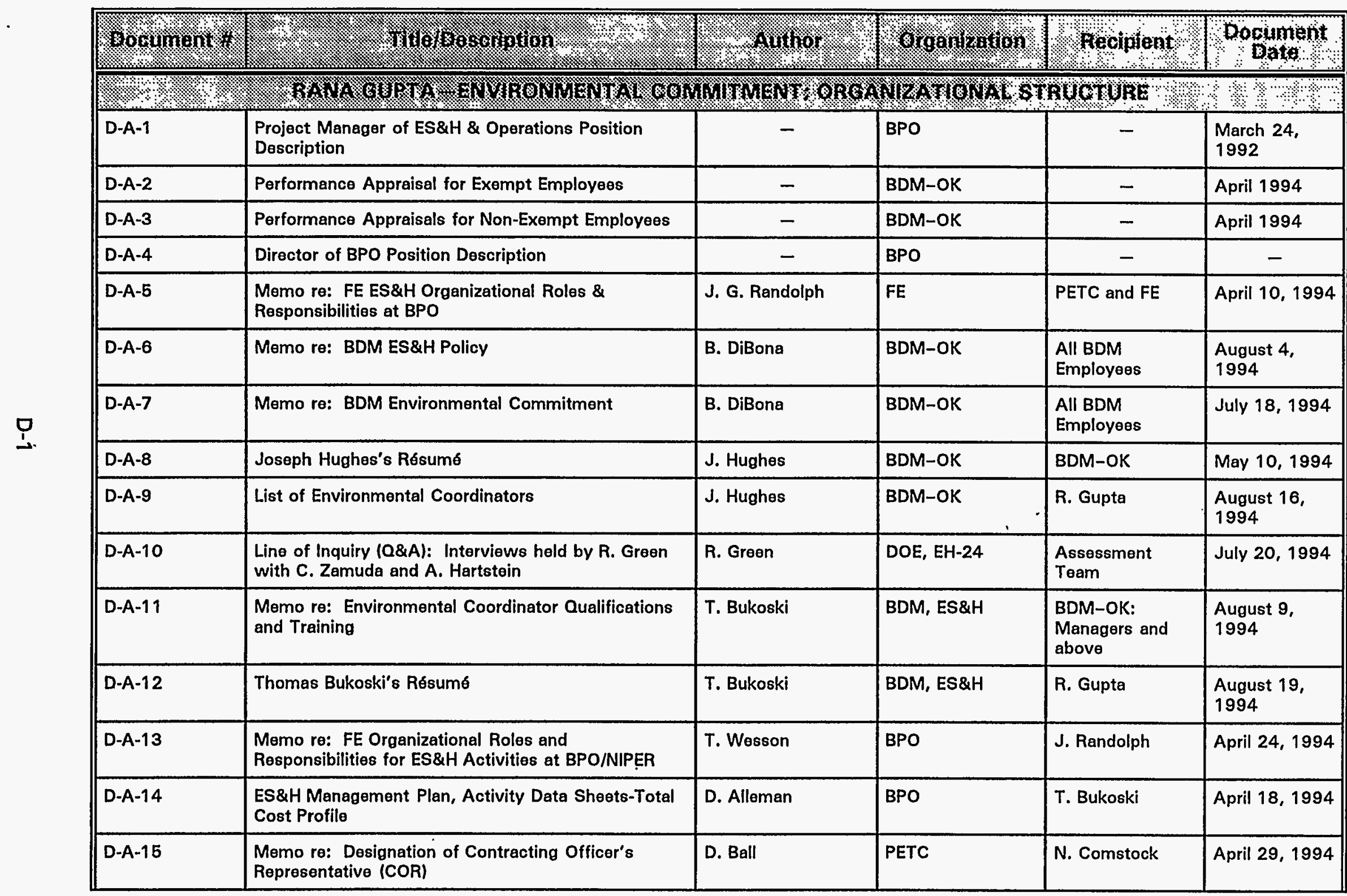


SITE DOCUMENTS THE ASSESSIMENT TEAM REVIEWED (continued)

\begin{tabular}{|c|c|c|c|c|c|}
\hline ooguinomis & L & 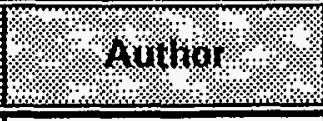 & 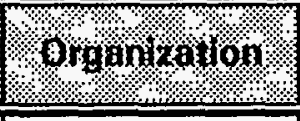 & S.8. Requiegt: & Sognomit. \\
\hline D-A-16 & $\begin{array}{l}\text { Procedures for the Operation of the BDM-OK ES\&H } \\
\text { Committee }\end{array}$ & G. Ste日le & BDM & $\begin{array}{l}\text { All employees: } \\
\text { Managers and } \\
\text { above }\end{array}$ & July 20,1994 \\
\hline D-A-17 & $\begin{array}{l}\text { Memo re: 'Designation of Contracting Officer's } \\
\text { Representative (COR) }\end{array}$ & D. Ball & PETC & D. Alleman & April 22, 1994 \\
\hline D-A-18 & Budget analysis for PETC, METC, and NIPER & A. Crawley & BPO, AEPT & FE-1 & Unknown \\
\hline D-A-19 & $\begin{array}{l}\text { Work Request, Environment, Safety, Health, } \\
\text { Security, and Quality Assurance }\end{array}$ & D. Alleman & BPO, AEPT & PETC ${ }^{\circ}$ & $\begin{array}{l}\text { January } 1 \\
1994\end{array}$ \\
\hline$D-A-20$ & Organizational Charts/Flow Charts & - & - & - & - \\
\hline$D-A-21$ & BPO/NIPER Tiger Team Assessment Plan & - & DOE & - & $\begin{array}{l}\text { December } \\
1992\end{array}$ \\
\hline D-A-22 & $\begin{array}{l}\text { U.S. Department of Energy Office of Environment, } \\
\text { Safoty and Health, Tiger Team Assessment of the } \\
\text { National Institute for Petroleum and Energy Research }\end{array}$ & - & - & - & May 1992 \\
\hline D-A-23 & Bartlesville Project Office Organizational Chart & - & - & - & May 25, 1994 \\
\hline D-A-24 & Letter re: Response to BDM-OK Purchasing Manual & L. Gillham & PETC & B. DiBona & $\begin{array}{l}\text { August 11, } \\
1994\end{array}$ \\
\hline D-A-25 & $\begin{array}{l}\text { Procurement dates for several environmental } \\
\text { contracts }\end{array}$ & M. Lowe & $\begin{array}{l}\text { BDM-OK, } \\
\text { Administration } \\
\text { and Facilities } \\
\text { Dept. }\end{array}$ & R. Gupta & $\begin{array}{l}\text { August 22, } \\
1994\end{array}$ \\
\hline$D-A-26$ & Memo describing BPO's environmental commitment & T. Wesson & BPO & $\begin{array}{l}\text { All BPO and } \\
\text { BDM-OK } \\
\text { employees }\end{array}$ & June 8, 1994 \\
\hline \multicolumn{6}{|c|}{ (1. } \\
\hline D-B-1 & $\begin{array}{l}\text { U.S. Department of Energy Office of Environment, } \\
\text { Safety and Health, Tiger Team Assessment of the } \\
\text { National Institute for Petroleum and Energy Research }\end{array}$ & - & - & - & May 1992 \\
\hline D-B-2 & BPO/NIPER Tiger Team Assessment Plan & - & DOE & - & \begin{tabular}{|l} 
December \\
1992
\end{tabular} \\
\hline
\end{tabular}




\begin{tabular}{|c|c|c|c|c|c|}
\hline $766 \mathrm{l}$ & $\begin{array}{r}\text { Odg } \\
\text { pus yo-wag }\end{array}$ & YGdIN & 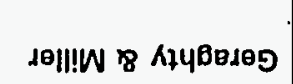 & Al!! & $<L-g-0$ \\
\hline 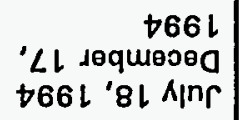 & 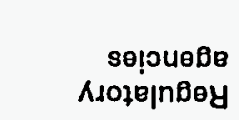 & $\mathbf{H} \exists d \mathbf{N}$ & YO-WOB & 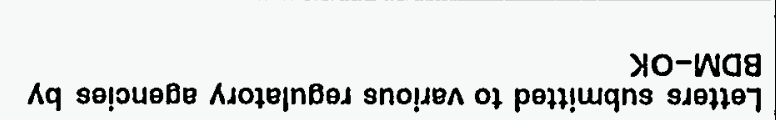 & $9 l-g-a$ \\
\hline t66l ounr & - & YO-wog & - & ue/d uo!pezuemejdu| esuednss $\forall$ Ai!leno wag & $9 l-g-a$ \\
\hline- & - & - & - & 1 101001!Q YO-Wag & $\neg l-g-a$ \\
\hline$D 66\llcorner$ KBW & - & - & - & 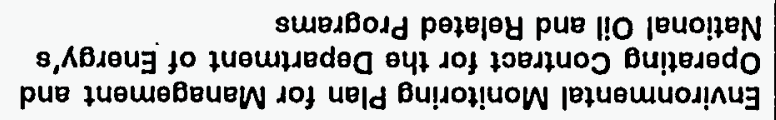 & $\varepsilon l-8-a$ \\
\hline- & - & - & - & 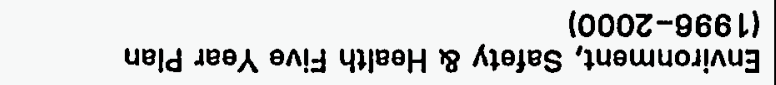 & zl-g-a \\
\hline t66L Adenuer & - & Xo-wag & - & ueld fuomeBruew wag & $11-8-a$ \\
\hline $766 \mathrm{~L}$ YOLEW & - & YO-wag & - & 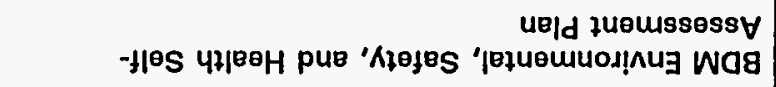 & $0 l-8-a$ \\
\hline $\begin{array}{r}\varepsilon 66 \downarrow \\
' \varepsilon z \text { sөqueseg }\end{array}$ & - & Yo-was & 一 & 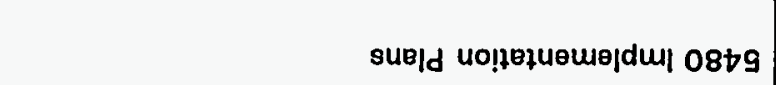 & $6-8-a$ \\
\hline- & - & - & - & 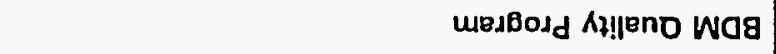 & $8-8-0$ \\
\hline 7661 N Nendq日9 & - & Yo-was & - & uE/d mesBodd өouednss & $<-8-0$ \\
\hline$\nabla 66 \downarrow$ KBW & - & YO-wag & - & 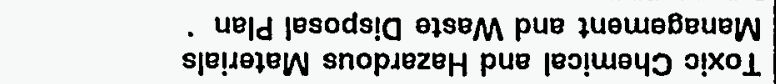 & $9-8-0$ \\
\hline $766\llcorner$ łsnony & YJdIN & Od8 & 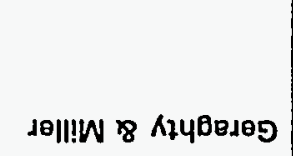 & 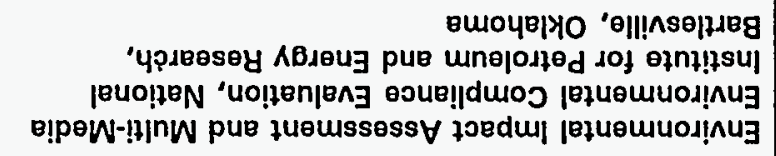 & $9-8-0$ \\
\hline$\nabla 66 \mathrm{~L}$ Anr & - & XO-WO8 & - & 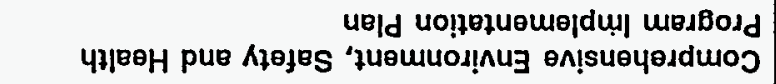 & $t-8-0$ \\
\hline $766 l$ ounr & - & XO-WOA & & 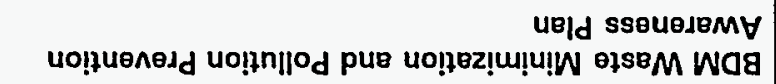 & $\varepsilon-8-0$ \\
\hline
\end{tabular}

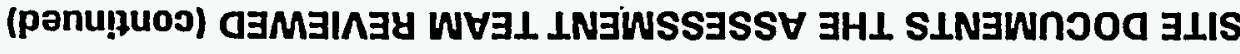




\section{SITE DOCUMENTS THE ASSESSMENT TEAM REVIEWED (continued)}

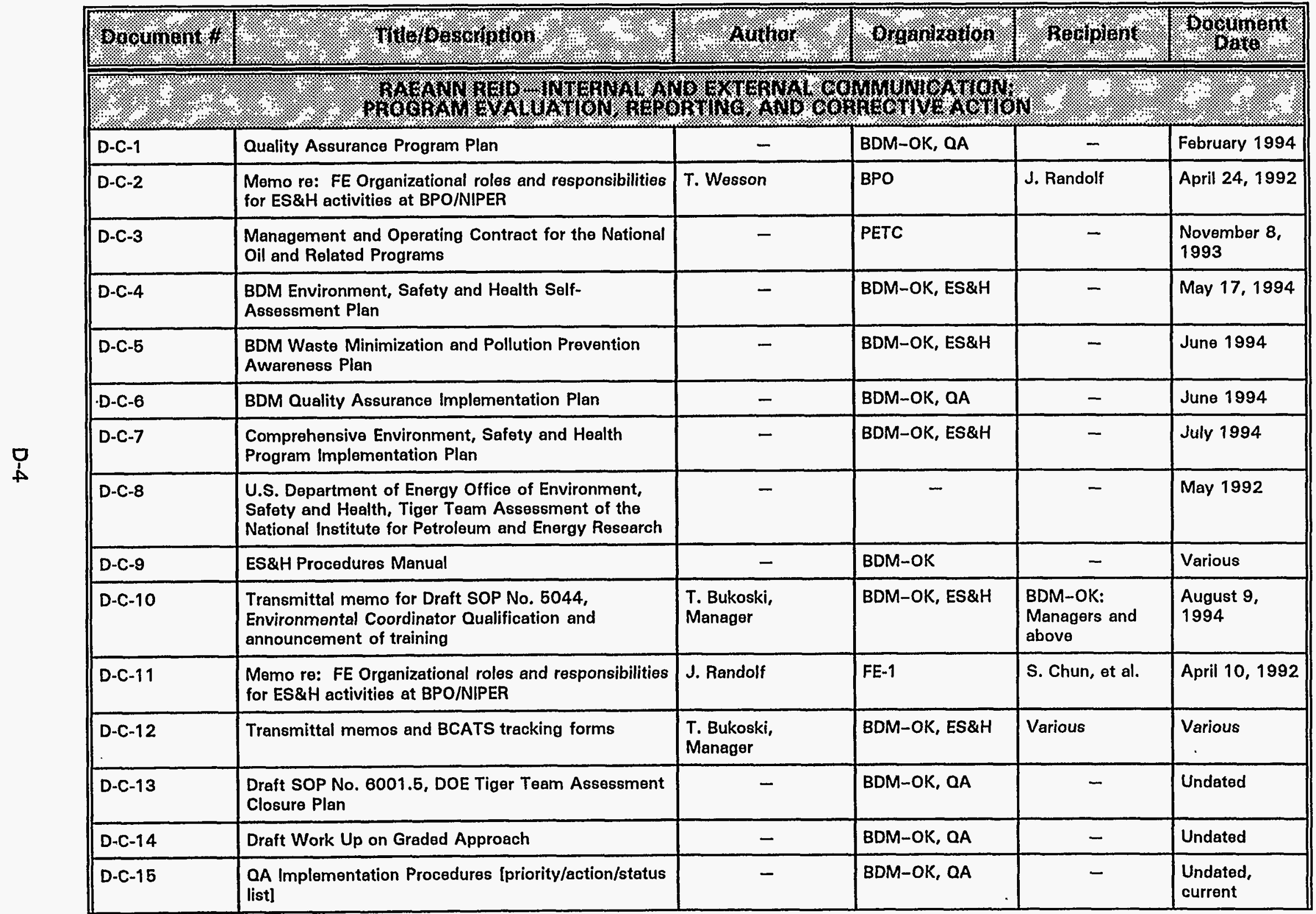




\begin{tabular}{|c|c|c|c|c|c|}
\hline $266 \downarrow$ ' $\theta$ $\| \mu d \forall$ & - & Odg & - & 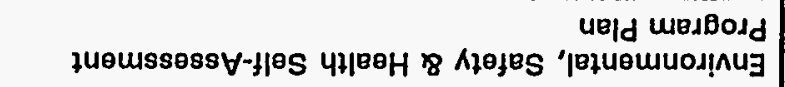 & $6 Z-0-0$ \\
\hline $\begin{array}{r}\varepsilon 66 / \\
' \varepsilon \text { dequeldes }\end{array}$ & - & Odg & uвue\|l ' $\mathbf{O}$ & 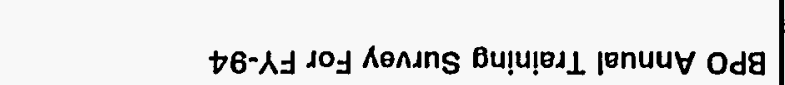 & $8 Z-0-0$ \\
\hline 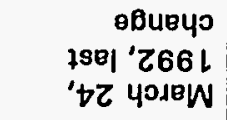 & - & $0.1 \exists d$ & - & 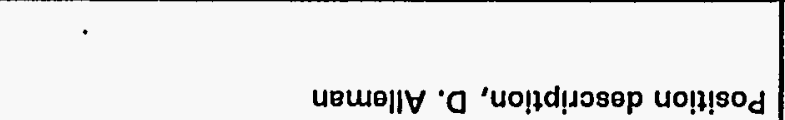 & $\angle Z-O-a$ \\
\hline peippun & $\begin{array}{r}\text { sرoyło pue } \\
\text { jeusnor seg } 81 ! 0\end{array}$ & $\begin{array}{l}\text { zuep!sedd } \theta 47 \text { fo } \\
\text { өอ!H० 'YO-Wag }\end{array}$ & - & 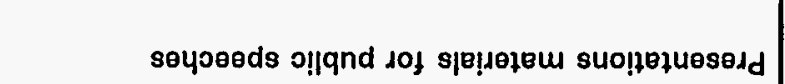 & $9 Z-3-a$ \\
\hline $\begin{array}{l}\text { t66 L Jejueno } \\
\text { puoves }\end{array}$ & se日ᄉojdur y y & 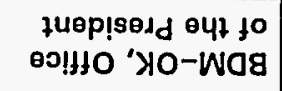 & Nouojew 7 & $Z$ 'ON LL OUMIOA 'SMON YGdIN & $9 Z-0-0$ \\
\hline $\begin{array}{r}766 \downarrow \\
\text { دelueno 1sג! }\end{array}$ & 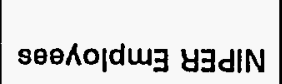 & 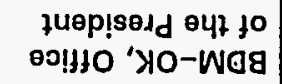 & Nouojew '7 & L'ON LL ounjon 'sMON YGJdIN & ヤて-の-ם \\
\hline sno!jen & 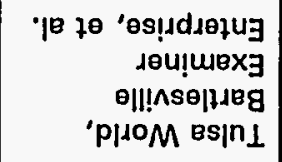 & 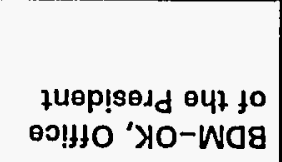 & 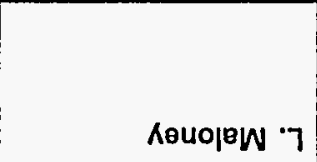 & sese日jed ssedd & $\varepsilon 乙-0-\square$ \\
\hline pejepun & 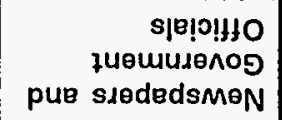 & Odg & - & 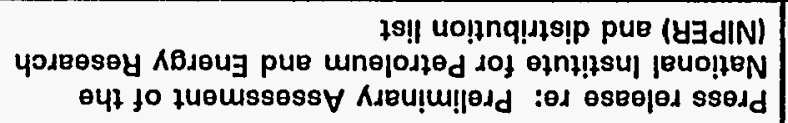 & Zて-0-a \\
\hline 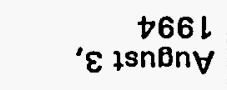 & $\begin{array}{r}\text { soonopduz } \\
\text { XO-Wag } \| \forall\end{array}$ & YO-Wag & вuog!a $\cdot 8$ & 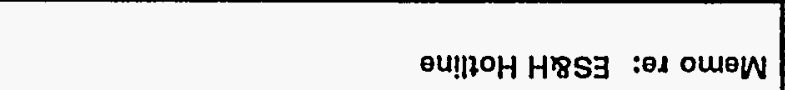 & レて-0-ם \\
\hline $766 \downarrow$ ' $8 \downarrow$ L $\Lambda$ n & $\begin{array}{r}\text { se日nojduz } \\
\text { YO-Wag } \| \forall\end{array}$ & $\begin{array}{l}\text { quep!seld out to } \\
\text { oग!fJO 'XO-WOa }\end{array}$ & вuog!a $\cdot 8$ & 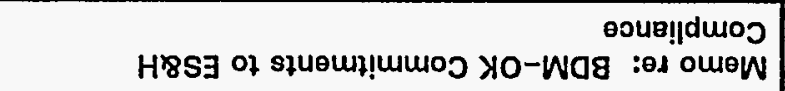 & $0 z-0-0$ \\
\hline $766 \mathrm{l}$ '0Z A $\mathrm{n} \mathrm{n} r$ & uo!łnq!גıs!a & H8S 'XO-Wag & & 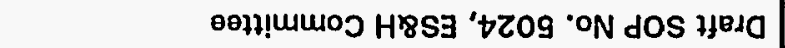 & $6 L-0-0$ \\
\hline $766 L^{\prime} t ! 1 \mathrm{~d} \forall$ & xo-wag & 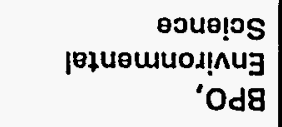 & นвแө|॥ : & 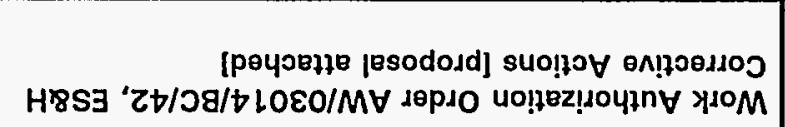 & $8 l-5-0$ \\
\hline †66l'† ABW & - & $\forall 0$ 'XO-wag & - & $\begin{array}{r}\text { sfueussess } \\
\text { quepuedepul ' } l \cdot l-0 l \cdot 009 \cdot 0 \mathrm{~N} \text { dOS Hesa }\end{array}$ & $\angle l-3-0$ \\
\hline $766\lfloor$ isnen $\forall$ & - & *o ‘xo-wag & - & 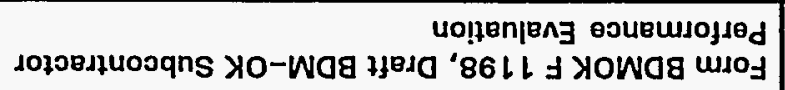 & $9 L-0-a$ \\
\hline upumoges & mughogug & 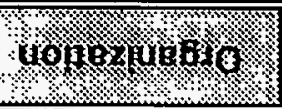 & 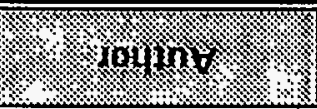 & \% & \% ninuogor \\
\hline
\end{tabular}


SITE DOCUMENTS THE ASSESSMENT TEAM REVIEWED (continued)

\begin{tabular}{|c|c|c|c|c|c|}
\hline Sogunorit & (1. & \%.6. & Orogargiog & roglom & Povinent: \\
\hline D-C-30 & Examples memos re: Acceptance of Deliverables & L. Gillham & PETC & B. DiBona & $\begin{array}{l}\text { May } 17 \text { and } \\
\text { June } 17 \text {. } \\
1994\end{array}$ \\
\hline D-C-31 & Memo re: ' Environmental protection & T. Wesson & $\begin{array}{l}\text { BPO, Office of the } \\
\text { Director }\end{array}$ & $\begin{array}{l}\text { All BPO and } \\
\text { BDM-OK } \\
\text { employees }\end{array}$ & June 8, 1994 \\
\hline D-C-32 & Memo re: Environmental management assessment & T. Wesson & $\begin{array}{l}\text { BPO, Office of the } \\
\text { Director }\end{array}$ & $\begin{array}{l}\text { All NIPER } \\
\text { personnel }\end{array}$ & $\begin{array}{l}\text { August } 9 \text {, } \\
1994\end{array}$ \\
\hline D-C-33 & $\begin{array}{l}\text { Memo re: Tank inspection by the Oklahoma } \\
\text { Corporation Commission }\end{array}$ & T. Bukoski & BDM-OK, ES\&H & B. DiBona & $\begin{array}{l}\text { August } 17 \\
1994\end{array}$ \\
\hline D-C-34 & ES\&H Procedure Status Tracking & - & BDM-OK, ES\&H & - & $\begin{array}{l}\text { August 19, } \\
1994\end{array}$ \\
\hline D-C-35 & $\begin{array}{l}\text { Letter re: Site visit and review of hazardous waste } \\
\text { management program }\end{array}$ & P. Montano & $\begin{array}{l}\text { Geoscience } \\
\text { Consultants, Ltd. }\end{array}$ & T. Bukoski & July 7, 1994 \\
\hline D-C-36 & $\begin{array}{l}\text { Draft Five Year Oil Implementation Plan Report, } \\
\text { Project Title: ES\&H and Quality Assurance } \\
\text { Responsibilities for Offsite Research }\end{array}$ & - & BDM-OK & - & Undated \\
\hline D-C-37 & $\begin{array}{l}\text { Work Request, Environment, Safety, Health, Security } \\
\text { and Quality Assurance }\end{array}$ & D. Alleman & $\begin{array}{l}\text { BPO, Environ- } \\
\text { mental Science }\end{array}$ & PETC & $\begin{array}{l}\text { January } 1 \\
1994\end{array}$ \\
\hline D-C-38 & Work Request, Environmental Protection & D. Alleman & $\begin{array}{l}\text { BPO, Environ- } \\
\text { mental Science }\end{array}$ & PETC & July 1, 1993 \\
\hline D-C-39 & $\begin{array}{l}\text { Work Request, Site Services (Safety, Health, } \\
\text { Environmental, Quality Assurance, Safeguards and } \\
\text { Security) }\end{array}$ & D. Alleman & $\begin{array}{l}\text { BPO, Environ- } \\
\text { mental Science }\end{array}$ & PETC & $\begin{array}{l}\text { August } 17 \\
.1994\end{array}$ \\
\hline D-C-40 & $\begin{array}{l}\text { Public relations slick sheet: Waste Hydrocarbons } \\
\text { Recycling }\end{array}$ & - & NIPER & $\begin{array}{l}\text { Available to the } \\
\text { general public }\end{array}$ & Undated \\
\hline D-C-41 & $\begin{array}{l}\text { Memo re: BDM-OK commitments to environment, } \\
\text { safety, and health compliance }\end{array}$ & B. DiBona & $\begin{array}{l}\text { BDM-OK, Office } \\
\text { of the President }\end{array}$ & $\begin{array}{l}\text { All BDM-OK } \\
\text { employees }\end{array}$ & July 18,1994 \\
\hline D-C-42 & $\begin{array}{l}\text { Memos re: Environmental, safety, \& health } \\
\text { compliance program review, April 28, } 1994\end{array}$ & B. DiBona & $\begin{array}{l}\text { BDM-OK, Office } \\
\text { of the President }\end{array}$ & Distribution & $\begin{array}{l}\text { March } 31 \text { and } \\
\text { May 2, } 1994\end{array}$ \\
\hline D-C-43 & Memo re: Permit tracking requirements & T. Bukoski & BDM-OK, ES\&H & J. Hughes & $\begin{array}{l}\text { August } 1 \text {. } \\
1994\end{array}$ \\
\hline
\end{tabular}




\begin{tabular}{|c|c|c|c|c|c|}
\hline peispun & Hełs jeusejul & Yxo-wag & чозрдвчо! 'H & 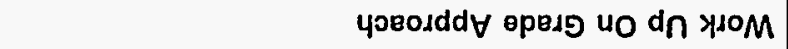 & $6-0-0$ \\
\hline peiepun & HEtS jButelu| & Yo-wog & чозрдвуэ! $\cdot H$ & 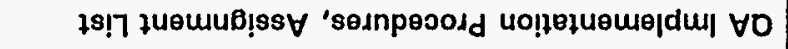 & $8-a-a$ \\
\hline pelepun & - & Y्र०-wag & !ysołng $\cdot 1$ & 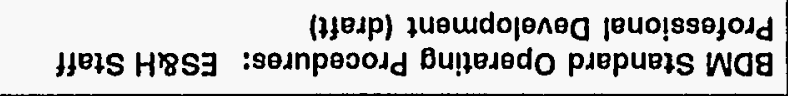 & $\angle-a-a$ \\
\hline $\begin{array}{r}\text { †66L } \\
\text { 'EL ounr }\end{array}$ & $\begin{array}{l}\text { s.eBibueW } \\
\text { Wag } \| \forall\end{array}$ & Y्र०-Wag & 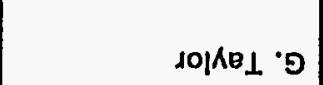 & 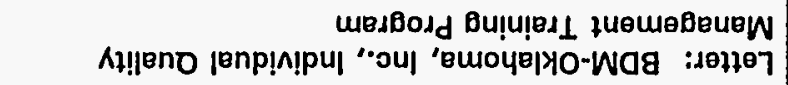 & $9-\mathrm{a}-\mathrm{a}$ \\
\hline t66l ounr & - & YO-Wag & - & 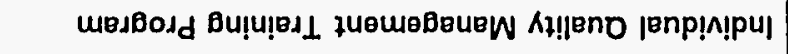 & $9-0-a$ \\
\hline $766 ! \| ! d \forall$ & - & Yo-wag & 一 & 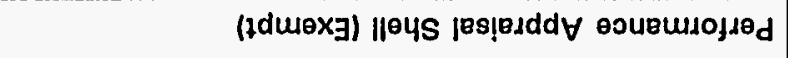 & $\nabla-0-0$ \\
\hline $766\llcorner\| 1 \mathrm{~d} \forall$ & - & Yo-wag & - & 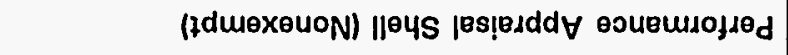 & $\varepsilon-0-0$ \\
\hline 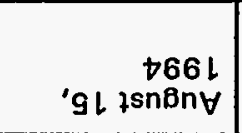 & 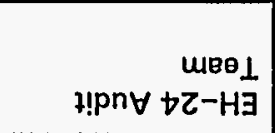 & 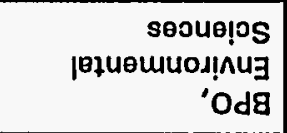 & 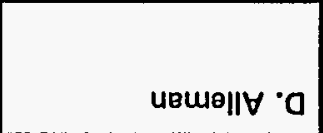 & 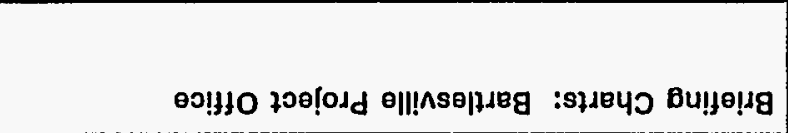 & $z-0-a$ \\
\hline 'gl tsnbny & 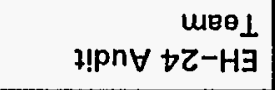 & H8S3'XO-Wa8 & $\begin{array}{r}\text { JeBgu日w } \\
\text { !ysoyng } 1\end{array}$ & 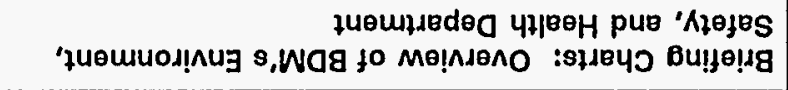 & $l-a-a$ \\
\hline$\left(\frac{1}{3}+4\right.$ & 6 & Whombing & 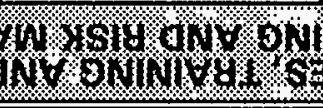 & 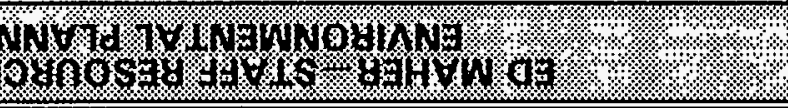 & 3 \\
\hline peғврun & - & $\exists \exists$ & - & 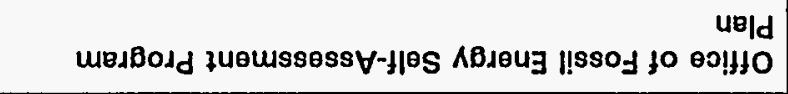 & $09-0-0$ \\
\hline pejepun & !ysoyng $\cdot 1$ & YO-Wog & - & 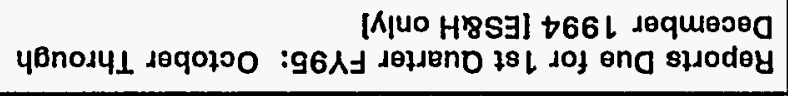 & $6 t-0-a$ \\
\hline pelepun & !ysoyng $\perp$ & Yo-was & - & 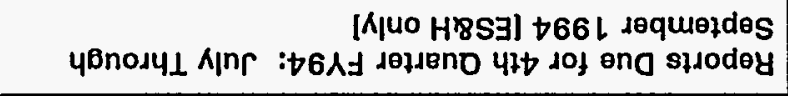 & $8 t-0-0$ \\
\hline $\begin{array}{r}766 \downarrow \\
\text { 'GL IsnBnt }\end{array}$ & ' & X्रo-wos & - & to se seuolsel!W pue słlodey jo yoollno $180-0 \varepsilon$ & $\angle t-0-0$ \\
\hline $\begin{array}{r}\text { quesdno } \\
\text { 'pӫвpun }\end{array}$ & - & XO-wog & - & 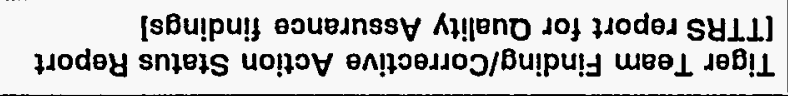 & $9 t-0-a$ \\
\hline $\begin{array}{r}\dagger 66 l \\
\square+\operatorname{snbn} \forall\end{array}$ & $\begin{array}{r}\text { seonojdur } \\
\text { YO-Wag IIV }\end{array}$ & 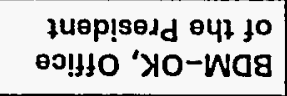 & вuog!a $\cdot \mathbf{g}$ & 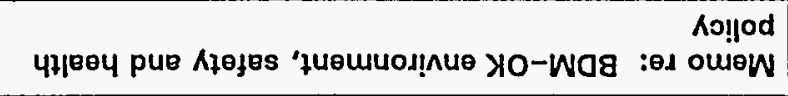 & $9 t-5-0$ \\
\hline Houtapos & yajolpas & upging & 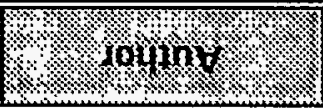 & 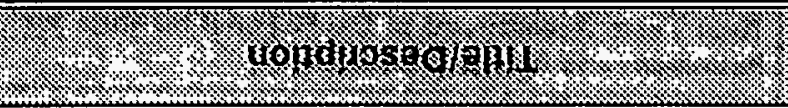 & Wunumoga \\
\hline
\end{tabular}


SITE DOCUMENTS THE ASSESSMENT TEAM REVIEWED (continued)

\begin{tabular}{|c|c|c|c|c|c|}
\hline pownoritis & \% & \%olwor. & Q19angaton & 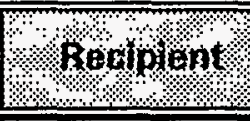 & poounerto \\
\hline D-D-10 & $\begin{array}{l}\text { BDM Standard Operating Procedures: Qualification } \\
\text { of Independent Assessment Personnel }\end{array}$ & H. Richardson & BDM-OK & - & May 17, 1994 \\
\hline D-D-11 & $\begin{array}{l}\text { Toxic Chemical and Hazardous Materials } \\
\text { Management and waste Disposal Plan }\end{array}$ & - & BDM-OK & - & May 1994 \\
\hline D-D-12 & Quality Assurance Program Plan & - & BDM-OK & - & Fobruary 1994 \\
\hline D-D-13 & BDM Quality Program & - & BDM-OK & - & Undated \\
\hline D-D-14 & 5480 Implementation Plans & - & BDM-OK & - & $\begin{array}{l}\text { December 23, } \\
1993\end{array}$ \\
\hline$D-D-15$ & Organizational Charts; Flow Charts & - & - & - & Various \\
\hline D-D-16 & Job Descriptions & & & & \\
\hline D-D-17 & $\begin{array}{l}\text { Memo re: FE Organizational Roles and } \\
\text { Responsibilities for ES\&H Activities at BPO/NIPER }\end{array}$ & - & - & - & April 10, 1994 \\
\hline D-D-18 & $\begin{array}{l}\text { Memo re: FE Organizational Roles and } \\
\text { Responsibilities for ES\&H Activities at BPO/NIPER }\end{array}$ & - & - & - & April 24, 1994 \\
\hline D-D-19 & $\begin{array}{l}\text { Memo re: Proposed Management and Operating } \\
\text { Contract for the National Oil and Related Programs }\end{array}$ & - & - & - & $\begin{array}{l}\text { September 24, } \\
1994\end{array}$ \\
\hline D-D-20 & $\begin{array}{l}\text { BDM Environmental, Safoty, and Health Self- } \\
\text { Assessment Plan }\end{array}$ & - & BDM-OK & - & March 1994 \\
\hline$D-D-21$ & $\begin{array}{l}\text { BDM Waste Minimization and Pollution Prevention } \\
\text { Awareness Plan }\end{array}$ & - & BDM-OK & - & June 1994 \\
\hline D-D-22 & BDM Quality Assurance Implementation Plan & - & BDM-OK & - & June 1994 \\
\hline D-D-23 & BDM Management Plan & - & BDM-OK & - & January 1994 \\
\hline D-D-24 & BDM Environmental Program Implementation Plan & - & BDM-OK & - & $\begin{array}{l}\text { December 23, } \\
1993\end{array}$ \\
\hline$D-D-25$ & BPO/NIPER Tiger Team Assessment Plan & - & - & - & $\begin{array}{l}\text { December } \\
1992\end{array}$ \\
\hline$D-D-26$ & $\begin{array}{l}\text { U.S. DOE Office of Environment, Safety and Health, } \\
\text { Tiger Team Assessment of the National Institute for } \\
\text { Petroleum and Energy Research }\end{array}$ & - & - & - & May 1992 \\
\hline
\end{tabular}




\begin{tabular}{|c|c|c|c|c|c|}
\hline $766\lfloor\operatorname{lin} r$ & - & YO-Wog & - & 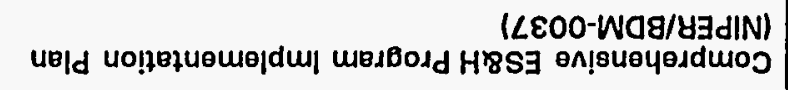 & Lt-a-a \\
\hline '81 Nieniqug & UOSION 'W & YO-WOg & чоspдвчอ! 'H & 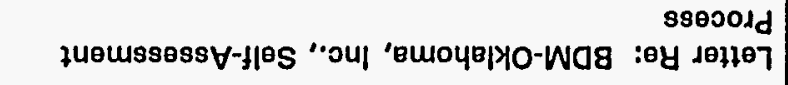 & $0 t-0-a$ \\
\hline perepun & - & Xo-wog & 8ภ07 0 & 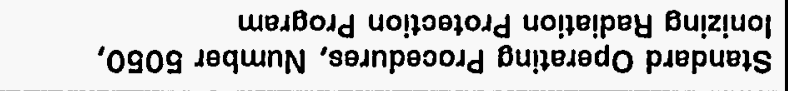 & $6 \varepsilon-0-0$ \\
\hline $\begin{array}{r}\varepsilon 66 L \\
\text { og oun }\end{array}$ & чвщө\| $\forall^{\circ} \mathrm{O}$ & Odg & Кө|медว $\forall$ & 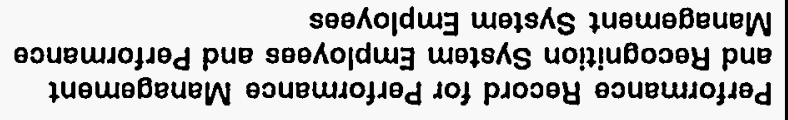 & $8 \varepsilon-a-a$ \\
\hline $\begin{array}{r}\varepsilon 66 l \\
' \varepsilon \text { dequeldes }\end{array}$ & - & Odg & - & 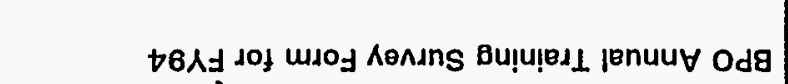 & $\angle \varepsilon-a-a$ \\
\hline †66 'oz A $\mathrm{n} r$ & யEบाI! · 7 & Yo-wag & Buog!a 'g & 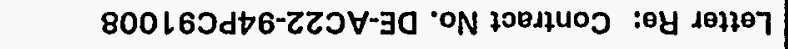 & $9 \varepsilon-a-a$ \\
\hline $766 L^{\prime} 8 L ! ! d \forall$ & Buog!a ' $\mathbf{g}$ & 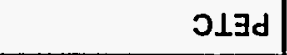 & щвчाI! • 7 & 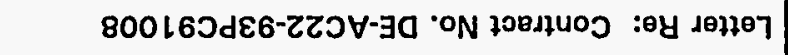 & $9 \varepsilon-a-a$ \\
\hline- & - & - & - & 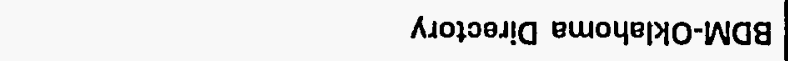 & $\downarrow \varepsilon-0-0$ \\
\hline- & - & 一 & - & spunspy & $\varepsilon \varepsilon-\mathrm{a}-\mathrm{a}$ \\
\hline $766 \mathrm{LEW}$ & - & - & - & 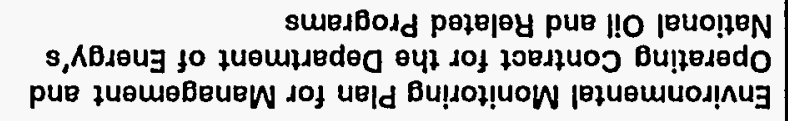 & $\tau \varepsilon-0-a$ \\
\hline- & - & - & - & 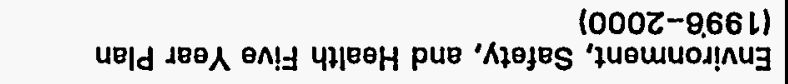 & $\llcorner\varepsilon-0-0$ \\
\hline - & 一 & - & - & lebeuew foe!̣dd :uo!fd!useg gor & $0 \varepsilon-0-a$ \\
\hline $766 \mathrm{~L}$ ' $2 \mathrm{KBW}$ & - & - & - & 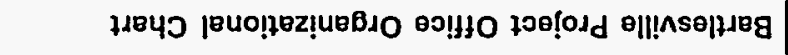 & $6 Z-0-a$ \\
\hline $\begin{array}{r}766 \downarrow \\
\text { ‘ }\end{array}$ & - & - & - & 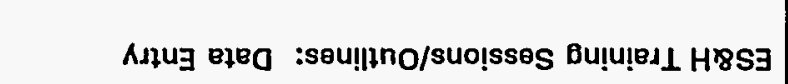 & $8 Z-0-0$ \\
\hline - & - & - & - & jenuew sodnposodd H8SG & $\angle Z-0-0$ \\
\hline Hopraga & pundogy & 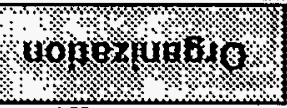 & $10,10 \%$ & 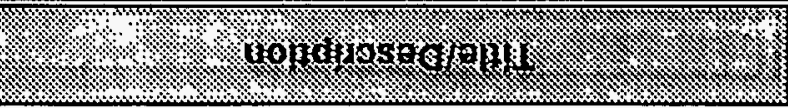 & Hownog \\
\hline
\end{tabular}


SITE DOCUMENTS THE ASSESSMENT TEAM REVIEWED (continued)

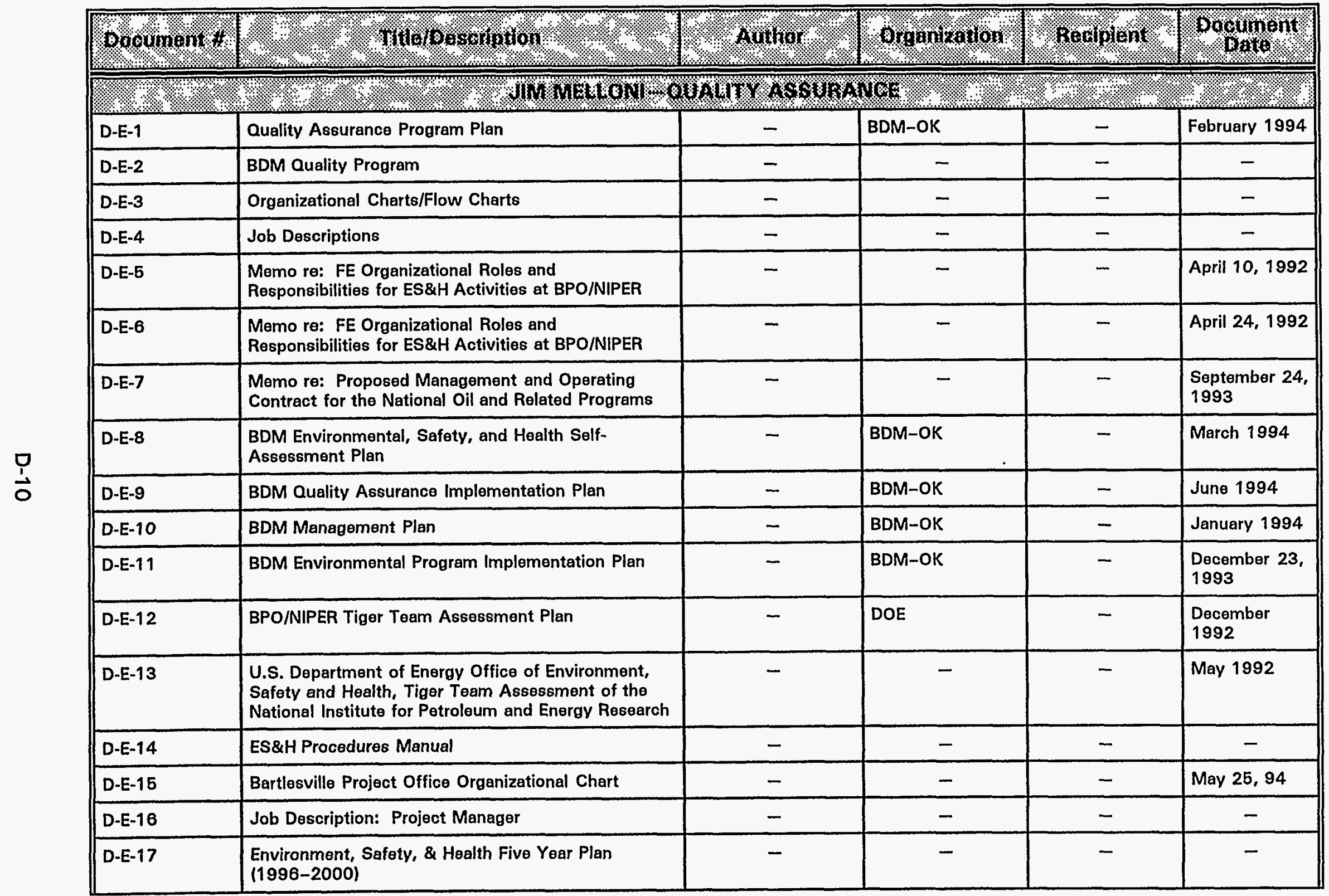




\section{SITE DOCUMENTS THE ASSESSMENT TEAM REVIEWED (continued)}

\begin{tabular}{|c|c|c|c|c|c|}
\hline ogomong & 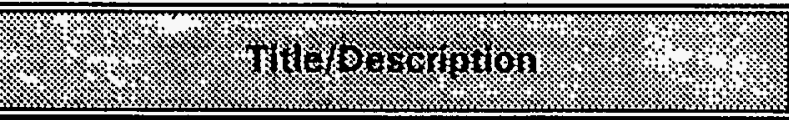 & $1 \%$ mar. & . & Roglplent & Dofunent \\
\hline D-E-18 & $\begin{array}{l}\text { Environmental Monitoring Plan for Management and } \\
\text { Operating Contract for the Dept. of Energy's National } \\
\text { Oil and Related Programs }\end{array}$ & - & - & - & May 1994 \\
\hline D-E-19 & Rósumés & - & - & - & - \\
\hline D-E-20 & BDM-Oklahoma Directory & - & - & - & - \\
\hline D-E-21 & Quality Assurance Assessment Plan & - & BDM-OK & - & - \\
\hline D-E-22 & Quality Assurance Implementation Plan & - & BDM-OK & - & June 1994 \\
\hline D-E-23 & QA Implementation Procedures & - & BDM-OK & - & - \\
\hline D-E-24 & Procurement Requisition & - & BDM-OK & - & April 1994 \\
\hline D-E-25 & $\begin{array}{l}\text { Bartlesville Project Office } \\
\text { Quality Assurance Program (Draft) }\end{array}$ & - & BPO & - & - \\
\hline D-E-26 & Letter: July 29, 1994 Weekly BPO-BDM QA Meeting & H. Richardson & BDM-OK & M. Nelson & $\begin{array}{l}\text { August } 1 \text {, } \\
1994\end{array}$ \\
\hline D-E-27 & Tiger Team Finding/Corrective Action Status Report & - & BDM-OK & - & - \\
\hline D-E-28 & $\begin{array}{l}\text { DOE-BPO/BDM-Oklahoma Calibration Committee } \\
\text { Meeting Minutes }\end{array}$ & - & BPO and BDM-OK & - & $\begin{array}{l}\text { August } 10 \\
1994\end{array}$ \\
\hline D-E-29 & Work Up On Graded Approach & - & BDM-OK & - & - \\
\hline D-E-30 & Quality Implementing Procedures & - & BDM-OK & - & - \\
\hline D-E-31 & Calibration System Requirements Manual & - & BDM-OK & - & - \\
\hline D-E-32 & $\begin{array}{l}\text { BDM-Oklahoma SOP-6100.6 DOE Tiger Team } \\
\text { Assessment Closure Plan }\end{array}$ & - & BDM-OK & - & - \\
\hline D-E-33 & QA Implementation Procedures Assignment List & 一 & BDM-OK & - & - \\
\hline D-E-34 & $\begin{array}{l}\text { Quality Assurance Program Plan for the Office of } \\
\text { Fossil Energy, Department of Energy }\end{array}$ & $\begin{array}{l}\text { Assistant Secretary } \\
\text { for Fossil Energy }\end{array}$ & DOE/FE & - & $\begin{array}{l}\text { March 3, } \\
1992\end{array}$ \\
\hline D-E-36 & Preparation of Standard Operating Procedures (SOP) & 一 & BDM-OK & - & July 20,1994 \\
\hline D-E-36 & $\begin{array}{l}\text { Milestone Report: QA3-Incorporate Environmental } \\
\text { Quality Assurence Requirements }\end{array}$ & - & BPO & - & May 12,1994 \\
\hline
\end{tabular}


SITE DOCUMENTS THE ASSESSMENT TEAM REVIEWED (continued)

\begin{tabular}{|c|c|c|c|c|c|}
\hline Pacimant & (4) & (3.) Gunor. & organikgtion & romplont, & sogunonit \\
\hline D-E-37 & $\begin{array}{l}\text { RFP: DE-RP22-92PC91008 Part IV-Section L } \\
\text { Attachment } 8\end{array}$ & - & DOE & - & - \\
\hline D-E-38 & Memo re: TOM Training & B. DiBona & BDM-OK & & $\begin{array}{l}\text { February } 7 \\
1994\end{array}$ \\
\hline D-E-39 & Position Description: Systems Quality Engineer & - & BDM-OK & - & - \\
\hline D-E-40 & $\begin{array}{l}\text { Statement of Work: DE-AC22-94PC91008 Part III } \\
\text { Section J Appendix D }\end{array}$ & - & DOE & - & - \\
\hline D-E-41 & $\begin{array}{l}\text { Agenda: DOE-BPO/BDM-Oklahoma Weekly Quality } \\
\text { Assurance Meeting }\end{array}$ & - & BPO/BDM-OK & - & $\begin{array}{l}\text { August 19, } \\
1994\end{array}$ \\
\hline D-E-42 & $\begin{array}{l}\text { Quality Assurance Accomplishments and } \\
\text { Deficiencies }\end{array}$ & - & BDM-OK & - & $\begin{array}{l}\text { Week of } \\
\text { August } 16 \text {, } \\
1994\end{array}$ \\
\hline D-E-43 & Letter re: Acceptance of Deliverables & L. Gillham & PETC & B. DiBona & May 17,1994 \\
\hline 2 & (., & 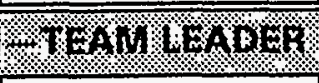 & 1. & & \\
\hline D-F-1 & $\begin{array}{l}\text { Memo re: FE Organizational Roles and } \\
\text { Responsibilities for ES\&H Activities at BPO/NIPER }\end{array}$ & J. Randolph & FE-1 & T. Wesson, BPO & April 10, 1992 \\
\hline
\end{tabular}




\section{APPENDIX E}

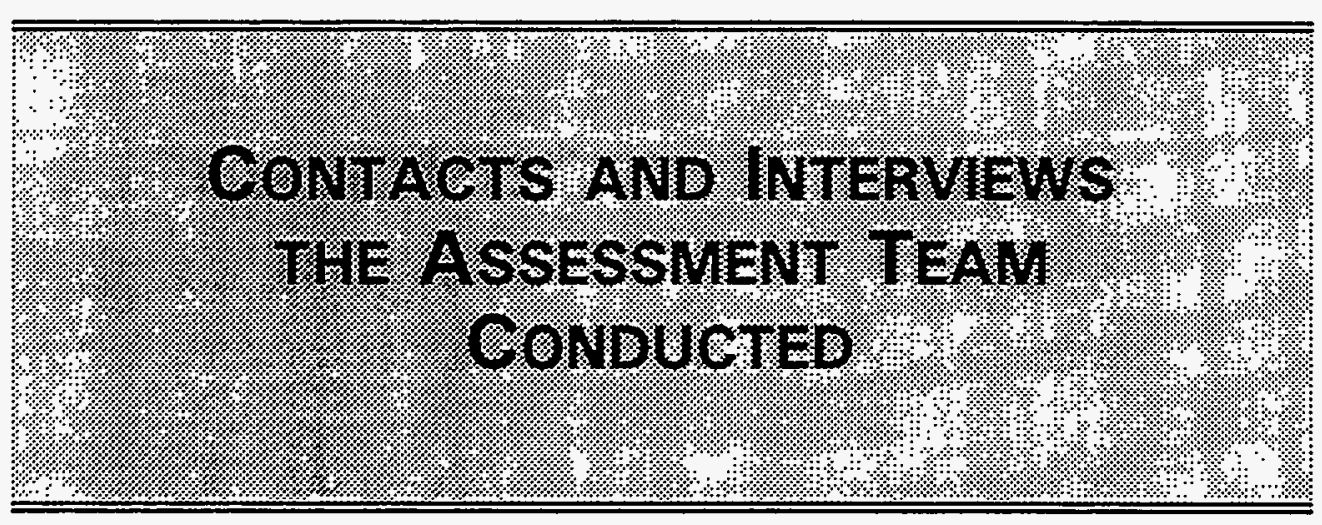


Page intentionally blank 
CONTACTS AND INTERVIEWS THE ASSESSMENT TEAM CONDUCTED

\begin{tabular}{|c|c|c|c|c|}
\hline $3 \%$ & \% & 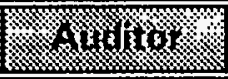 & 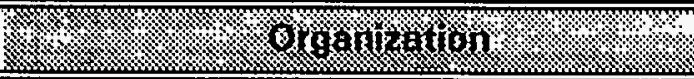 & 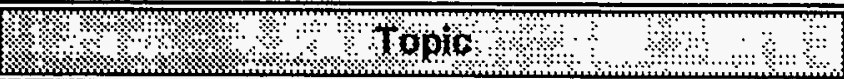 \\
\hline \multicolumn{5}{|l|}{ 1. } \\
\hline I-A-1 & $8 / 15 / 94$ & R. Gupta & BDM-OK & Organizational structure; environmental commitment \\
\hline 1-A-2 & $8 / 15 / 94$ & R. Gupta & BDM-OK, ES\&H & Organizational structure; environmental commitment \\
\hline $1-A-3$ & $8 / 15 / 94$ & R. Gupta & BPO, Office of the Director & Organizational structure; environmental commitment \\
\hline I-A-4 & $8 / 16 / 94$ & R. Gupta & BPO, AEPT & Organizational structure; environmental commitment \\
\hline 1-A-5 & $8 / 16 / 94$ & R. Gupta & BPO, QA/OC & Organizational structure \\
\hline I-A-6 & $8 / 16 / 94$ & R. Gupta & BDM-OK, Processing \& Utilization Department & Organizational structure; environmental commitment \\
\hline $1-A-7$ & $8 / 16 / 94$ & R. Gupta & BDM-OK, Processing \& Utilization Department & Organizational structure; environmental commitment \\
\hline 1-A-8 & $8 / 17 / 94$ & R. Gupta & BPO, Office of the Director & Organizational structure \\
\hline I-A-9 & $8 / 18 / 94$ & R. Gupta & BPO, AEPT & Organizational structure \\
\hline I-A-10 & $8 / 17 / 94$ & R. Gupta & BDM-OK, Fuels \& Engine Testing Department & Environmental commitment \\
\hline I-A-11 & $8 / 17 / 94$ & R. Gupta & BDM-OK, Fuels \& Engine Testing Department & Environmentel commitment \\
\hline I-A-12 & $8 / 17 / 94$ & R. Gupta & FE, Office of Self Assessment & Organizational structure \\
\hline $1-A-13$ & $8 / 18 / 94$ & R. Gupta & BPO, AEPT & Organizational structure \\
\hline I-A-14 & $8 / 18 / 94$ & R. Gupta & BPO, Office of Administration & Organizational structure \\
\hline I-A-15 & $8 / 18 / 94$ & R. Gupta & PETC & Organizational structure \\
\hline I-A-16 & $8 / 19 / 94$ & R. Gupta & BPO, Office of the Director & Organizational structure \\
\hline $1-A-17$ & $8 / 19 / 94$ & R. Gupta & BPO, AEPT & Organizational structure \\
\hline I-A-18 & $8 / 19 / 94$ & R. Gupta & BDM, Office of the President & Organizational structure \\
\hline I-A-19 & $8 / 22 / 94$ & R. Gupta & BDM, Administration and Facilities Department & Organizational structure \\
\hline
\end{tabular}


CONTACTS AND INTERVIEWS THE ASSESSMENT TEAM CONDUCTED (continued)

\begin{tabular}{|c|c|c|c|c|}
\hline \multicolumn{3}{|c|}{ 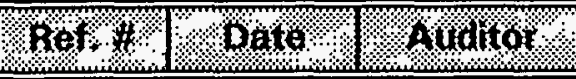 } & 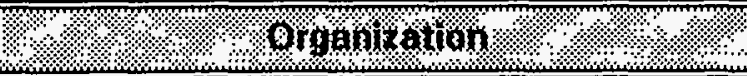 & \\
\hline \multicolumn{5}{|c|}{ ? } \\
\hline I-B-1 & $8 / 15 / 94$ & S. Gnewuch & BPO, AEPT & $\begin{array}{l}\text { Environmental protection program; formality of } \\
\text { environmental programs }\end{array}$ \\
\hline I-B-2 & $8 / 15 / 94$ & S. Gnewuch & $\begin{array}{l}\text { BDM-OK, Petroleum Program Integration } \\
\text { Department }\end{array}$ & $\begin{array}{l}\text { Environmental protection program; formality of } \\
\text { environmental programs }\end{array}$ \\
\hline I-B-3 & $8 / 16 / 94$ & S. Gnewuch & BDM-OK, ES\&H & $\begin{array}{l}\text { Environmental protection program; formality of } \\
\text { environmental programs }\end{array}$ \\
\hline 1-B-4 & $8 / 16 / 94$ & S. Gnowuch & BPO, Office of the Director & $\begin{array}{l}\text { Environmental protection program; formality of } \\
\text { environmental programs }\end{array}$ \\
\hline I-B-5 & $8 / 16 / 94$ & S. Gnewuch & BDM-OK, ES\&H & $\begin{array}{l}\text { Environmental protection program; formality of } \\
\text { environmental programs }\end{array}$ \\
\hline I-B-6 & $8 / 16 / 94$ & S. Gnewuch & BPO, EOR & $\begin{array}{l}\text { Environmental protection program; formality of } \\
\text { environmental programs }\end{array}$ \\
\hline 1-B-7 & $8 / 17 / 94$ & S. Gnewuch & BPO, Office of the Director & $\begin{array}{l}\text { Environmental protection program; formality of } \\
\text { environmental programs }\end{array}$ \\
\hline I-B-8 & $8 / 17 / 94$ & S. Gnowuch & BPO, AEPT & $\begin{array}{l}\text { Environmental protection program; formality of } \\
\text { environmental programs }\end{array}$ \\
\hline I-B-9 & $8 / 17 / 94$ & S. Gnowuch & BDM-OK, Administration \& Facilities Department & $\begin{array}{l}\text { Environmental protection program; formality of } \\
\text { environmental programs }\end{array}$ \\
\hline I-B-10 & $8 / 17 / 94$ & S. Gnowuch & BPO, AEPT & $\begin{array}{l}\text { Environmental protection program; formality of } \\
\text { environmental programs }\end{array}$ \\
\hline \multicolumn{5}{|c|}{ (2. } \\
\hline $1-C-1$ & $8 / 15 / 94$ & R. Roid & BDM-OK, ES\&H & $\begin{array}{l}\text { Self-assessment activities; communication with BPO } \\
\text { and outside agencies }\end{array}$ \\
\hline $1-C-2$ & $8 / 15 / 94$ & R. Roid & BDM-OK, Office of the President & $\begin{array}{l}\text { External communication; communication with BPO and } \\
\text { BDM-OK ES\&H Dept. }\end{array}$ \\
\hline $1-C-3$ & $8 / 15 / 94$ & R. Reid & BDM-OK, ES\&H & $\begin{array}{l}\text { Self-assessment activities; oversight activities; } \\
\text { communication with BPO and outside agencies }\end{array}$ \\
\hline
\end{tabular}


CONTACTS AND INTERVIEWS THE ASSESSMENT TEAM CONDUCTED (continued)

\begin{tabular}{|c|c|c|c|c|}
\hline 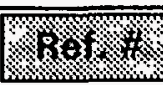 & 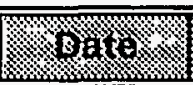 & 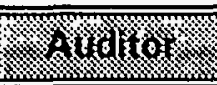 & 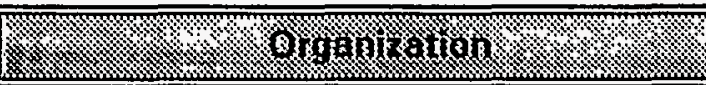 & 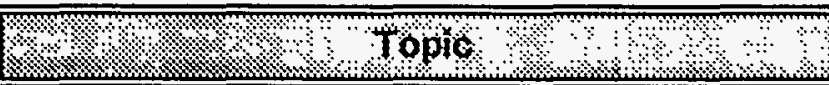 \\
\hline I-C-4 & $8 / 16 / 94$ & R. Reid & BDM-OK, Office of the President & $\begin{array}{l}\text { Public relations; communication with BDM-OK ES\&H } \\
\text { Dept., other BDM-OK employees, BPO }\end{array}$ \\
\hline I-C-5 & $8 / 16 / 94$ & R. Reid & BDM-OK, QA & $\begin{array}{l}\text { BDM-OK QA Dept. role in BDM-OK self-assessment } \\
\text { activities; subcontractor oversight }\end{array}$ \\
\hline 1-C-6 & $8 / 16 / 94$ & R. Reid & BPO, AEPT & $\begin{array}{l}\text { Self-assessment and over-sight activities; } \\
\text { communication with BDM-OK and outside agencies }\end{array}$ \\
\hline $1-C-7$ & $8 / 16 / 94$ & R. Roid & BPO, EOR & Technology transfer; public relations \\
\hline 1-C-8 & $8 / 16 / 94$ & R. Reid & BPO, Office of the Director & Internal reporting expectations; public relations \\
\hline I-C-9 & $8 / 17 / 94$ & R. Roid & BPO, OA/QC & $\begin{array}{l}\text { Plans for integrating QA Office activities into } \\
\text { environmental oversight }\end{array}$ \\
\hline $1-C-10$ & $8 / 17 / 94$ & R. Reid & $\begin{array}{l}\text { BDM-OK, Petroleum Program Integration } \\
\text { Department }\end{array}$ & $\begin{array}{l}\text { Communication with MSO and Metairie BDM-OK } \\
\text { employees; subcontract program evaluation }\end{array}$ \\
\hline $1-C-11$ & $8 / 17 / 94$ & R. Roid & BDM-OK, Petroleum Technology Department & $\begin{array}{l}\text { ES\&H Committeo; Environmental Coordinator Program; } \\
\text { environmental communication; lateral communication }\end{array}$ \\
\hline I-C-12 & $8 / 17 / 94$ & R. Reid & BDM-OK, Petroleum Technology Depertment & Environmental communication \\
\hline 1-C-13 & $8 / 17 / 94$ & R. Roid & BDM-OK, Petroloum Technology Department & Environmental communication \\
\hline $1-C-14$ & $8 / 17 / 94$ & R. Reid & BDM-OK, Petroleum Technology Department & Environmental communication \\
\hline $1-C-15$ & $8 / 17 / 94$ & R. Reid & $\begin{array}{l}\text { BDM-OK, Petroleum Program Integration } \\
\text { Department }\end{array}$ & TTRS; BCATS \\
\hline $1-C-16$ & $8 / 17 / 94$ & R. Roid & PETC & $\begin{array}{l}\text { Contract requirements for regulatory interface and } \\
\text { internal reporting }\end{array}$ \\
\hline $1-C-17$ & $8 / 18 / 94$ & R. Reid & BDM-OK, Office of the President & Followup interview \\
\hline I-C-18 & $8 / 18 / 94$ & R. Reid & PETC & $\begin{array}{l}\text { Contract requirements for regulatory interface and } \\
\text { internal reporting }\end{array}$ \\
\hline $1-C-19$ & $8 / 18 / 94$ & R. Roid & $\begin{array}{l}\text { BDM-OK, Petroleum Program Integration } \\
\text { Depertment }\end{array}$ & Offsite subcontract program evaluation \\
\hline $1-C-20$ & $8 / 18 / 94$ & R. Reid & BDM-OK, ES\&H & Followup interview \\
\hline $1-C-21$ & $8 / 18 / 94$ & R. Roid & BDM-OK, ES\&H & Followup interview \\
\hline $1-\mathrm{C}-22$ & $8 / 19 / 94$ & R. Roid & Oklahoma Department of Environmental Quality & Interface with BPO and BDM-OK \\
\hline
\end{tabular}


CONTACTS AND INTERVIEWS THE ASSESSMENT TEAM CONDUCTED (continued)

\begin{tabular}{|c|c|c|c|c|}
\hline Pot & Bato & Hugrtor & W. & \% \\
\hline I-C-23 & $8 / 19 / 94$ & R. Reid & $\begin{array}{l}\text { Wheelabrator EOS, Inc., operating contractor for } \\
\text { the City of Bartlesville Utilities }\end{array}$ & Interface with BPO and BDM-OK \\
\hline $1-C-24$ & $8 / 19 / 94$ & R. Reid & BPO, AEPT & Followup interview \\
\hline $1-C-25$ & $8 / 19 / 94$ & R. Reid & BDM-OK, ES\&H & Documentation of discussion with regulators \\
\hline \multicolumn{5}{|c|}{ 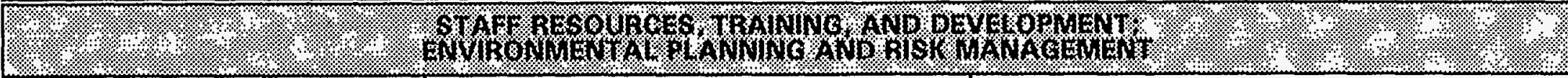 } \\
\hline I-D-1 & $8 / 15 / 94$ & E. Maher & BDM-OK, Administration \& Facilities Department & Staff resources, training, and development \\
\hline I-D-2 & $8 / 15 / 94$ & E. Maher & BDM-OK, Office of the President & $\begin{array}{l}\text { Staff resources; environmental planning and risk } \\
\text { management }\end{array}$ \\
\hline I-D-3 & $8 / 16 / 94$ & E. Maher & BPO, AEPT & $\begin{array}{l}\text { Environmental planning; risk management; staff } \\
\text { development; employee awards and incentives }\end{array}$ \\
\hline I-D-4 & $8 / 16 / 94$ & E. Maher & BDM-OK, Processing \& Utilization Department & Staff environmental training and resources \\
\hline I-D-6 & $8 / 16 / 94$ & E. Maher & BDM-OK, ES\&H & $\begin{array}{l}\text { Staff resources, training, and development; } \\
\text { environmental planning and risk management }\end{array}$ \\
\hline 1-D-6 & $8 / 16 / 94$ & E. Maher & BDM-OK, QA & $\begin{array}{l}\text { Staff training and development quality assurance plans; } \\
\text { risk management quality plans }\end{array}$ \\
\hline I-D-7 & $8 / 17 / 94$ & E. Maher & BDM-OK, Administration \& Facilities Department & Budget tracking; environmental planning \\
\hline I-D-8 & $8 / 17 / 94$ & E. Maher & BPO, QA/QC & Quality assurance in EH\&S activities \\
\hline I-D-8 & $8 / 17 / 94$ & E. Maher & BDM-OK, ES\&H & Risk management; environmental planning \\
\hline I-D-10 & $8 / 17 / 94$ & E. Maher & BPO, AEPT & Budget tracking of ES\&H activities \\
\hline I-D-11 & $8 / 17 / 94$ & E. Maher & BPO, Office of Administration & Budgat obligation authority; training; staff dovelopment \\
\hline I-D-12 & $8 / 18 / 94$ & E. Maher & BPO, Office of the Director & Financial authority; risk management; PETC coordination \\
\hline I-D-13 & $8 / 18 / 94$ & E. Maher & BDM-OK, Administration \& Facilities Department & Safety training and documentation; ES\&H support \\
\hline I-D-14 & $8 / 18 / 94$ & E. Maher & BDM-OK, ES\&H & $\begin{array}{l}\text { Environmental radioactivity; mixed waste; X-ray } \\
\text { protection }\end{array}$ \\
\hline I-D-15 & $8 / 18 / 94$ & E. Maher & PETC & PETC financial oversight roles; budget tracking \\
\hline
\end{tabular}


CONTACTS AND INTERVIEWS THE ASSESSMENT TEAM CONDUCTED (continued)

\begin{tabular}{|c|c|c|c|c|}
\hline 8.6. & Batite & 8.8. & (1) & 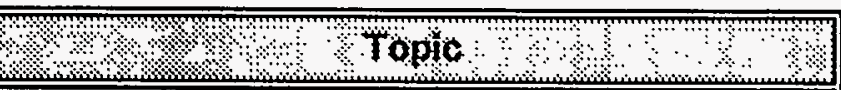 \\
\hline lis. & 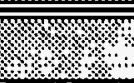 & 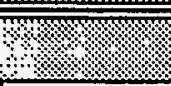 & (4). & 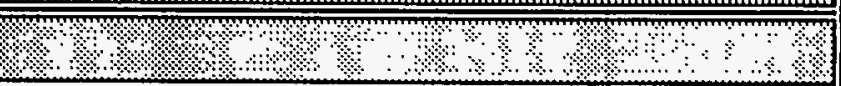 \\
\hline I-E-1 & $8 / 15 / 84$ & J. Melloni & $B P O, O A / O C$ & QA Program \\
\hline I-E-2 & $8 / 16 / 94$ & J. Melloni & $B D M-O K, Q A$ & QA Program \\
\hline I-E-3 & $8 / 16 / 94$ & J. Melloni & BDM-OK, Office of the President & QA Program \\
\hline I-E-4 & $8 / 16 / 94$ & J. Melloni & BDM-OK, ES\&H & QA Oversight \\
\hline I-E-5 & $8 / 16 / 94$ & J. Melloni & BDM-OK, Administration \& Facilities Department & Procurement Quality \\
\hline I-E-6 & $8 / 16 / 94$ & J. Melloni & BPO, AEPT & QA Oversight \\
\hline I-E-7 & $8 / 17 / 94$ & J. Melloni & BPO, Office of the Director & QA Program \\
\hline I-E-8 & $8 / 17 / 94$ & J. Melloni & BDM-OK, QA & QA Program \\
\hline I-E-9 & $8 / 17 / 94$ & J. Melloni & BDM-OK, QA & QA Responsibilities \\
\hline I-E-10 & $8 / 17 / 94$ & J. Melloni & BDM-OK, OA & QA Program \\
\hline I-E-11 & $8 / 17 / 94$ & J. Melloni & BDM-OK, Administration \& Facilities & Document \& Record Control \\
\hline I-E-12 & $8 / 18 / 94$ & J. Melloni & BPO, AEPT & QA History \\
\hline I-E-13 & 8/18/94 & J. Melloni & BDM-OK, QA & QA Program \\
\hline I-E-14 & $8 / 18 / 94$ & J. Melloni & $B P O, Q A / O C$ & QA Program \\
\hline I-E-15 & $8 / 19 / 94$ & J. Melloni & BDM-OK, OA & Weekly QA Meoting \\
\hline I-E-16 & $8 / 19 / 94$ & J. Melloni & $\mathrm{BPO}, \mathrm{QA} / \mathrm{OC}$ & Weokly QA Meeting \\
\hline I-E-17 & $8 / 19 / 94$ & J. Melloni & BDM-OK, QA & Wookly QA Meoting \\
\hline I-E-18 & $8 / 19 / 94$ & J. Melloni & BDM-OK, QA & Woekly OA Meeting \\
\hline 12 & $\sqrt[3]{1.0}$ & $\sqrt{1.9}$ & :. & $4.1 \%$ \\
\hline I-F-1 & $7 / 20 / 94$ & R. Green & DOE/Office of Self Assessment (FE-6) & Duties related to BPO \\
\hline I-F-2 & $7 / 20 / 94$ & R. Green & DOE/Office of Oil \& Gas Processing (FE-32) & Duties related to BPO \\
\hline
\end{tabular}





\section{APPENDIX F}

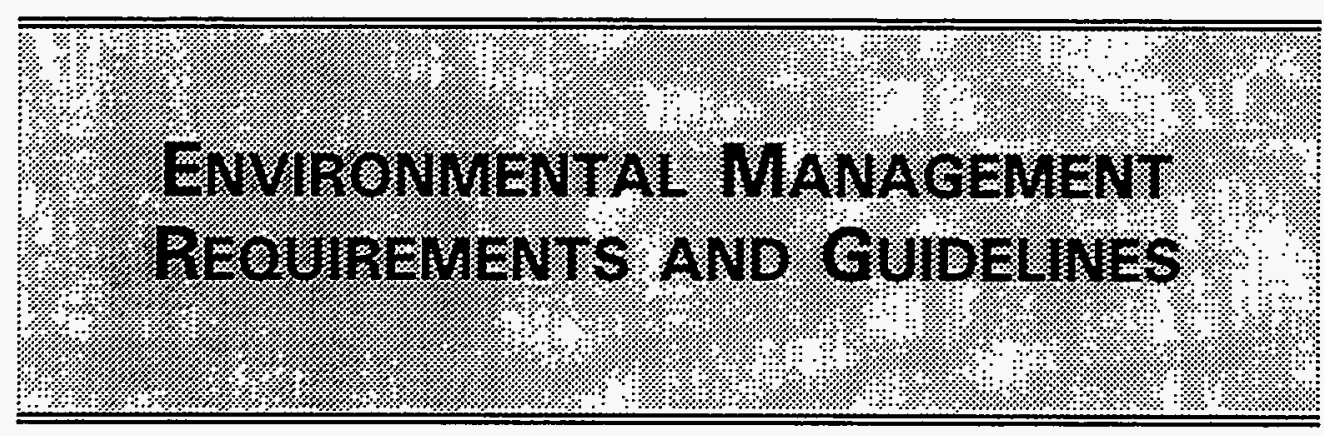


Page intentionally blank

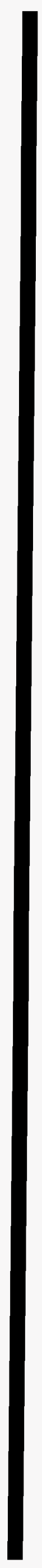


ENVIRONMENTAL MANAGEMENT

REQUIREMENTS AND GUIDELINES

\begin{tabular}{|c|c|c|}
\hline 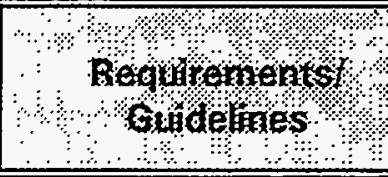 & $\begin{array}{l}\text { (3) } \\
\text { (1) }\end{array}$ & 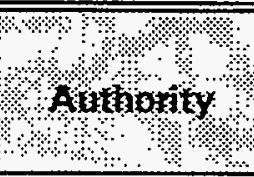 \\
\hline $\begin{array}{l}\text { Executive Orders } \\
11514 \text { and } 11991\end{array}$ & $\begin{array}{l}\text { Protection and Enhancement of Environmental } \\
\text { Quality }\end{array}$ & $\begin{array}{l}\text { Office of the } \\
\text { President }\end{array}$ \\
\hline $\begin{array}{l}\text { Executive Order } \\
12088\end{array}$ & $\begin{array}{l}\text { Federal Compliance with Pollution Control } \\
\text { Standards }\end{array}$ & $\begin{array}{l}\text { Office of the } \\
\text { President }\end{array}$ \\
\hline $\begin{array}{l}\text { Executive Order } \\
12586\end{array}$ & $\begin{array}{l}\text { Federal Compliance with Right-to-Know Laws } \\
\text { and Pollution Prevention Requirements }\end{array}$ & $\begin{array}{l}\text { Office of the } \\
\text { President }\end{array}$ \\
\hline Public Law 102-386 & Federal Facilities Compliance Act & EPA \\
\hline $\begin{array}{l}33 \text { U.S.C. } 1251 \\
\text { et seq. }\end{array}$ & Clean Water Act & EPA \\
\hline 40 U.S.C. 9601 & $\begin{array}{l}\text { Comprehensive Environmental Response, } \\
\text { Compensation, and Liability Act, Section 120, } \\
\text { Federal Facilities }\end{array}$ & EPA \\
\hline $\begin{array}{l}42 \text { U.S.C. } 6901 \\
\text { et seq. }\end{array}$ & Resource Conservation and Recovery Act & EPA \\
\hline $\begin{array}{l}42 \text { U.S.C. } 7401 \\
\text { et seq. }\end{array}$ & Clean Air Act & EPA \\
\hline $\begin{array}{l}42 \text { U.S.C. } 13101- \\
13109\end{array}$ & Pollution Prevention Act & EPA \\
\hline 29 CFR 1910.120 & $\begin{array}{l}\text { Hazardous Waste Operations and Emergency } \\
\text { Response }\end{array}$ & OSHA \\
\hline 40 CFR 50 & National Ambient Air Quality Standards & EPA \\
\hline 40 CFR 58 & Ambient Air Quality Surveillance & EPA \\
\hline 40 CFR 60 & $\begin{array}{l}\text { Standards of Performance for New Stationary } \\
\text { Sources }\end{array}$ & EPA \\
\hline 40 CFR 61 & $\begin{array}{l}\text { National Emission Standards for Hazardous Air } \\
\text { Pollutants }\end{array}$ & EPA \\
\hline 40 CFR 82 & Protection of Stratospheric Ozone & EPA \\
\hline 40 CFR 110 & Discharge of Oil & EPA \\
\hline 40 CFR 112 & Oil Pollution Prevention & EPA \\
\hline 40 CFR 121 & $\begin{array}{l}\text { State Certification of Activities Requiring a } \\
\text { Federal License or Permit }\end{array}$ & EPA \\
\hline 40 CFR $122 / 123$ & $\begin{array}{l}\text { National Pollutant Discharge Elimination } \\
\text { System (NPDES)/State Pollutant Discharge } \\
\text { Elimination System (SPDES) }\end{array}$ & EPA \\
\hline
\end{tabular}




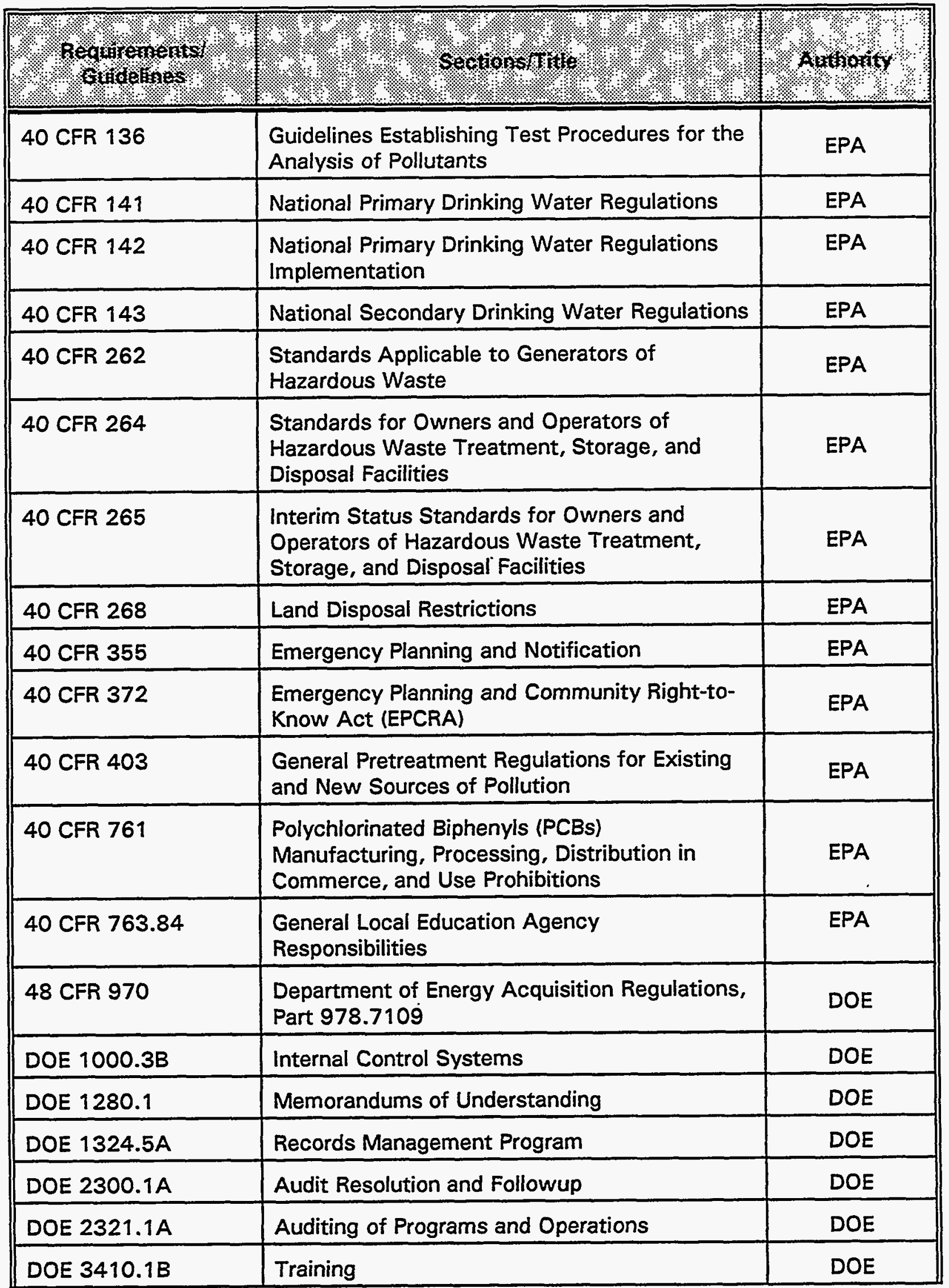


ENVIRONMENTAL MANAGEMENT

REQUIREMENTS AND GUIDELINES (continued)

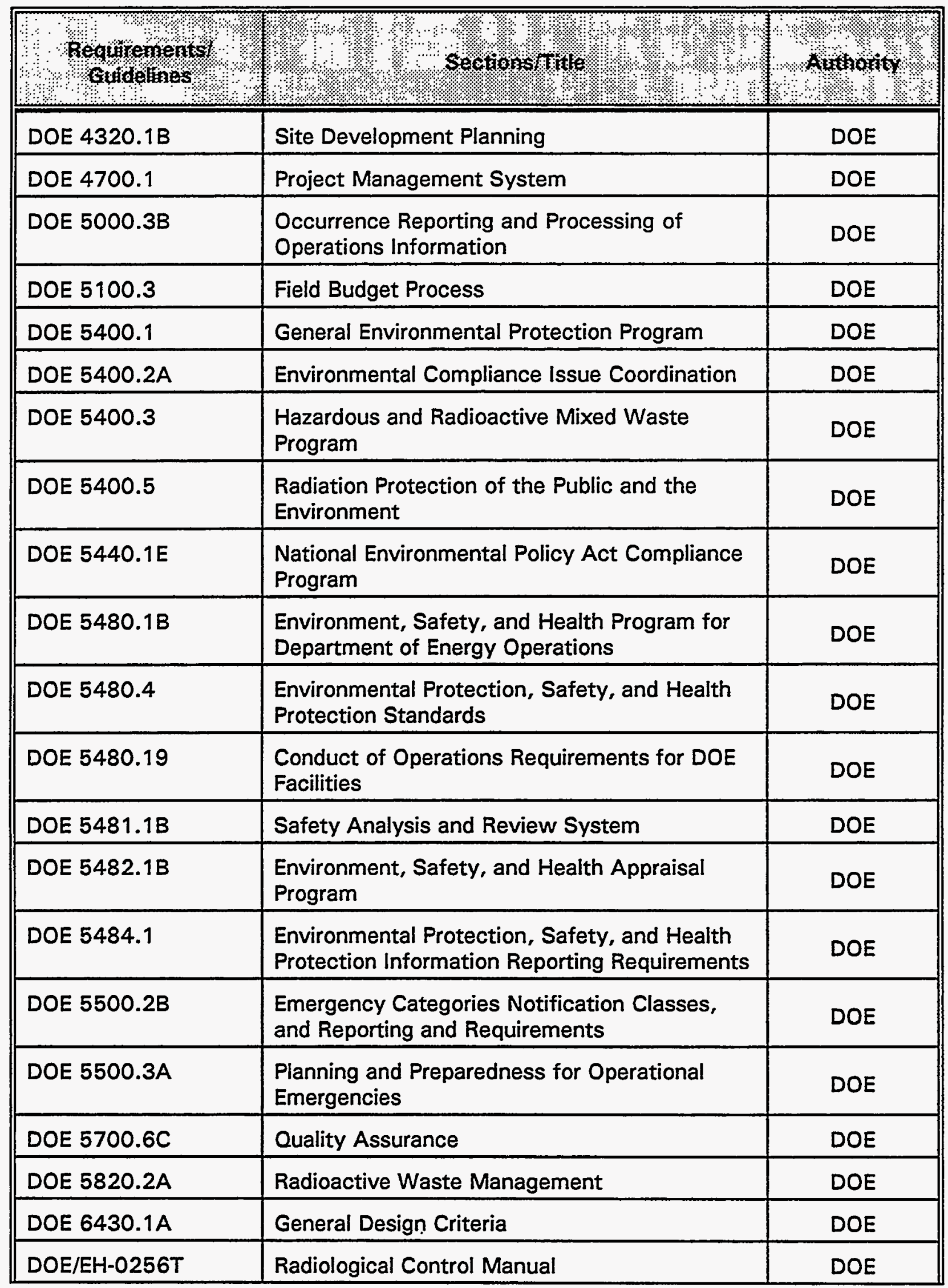




\begin{tabular}{|c|c|c|}
\hline 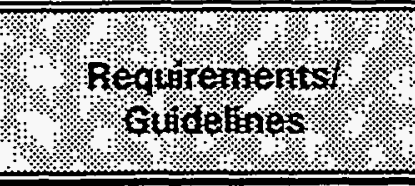 & (3. & A.ton \\
\hline DOE/EH-0326 & $\begin{array}{l}\text { Protocols for Conducting Environmental } \\
\text { Management Assessments of DOE } \\
\text { Organizations }\end{array}$ & DOE \\
\hline DOE/EH-0358 & $\begin{array}{l}\text { Performance Objectives and Criteria for } \\
\text { Conducting DOE Environmental Audits }\end{array}$ & DOE \\
\hline $\begin{array}{l}\text { January } 1994 \\
\text { Draft Final }\end{array}$ & DOE Environmental Audit Program Guidance & DOE \\
\hline $\begin{array}{l}\text { January } 26,1990, \\
\text { Secretarial } \\
\text { Memorandum }\end{array}$ & $\begin{array}{l}\text { Preliminary Review of Trends in Tiger Team } \\
\text { Assessments }\end{array}$ & DOE \\
\hline $\begin{array}{l}\text { July } 31,1990, \\
\text { Secretarial } \\
\text { Memorandum }\end{array}$ & $\begin{array}{l}\text { Guidance on Environment, Safety, and Health } \\
\text { (ES\&H) Self-Assessment }\end{array}$ & DOE \\
\hline $\begin{array}{l}\text { Interim Guide } \\
\text { March 8, } 1991\end{array}$ & $\begin{array}{l}\text { DOE Guidance on the Procedures in Applying } \\
\text { the ALARA Process for Compliance with DOE } \\
5400.5\end{array}$ & DOE \\
\hline $\begin{array}{l}\text { December } 1992 \\
\text { Guidance }\end{array}$ & Self-Assessment Guidance Document & DOE \\
\hline $\begin{array}{l}\text { June } 8,1993 \\
\text { Secretarial Policy } \\
\text { Statement } \\
\text { (58 FR 33804-5) }\end{array}$ & Radiological Health and Safety Policy & DOE \\
\hline $\begin{array}{l}\text { March 24, } 1990 \\
\text { Toxicity } \\
\text { Characteristics } \\
\text { Revisions } \\
55 \text { FR } 11798 \\
\end{array}$ & $\begin{array}{l}\text { Hazardous Waste Management System, } \\
\text { Identification and Listing of Hazardous Waste }\end{array}$ & \\
\hline EPA 450/4-87-007 & Ambient Monitoring Guidelines for PSD & EPA \\
\hline $\begin{array}{l}\text { OSWER Directive } \\
9230.0-3 \mathrm{~B} \\
\end{array}$ & $\begin{array}{l}\text { Community Relations in Superfund: A } \\
\text { Handbook, Interim Version }\end{array}$ & EPA \\
\hline $\begin{array}{l}\text { OSWER Directive } \\
9355.3-01\end{array}$ & $\begin{array}{l}\text { Guidance for Conducting Remedial } \\
\text { Investigations and Feasibility Studies Under } \\
\text { CERCLA }\end{array}$ & EPA \\
\hline $\begin{array}{l}\text { Oklahoma } \\
\text { Administrative Code } \\
\text { (OAC), Title 165, } \\
\text { Chapter } 25\end{array}$ & Underground Storage Tank Regulations & $\begin{array}{l}\text { Oklahoma } \\
\text { Corporation } \\
\text { Commission }\end{array}$ \\
\hline
\end{tabular}




\begin{tabular}{|c|c|c|}
\hline \multicolumn{3}{|c|}{ 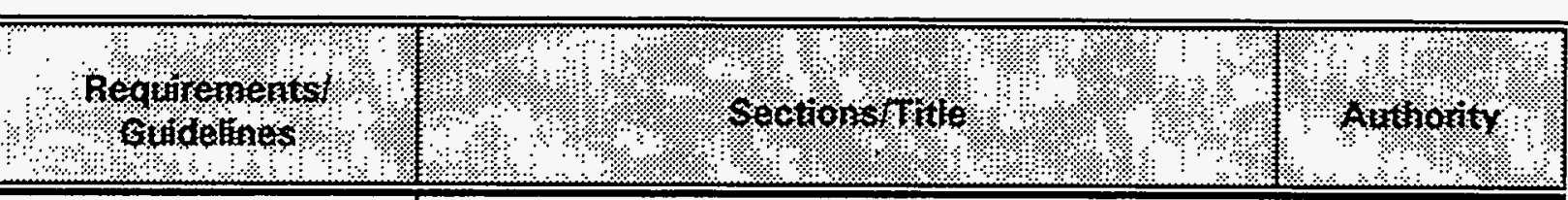 } \\
\hline $\begin{array}{l}\text { OAC, Title } 310, \\
\text { Chapter } 200\end{array}$ & Air Pollution Control Regulations & $\begin{array}{l}\text { Oklahoma } \\
\text { State } \\
\text { Department of } \\
\text { Health } \\
\text { (OSDH) } \\
\end{array}$ \\
\hline $\begin{array}{l}\text { OAC, Title } 310 \text {, } \\
\text { Chapter } 270\end{array}$ & $\begin{array}{l}\text { Rules and Regulations for Hazardous Waste } \\
\text { Management }\end{array}$ & OSDH \\
\hline $\begin{array}{l}\text { OAC, Title } 310 \text {, } \\
\text { Chapter } 330\end{array}$ & Public Water Supply Regulations & OSDH \\
\hline $\begin{array}{l}\text { OAC, Title } 310 \text {, } \\
\text { Chapter } 360\end{array}$ & $\begin{array}{l}\text { Solid Waste and Sludge Management } \\
\text { Regulations }\end{array}$ & OSDH \\
\hline $\begin{array}{l}\text { OAC, Title } 310, \\
\text { Chapter } 385\end{array}$ & Water Pollution Control Regulations & OSDH \\
\hline $\begin{array}{l}\text { OAC, Title 555, } \\
\text { Chapter } 10\end{array}$ & $\begin{array}{l}\text { Oklahoma Oil and Hazardous Substances } \\
\text { Pollution Contingency Plan }\end{array}$ & Various \\
\hline $\begin{array}{l}\text { OAC, Title } 785, \\
\text { Chapter } 40\end{array}$ & Pollution Remedies Regulations & $\begin{array}{c}\text { Oklahoma } \\
\text { Water } \\
\text { Resources } \\
\text { Board (OWRB) }\end{array}$ \\
\hline $\begin{array}{l}\text { OAC, Title } 785 \text {, } \\
\text { Chapter } 45\end{array}$ & Water Quality Standards & OWRB \\
\hline
\end{tabular}


Page intentionally blank 
APPENDIX G

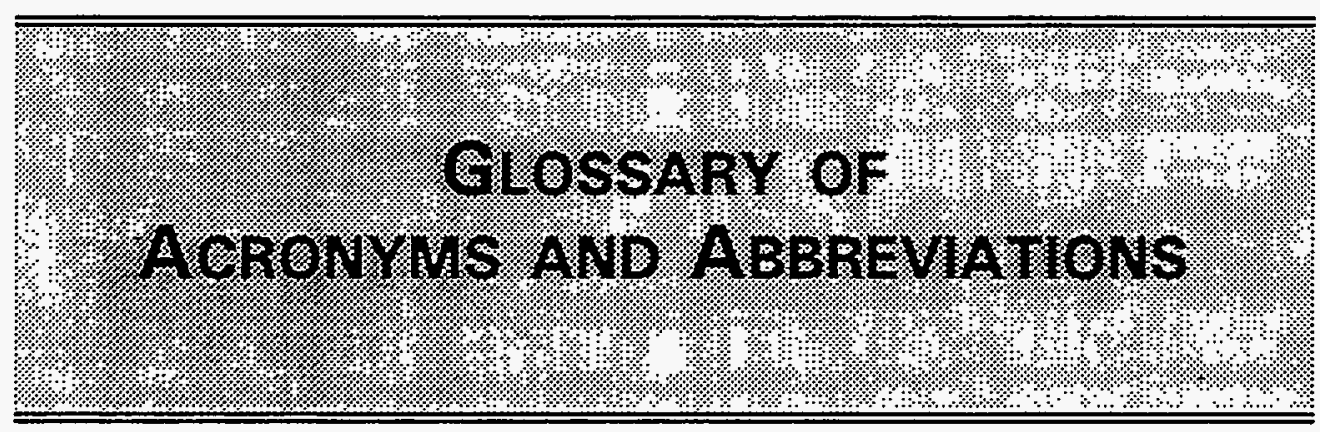


Page intentionally blank 


\section{GLOSSARY OF ACRONYMS AND ABBREVIATIONS}

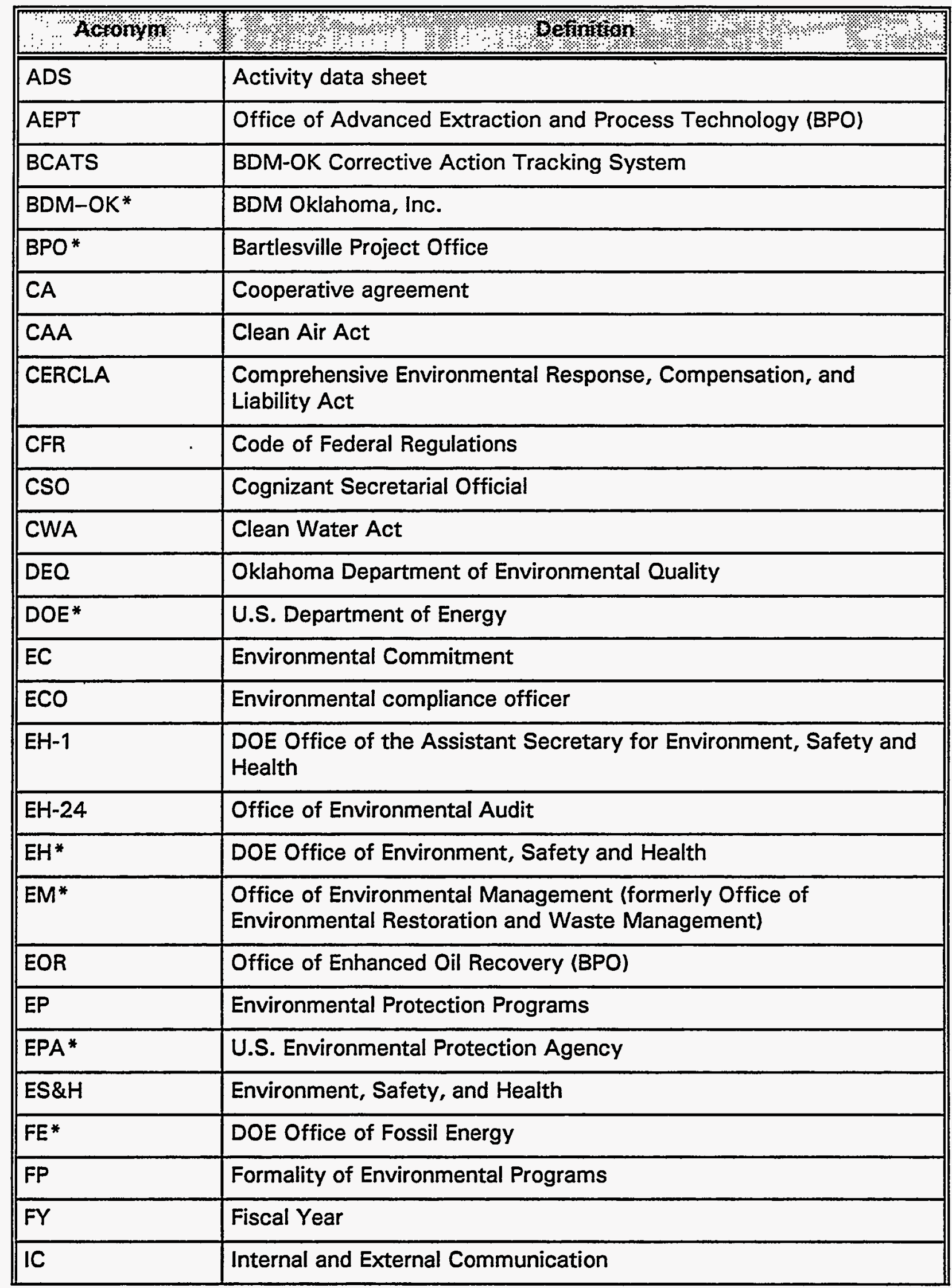


GLOSSARY OF ACRONYMS AND ABBREVIATIONS (continued)

\begin{tabular}{|c|c|}
\hline 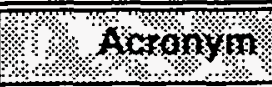 & 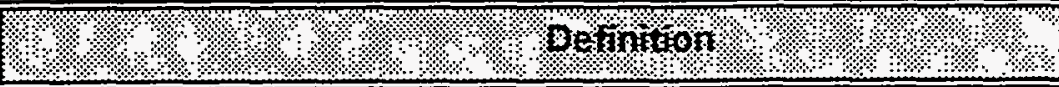 \\
\hline IDP & Individual Development Plan \\
\hline LAN & Local area network \\
\hline M\&O & Management and Operating \\
\hline METC & Morgantown Energy Technology Center \\
\hline MOA & Memorandum of Agreement \\
\hline NEPA & National Environmental Policy Act \\
\hline NESHAP & National Emission Standards for Hazardous Air Pollutants \\
\hline NORP & National Oil and Related Programs \\
\hline OS & Organizational Structure \\
\hline PA & Preliminary assessment \\
\hline PE & Program Evaluation, Reporting, and Corrective Action \\
\hline PETC* & Pittsburgh Energy Technology Center \\
\hline POC & Performance Objectives and Criteria \\
\hline QA/OC & Office of Quality Assurance/Quality Control (BPO) \\
\hline$Q A$ & Quality Assurance \\
\hline RCRA & Resource Conservation and Recovery Act \\
\hline RM & Environmental Planning and Risk Management \\
\hline SA & Self Assessment \\
\hline SARA & Superfund Amendments and Reauthorization Act \\
\hline SEN & Secretary of Energy Notice \\
\hline SOP & Standard operating procedure \\
\hline SPCC & Spill Prevention Control and Countermeasure \\
\hline SR & Staff Resources, Training, and Development \\
\hline TORIS & Office of Tertiary Oil Recovery information Systems (BPO) \\
\hline TTRS & Tiger Team Reporting System \\
\hline
\end{tabular}

-These commonly used acronyms are spelled out only on first reference in the report. All others are spelled out on first reference in each subsection. 